\title{
Challenges in the design of concentrator photovoltaic (CPV) modules to achieve highest efficiencies
}

\author{
M. Wiesenfarth, ${ }^{1, \text { a) }}$ I. Anton, ${ }^{2}$ and A. W. Bett ${ }^{1}$ \\ ${ }^{1}$ Fraunhofer Institute for Solar Energy Systems, ISE, Heidenhofstraße 2, 79110 Freiburg, Germany \\ ${ }^{2}$ Instituto de Energía Solar (IES), Universidad Politécnica de Madrid (UPM), Av. Complutense, 30 , \\ 28040 Madrid, Spain
}

(Received 1 July 2018; accepted 22 October 2018; published online 15 November 2018)

\begin{abstract}
Concentrator photovoltaics (CPV) is a special high efficiency system technology in the world of PV-technologies. The idea of CPV is to use optical light concentrators to increase the incident power on solar cells. The solar cell area is comparatively tiny, thus saving expensive semiconductor materials and allowing the use of more sophisticated and more costly multi-junction solar cells. The highest CPV module efficiency achieved is 38.9\%. This CPV module uses four-junction III-Vbased solar cells. Moreover, mini-modules have already achieved an efficiency of $43.4 \%$. The interaction between optics, cells, and layout of the module and tracker determines the overall field performance. Today, some utility scale CPV plants are installed. The CPV technology allows for many technical solutions for system designs and for optimizing performance while maintaining the economics. This paper will review the achievements and discuss the challenges for the CPV module technology and its components. We discuss the different components and the most important effects regarding the module design. Furthermore, we present the module designs that have shown the highest efficiencies. Published by AIP Publishing. https://doi.org/10.1063/1.5046752
\end{abstract}

\section{TABLE OF CONTENTS}

I. INTRODUCTION $\ldots \ldots \ldots \ldots \ldots \ldots \ldots \ldots$

II. COMPONENTS IN CPV AND SPECIFIC

DESIGN REQUIREMENTS ...............

A. Concentrator optics..................

1. Main characteristics of optics in a CPV module....................... 4

2. Primary concentrator optics (POE):

Reflective mirror optics .............

3. Primary concentrator optics (POE):

Refractive lens optics ..............

4. Secondary optical element (SOE) ......

B. Solar cell. .........................

1. Solar cell architectures ..............

2. Electrical design in the module: Interconnection of solar cells..........

3. Optical design and current distribution in the solar cell in the CPV module.....

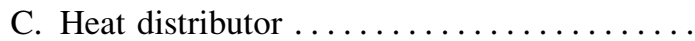

1. Passive heat distribution..............

2. Active heat distribution with dense arrays.........................

3. Thermal design aspects in the CPV module:

Size of solar cell and flux density and distribution .......................

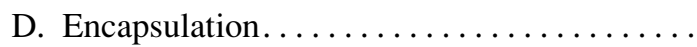

1. Designs for low module height and low focal distance ....................

E. Reliability .......................

${ }^{\text {a)} E l e c t r o n i c ~ m a i l: ~ m a i k e . w i e s e n f a r t h @ i s e . f r a u n h o f e r . d e ~}$
F. Novel module designs................ 17

1. Utilizing the diffuse irradiation........ 17

2. Micro-CPV .................. 17

III. SYSTEM AND FIELD PERFORMANCE ...... 17

A. Electrical performance ............ 17

B. Prediction of the power output ........ 18

C. Prediction of the energy yield and assessment of plant performance ........ 18

D. Maintenance incidence during operation of CPV plants ........................ 19

E. Long term stability-Durability ......... 19

IV. CONCLUSION .................. 20

\section{INTRODUCTION}

In concentrator photovoltaic (CPV) technology, solar radiation is concentrated on a small solar cell to reduce semiconductor area by means of an optical collector. Typically, the systems are separated into two categories: high concentration photovoltaic (HCPV) systems with concentration factors of $>300 \times$ using high efficiency multi-junction solar cells and low concentration photovoltaic systems (LCPV) with concentration factors of $>1 \times$ to $30 \times$ using silicon solar cells in adapted designs. In the latter technology, silicon solar cells are applied since the concentration level is not high enough to justify the use of more expensive multi-junction solar cells. While HCPV are based on point focus collectors, LCPV are typically linear systems concentrating the solar radiation in only one axis. As of the end of 2017, CPV systems with a cumulated capacity of $387 \mathrm{MW}$ were installed with the dominating share being HCPV systems (361 MW). To our knowledge, there are no commercial medium concentration systems (concentration factor between 30 and 300) currently developed. In Fig. 1, different commercial CPV systems are shown. In this paper, the 


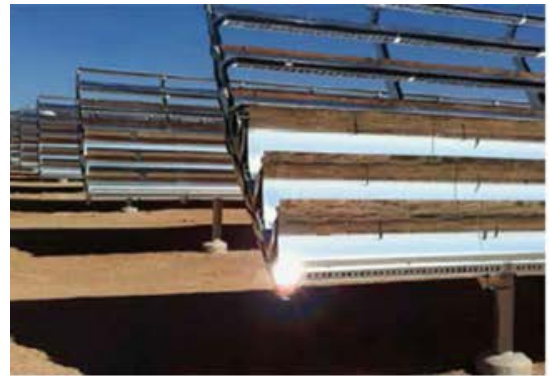

(a)

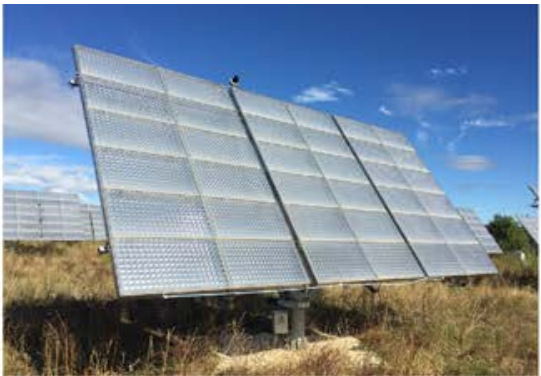

(b)

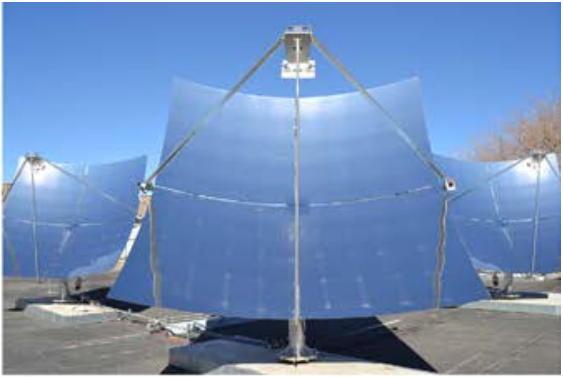

(c)

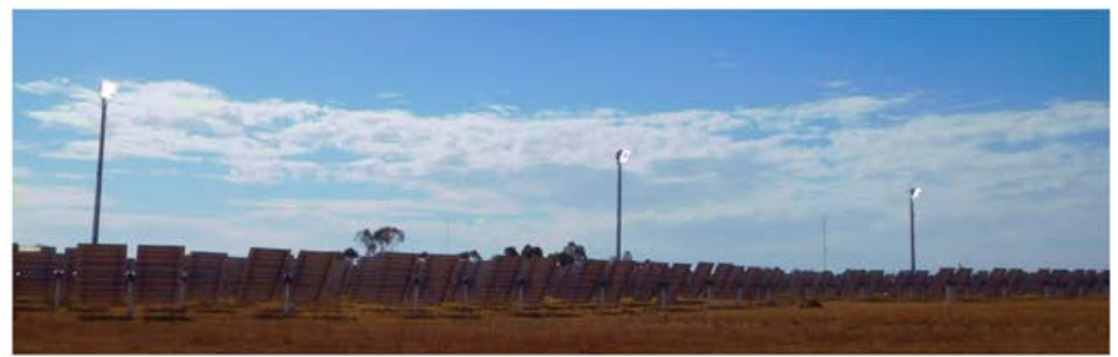

(d)

FIG. 1. Examples of commercial CPV systems: (a) low concentration system 7× CPV from SunPower Corporation, (b) lens based mirror system from SaintAugustin Canada Electric, Inc. (STACE), (c) Suncore Solar Power dish system, and (d) CPV tower from RayGen Resources Pty Ltd. Pictures are provided and used with permission from the companies. It is worth noting that SunPower developed a LCPV system with $7 \times$ (a) to enable faster growth in power plant applications. The system leveraged SunPower's silicon-based high-efficiency cells and tracker technology. However, additional progress in flat-plate PV cost reduction and performance moved the benchmark and created new opportunities, leading SunPower to change strategy to address the power plant market using a new-technology flat-plate module and tracker. The other companies (for the HCPV systems) shown are exploiting their own technologies and have announced further installations.

emphasis is on HCPV modules. However, the basic design principles need to be considered in all CPV systems even though the flux densities are lower in LCPV and medium concentration systems. This means, regarding the design principles, optical requirements, alignment, and mechanical tolerances, a linear system with a geometrical concentration level of $30 \times$ is equivalent to a point focus system of $900 \times$.

Superior efficiency and high cell cost were the ultimate motivation for developing CPV during the past few decades. Historically, the first lens based system Martin Marietta was demonstrated at Sandia laboratory in Arizona ${ }^{1}$ in the early 1980s, motivated by the high cost of the silicon cells at that time. Development efforts increased continuously. In the early 2000s, Amonix (now Arzon) together with the European partner Guascor Foton installed more than $3 \mathrm{MW}$ starting with a $100 \mathrm{~kW}$ installation at Glendale Airport, Arizona, ${ }^{2}$ using high efficiency silicon solar cells. ${ }^{3}$

One breakthrough for CPV technology took place around 2008 when multi-junction solar cells became available for the terrestrial market. At that time, the first large installations of different manufacturers using HCPV systems with multijunction solar cells were installed in Puertollano, Spain. The multi-junction solar cell consists of several pn-junctions in different bandgap materials. In this way, transmission and thermalization losses are reduced and high electrical efficiencies are possible. Concentration of solar radiation raises the efficiency additionally, as the open circuit voltage increases due to higher quasi-Fermi level separation. Multi-junction solar cells achieved electrical efficiencies of $46 \%$ under $508 \times$ concentrated illumination (solar cell with four pn-junctions). ${ }^{4}$ Introducing this kind of solar cell with the same solar cell structure but adapted grid design to be used in modules resulted in the highest electrical efficiencies measured for a CPV module with $38.9 \%$ under concentrator standard test conditions (CSTCs). ${ }^{5}$ Today, the CPV technology is mature with many modules certified to International Electrotechnical Commission (IEC) $62108^{6}$ to prove reliability. Since 2008, the installation in Puertollano has been operated. The IEC 62108-certified lens-based systems with a capacity of 600 $\mathrm{kW}_{\mathrm{p}}$ showed no significant degradation. ${ }^{7,8}$ The largest utility scale CPV installations so far-all based on multi-junction solar cells-were installed in Golmud, China, $138 \mathrm{MW}_{\mathrm{p}}(58$ $\mathrm{MW}_{\mathrm{p}}$ in 2012 and $79.8 \mathrm{MW}_{\mathrm{p}}$ in 2013), ${ }^{9-11}$ in Touwsrivier, South Africa, $44.19 \mathrm{MW}_{\mathrm{p}}$ (2014), ${ }^{12}$ in Alamosa, USA, 35.3 $\mathrm{MW}_{\mathrm{p}}$ (2012), ${ }^{13}$ and in Delingha City, China, $12 \mathrm{MW}$ (2016). ${ }^{11}$

Another key innovation for CPV was the development of the technology for silicone-on-glass (SoG) Fresnel lenses. The idea of a thin silicone layer in which the Fresnel structure of a lens is molded and which is attached to a mechanically stable glass plate was already published in $1979^{14}$ by Lorenzo and Sala from University Politécnica de Madrid. In the early 2000s, a process for mass manufacturing of large arrays was developed at Fraunhofer institute for Solar Energy Systems ISE together with the Ioffe Institute in St. Petersburg. ${ }^{15}$ The technology was applied to fabricate CPV modules which are known as the FLATCON ${ }^{\circledR}$ technology. FLATCON $^{\circledR}$ is the abbreviation for Frensel Lens All glass Tandem cell CONcentrator module. The SoG technology gained market 
module

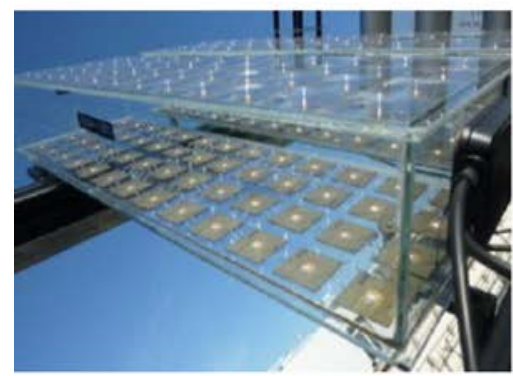

system

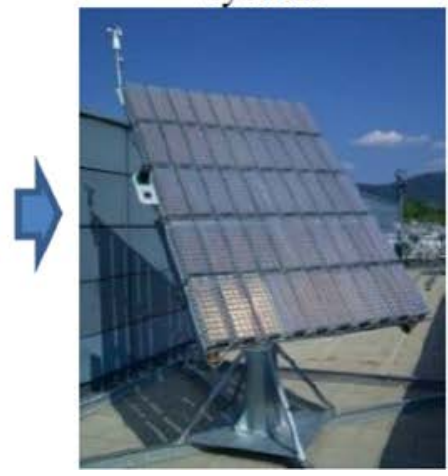

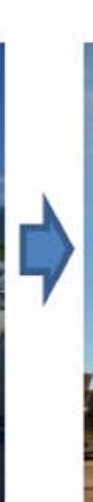

plant

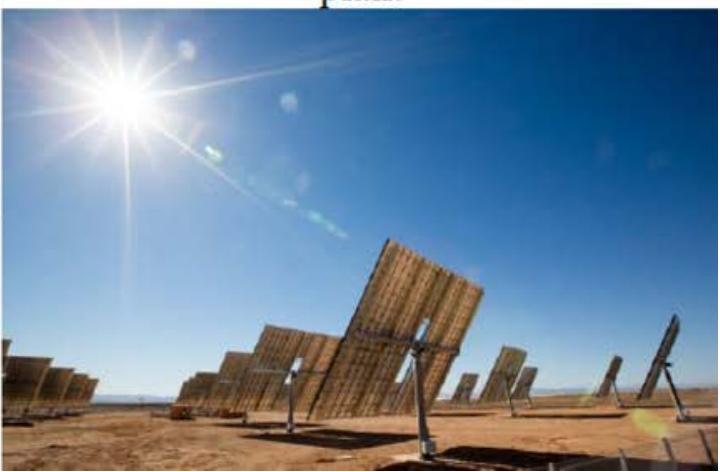

FIG. 2. From the module to the CPV power plant, several modules are assembled onto a tracker to form a CPV system. In the power plant, many systems are combined. The plant also comprises land, inverters, wiring, and grid connection. Here, the FLATCON ${ }^{\circledR}$ module and a 1 kW CPV system with the FLATCON ${ }^{\circledR}$ technology installed in 2006 are shown. For the plant, the installation from Sumitomo in Ouarzazate, Morocco ${ }^{20}$ that started operation in 2016 is shown (plant pictured with permission from Sumitomo).

shares and is used in the large installations that were installed recently (e.g., Golmud ${ }^{16}$ and Touwsrivier ${ }^{17,18}$ ).

When discussing CPV technology, it is recommended to introduce different technology levels. In this paper, the distinction is presented in Fig. 2: we distinguish between the module, the single system, and the power plant. The module consists of many solar cell receivers and housing with electrical connections. The single system consists of several modules installed on a highly accurate two axis tracker which follows the course of the sun. High accuracy trackers for HCPV systems with $0.1^{\circ}$ to $1^{\circ}$ depending on the acceptance angle of the module are required. ${ }^{19}$ The tracker also requires the unit for tracker control and infrastructure with the foundation. Many single CPV systems are combined in the CPV plant that is connected to the grid. The electricity generation of the plant obviously depends on the location, its solar resource, and the plant size but also on the performance and availability of the systems that, in turn, strongly depend on the procedures for operation and maintenance (O\&M). On all levels, low costs and reliable performance are required.

For the design of CPV modules, several components need to be configured for the best performance. Following the terminology defined in IEC 62108 and shown in Fig. 3, a CPV module consists of the receiver (solar cell with an optional secondary optical element (SOE), heat distributor, and electrical contacts) and the optical array. In case of a large dish mirror system or a solar tower system, the receiver with the solar cell is decoupled from the optics. Therefore, the solar cell subsystem of the full receiver combined with an optical concentrator and tracker is defined as the assembly. In the module or assembly, the concentrator optics focuses solar radiation onto the solar cell. The solar cell generates electrical energy. The energy that is not converted is lost, the majority dissipated as heat. This thermal energy is transferred either passively by conduction to a large area where it is transferred by convection and thermal radiation to the environment or actively by transfer to a cooling fluid. Thus, thorough thermal management in a CPV module is essential. The solar cells are electrically interconnected and additional components like bypass diodes are included in the module. Finally, the solar cells are protected from the environment by encapsulation or housing.

In this work, we focus on the challenges in designing modules and subcomponents. The CPV-specific design requirements for the different components of a CPV module are reviewed. The main design aspects and the highest performance module designs are presented. Finally, we briefly cover field experience of power plants in the last section.

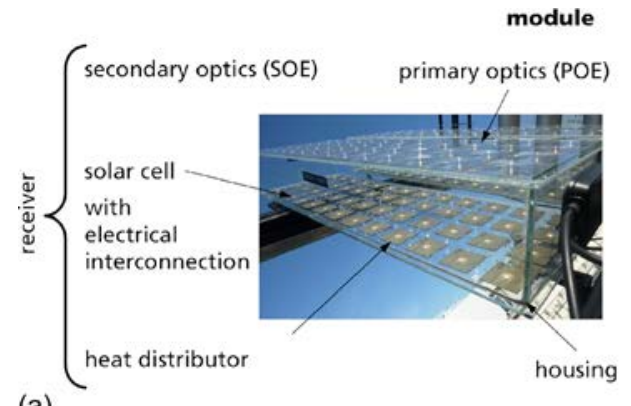

(a)

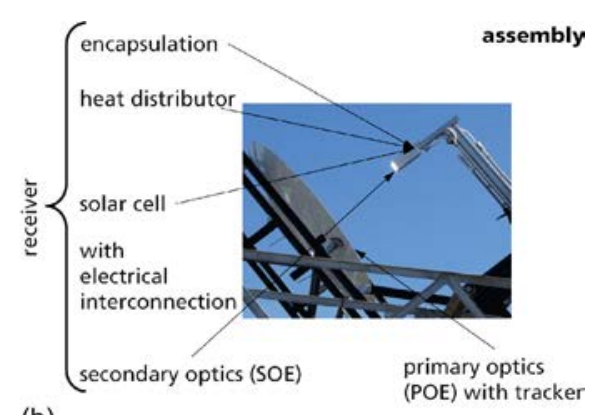

(b)

FIG. 3. Terminology of a CPV module based on several optics in an array and small solar cells (a) and an assembly where the primary optics (dish or heliostats) is decoupled from the receiver (b). The receiver is composed of the solar cell with electrical contacts, the heat distributor, and if present the secondary optics. Together with the primary optics (lens or mirror), they build the module or assembly. The module is housed, whereas for the assembly the encapsulation is part of the receiver. In a CPV module, all component designs need to be matched to result in a high performance module design. 


\section{COMPONENTS IN CPV AND SPECIFIC DESIGN REQUIREMENTS}

\section{A. Concentrator optics}

\section{Main characteristics of optics in a CPV module}

The optical efficiency $\eta_{o p t}$ is the most important figure of merit of an optical component as it is the measure of how much of the solar power incident on the optics aperture $P_{\text {aperture }}$ is transferred to the cell area $P_{\text {flux }, \text { cell }}$

$$
\eta_{\text {opt }}=\frac{P_{\text {flux }, \text { cell }}}{P_{\text {aperture }}} .
$$

The optical losses in Fresnel lenses are transmission losses due to absorption and reflection and geometrical losses (i.e., losses due to the Fresnel structures shape inaccuracy and scattering losses). Furthermore, dispersion losses can be significant, i.e., refractive systems suffer from chromatic aberration. In mirror optics, there is little loss due to wavelengthdependent dispersion and no draft angle loss. However, there are also reflection and geometrical losses and, additionally, shading by the solar cell and heat distributor or in specific configurations as in a Cassegrain assembly shading by secondary optics. Further reflection losses occur if a cover glass protects the mirror optics. Recently, the standard IEC 62989 Technical Specification (TS) Primary Optics was published $(08 / 03 / 2018)^{21}$ providing standard procedures for the qualification and characterization of primary optics.

Further important design criteria in the context of a CPV module are shown in Fig. 4: first, the focal distance $\mathrm{f}$ not only defines the module height but also influences the optical design, then the half opening angle $\theta$ as the angle to the optical axis at which the rays can maximally hit the solar cell.

An important figure for module specification is the geometrical concentration $c_{g e o}$. It is defined by the fraction of the aperture area $A_{\text {aperture }}$ and the designated area of the solar

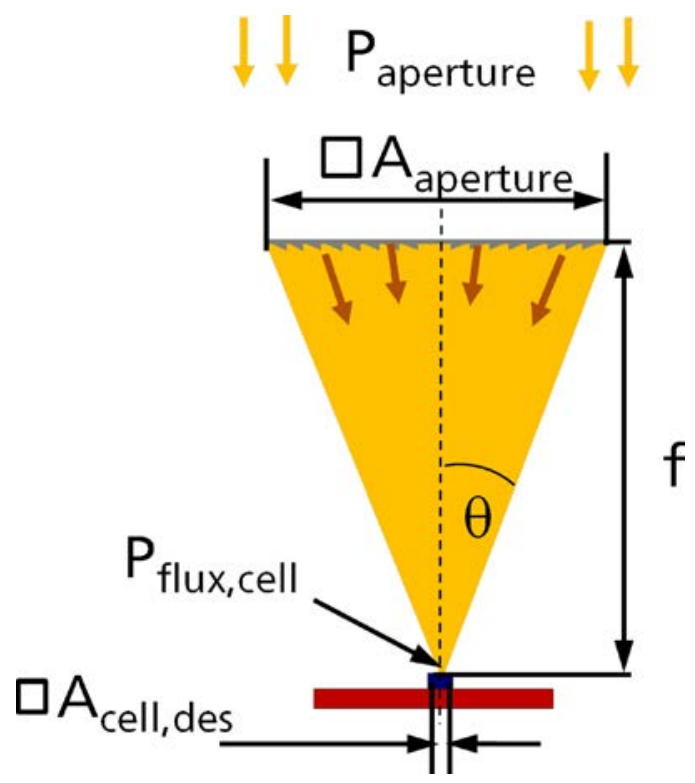

FIG. 4. Defining geometrical characteristics in a lens-based CPV module: focal distance $\mathrm{f}$, half opening angle $\theta$, and in this case square areas. Also, the position of input for solar power $P_{\text {aperture }}$ and $P_{\text {flux,cell }}$ is indicated. cell $A_{\text {cell,des }}$ where the designated area is the illuminated area of the solar cell within the bus bars

$$
c_{\text {geo }}=\frac{A_{\text {aperture }}}{A_{\text {cell, des }}} .
$$

Another major characteristic of a CPV module is the acceptance angle $\alpha$. The acceptance angle $\alpha_{90 \%}$ is defined as the angle of module inclination towards the sun where $90 \%$ of the modulés power is generated. The $100 \%$ power reference is obtained for the exact alignment of the module towards the sun. The $90 \%$ target is commonly used, but any other target can be defined.

There is a trade-off between both characteristics $\left(c_{\text {geo }}\right.$ and $\alpha$ ) that can be expressed in the concentration acceptance product $(\mathrm{CAP})^{22}$ as defined in the following equation:

$$
C A P=\sqrt{c_{g e o}} \sin (\alpha) .
$$

The $C A P$ is limited by thermodynamics, according to the conservation of etendue ${ }^{23}$

$$
c_{\text {max }} n_{\text {in }}^{2} \sin _{\text {in }}^{2}\left(\theta_{\text {in }}\right)=n_{\text {out }}^{2} \sin ^{2}\left(\theta_{\text {out }}\right),
$$

where $\theta_{\text {in }}$ and $\theta_{\text {out }}$ are the maximum angles of the input (light source) and output (concentrated light) beams and $n_{i n}$ and $n_{\text {out }}$ are the refractive indices of the input medium (air) and output medium (between optics and cell).

With the maximum angle of radiation on the solar cell of $\theta_{\text {out }}=90^{\circ}$ and the index of refraction of the input medium $n_{i n}=1$ for air, the maximum theoretical acceptance angle $\theta_{\text {in }}=\alpha_{100 \%}$ can be calculated from the maximum CAP achievable which corresponds to the refraction index between optics and solar cell $n_{\text {out }}$, see also $\left(C A P_{\max }=n_{\text {out }}\right) .{ }^{24}$ This theoretical value can only be approached with complex optical designs of several optical surfaces, while practical designs are far from that value. The maximum acceptance angles versus concentration for different refractive indices and values that were measured on real systems are shown in Fig. 5.

Concentrator optics are distinguished into imaging and non-imaging optics. Imaging point focus optics display a miniaturized image of the sun onto the solar cell. Examples of imaging optics are aspheric plano-convex lens designs (including Fresnel lenses) or paraboloidal mirrors. Nonimaging or anidolic optics do not form an image of the source but focus on the optimal power transmission, which provides an additional degree of freedom and requires designing the shape of the surfaces of the optics. As a result, the form of the source can be adapted, for example, from a circular to rectangular target flux distribution. The optical design for nonimaging optics is defined by the edge-ray principle ${ }^{43}$ with the design objective that rays coming from the edges of the source are focused towards the edge of the solar cell. In this way, all the rays in between will hit the target. Non-imaging optical elements may work by total internal reflection as in a compound parabolic concentrator (CPC) or kaleidoscope homogenizer. Designs based on Köhler integration have achieved the highest $C A P$ values in CPV optical systems based on primary lenses ${ }^{44}$ such as the LPI Fresnel-Köhler (FK) concentrator consisting of four units in an array. ${ }^{22} \mathrm{~A}$ 


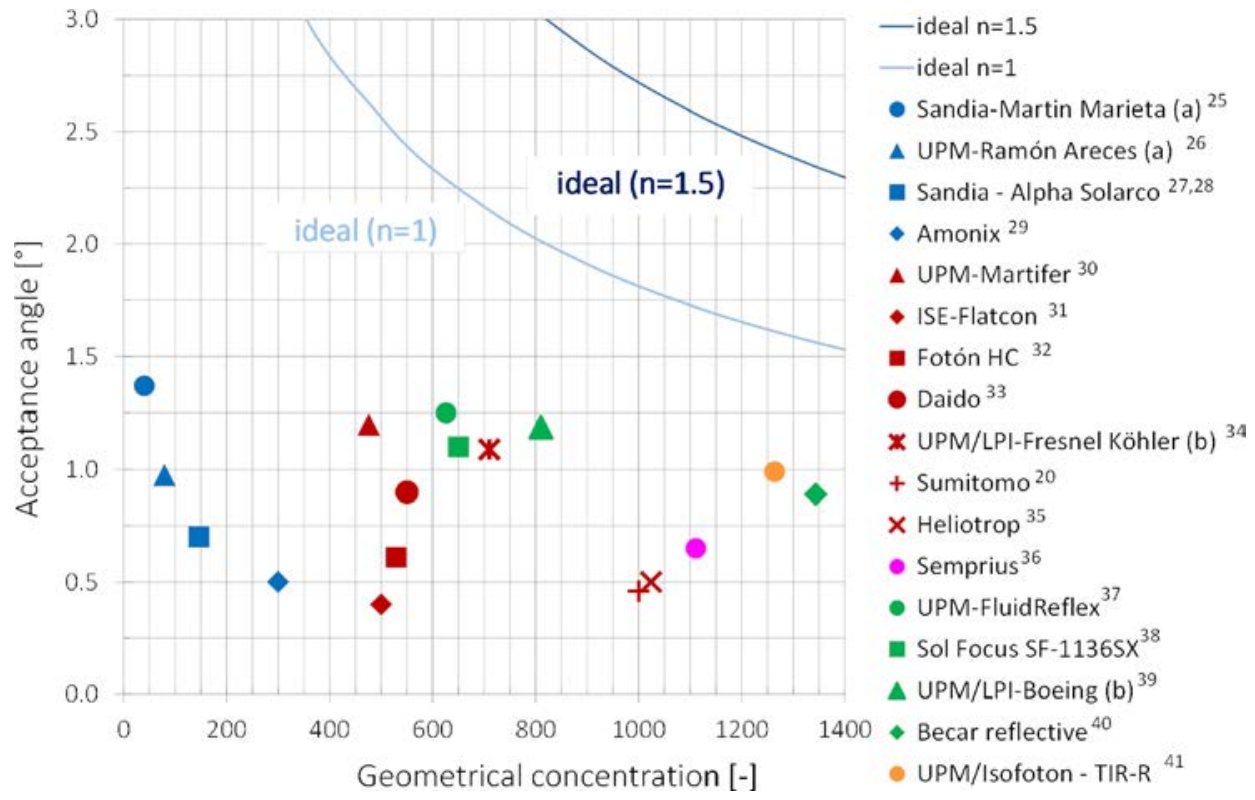

FIG. 5. Geometrical concentration $c_{\text {geo }}$ and acceptance angle $\alpha_{90 \%}$ of several concentrating optics. Values depicted in the graph were either reported at the references given or measured at the IES-UPM laboratories. The color code is as follows: blue, systems including silicon solar cells and Fresnel lenses (all the others are based on multi-junction solar cells); red, systems based on Fresnel lenses as primary optics; green, systems using reflective primary optics; pink, micro-CPV system based on refractive primary optics; and orange, two stage optics with primary stage working by total internal reflection (TIR). ${ }^{20,25-41}$ The continuous lines represent the theoretical limit of the attainable concentration acceptance angle product $(C A P)$ achievable according to the conservation of etendue, for a system where the cell is surrounded by air $\left(n_{\text {out }}=1\right)$ or a medium whose refractive index is $n_{\text {out }}=1.5$, i.e., glass or silicone. (a) As for the early systems, measured acceptance angle has not been reported, and a value for the CAP equal to the most similar technology (Amonix) was assumed. (b) For these concentrators, only acceptance angle for the elementary unit was reported. Thus, $90 \%$ of that value has been assumed to be attainable for the entire module. Graph reproduced with permission from M. Victoria Pérez, "New concepts and techniques for the development of high-efficiency concentrating photovoltaic modules," Ph.D. thesis (E.T.S.I. Telecomunicación, UPM, 2014). ${ }^{42}$

Köhler integrator forms the image of an object (in CPV, the light incident upon the aperture of the primary optics) upon the output. Since the entrance of the primary optics receives uniform irradiance from the sun, its image on the cell is also a uniform concentrated light spot, reducing the impact of chromatic aberration. As described by Chayet et al. in Ref. 45, the possibility of defining the flux distribution by non-imaging optics is especially advantageous in primary mirror optics with a dense array. The flux on receiver with the solar cells is uniform which simplifies electrical series interconnection of solar cells without the need for secondary optics.

\section{Primary concentrator optics (POE): Reflective mirror optics}

Reflective mirrors do not show chromatic aberration and high optical efficiencies are achieved if the spectral reflectivity is high for a wide wavelength range. In Fig. 6, examples for measured spectral reflectivity on plane surfaces for different materials are shown and for comparison the solar reference spectrum ASTM G173-3, AM1.5d.

Silver mirrors are made by coating glasses, metals, or polymers. For so called first mirrors-the coating is applied on a substrate (not superstrate) - the surface has to be protected from humidity and mechanical stress leading to corrosion (here $\mathrm{SiO}_{\mathrm{x}}$ coating). In the example of Fig. 6, the silver coated shows the best optical performance with a solar spectrum weighted reflectivity of $94.6 \%$. Aluminum-based (polished, anodized $)^{46}$ mirrors reveal $90.2 \%$ weighted reflectivity.
Point focus mirror modules with passive heat distribution are assembled in an on-axis, asymmetrical or Cassegrain mirror arrangement. In the Cassegrain concept, parabolic and hyperbolic mirrors are combined. Different commercial and prototype modules are presented in Refs. 37 and 47-49 with the largest deployment by SolFocus. ${ }^{16}$ The Cassegrain concept uses two optical surfaces to redirect the light towards the rearplane and has the advantage of low module

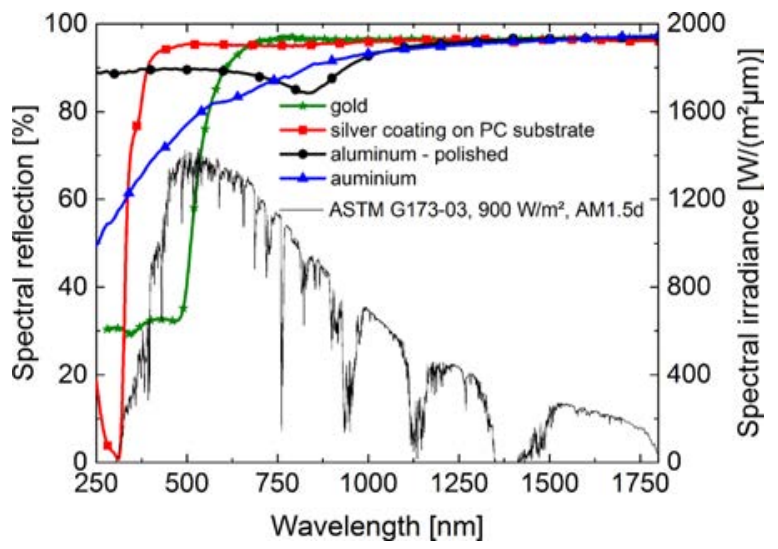

FIG. 6. Spectral reflectance for different materials. The silver coated sample on a polycarbonate $(\mathrm{PC})$ substrate has a protective $\mathrm{SiO}_{\mathrm{x}}$ coating. The aluminum alloy consists of $99.9 \%$ aluminum. The average reflectivity between 280 and $1800 \mathrm{~nm}$ was weighted with the relative power that is available for the respective wavelength in the standard spectrum ASTM G173-3, AM1.5d. The weighted reflectivity for the silver coated sample is $94.6 \%$, for the sample of polished aluminum is $90.2 \%$, and aluminum sample is $85.7 \%$. The data are examples carried out at Fraunhofer ISE to illustrate the wavelength dependent reflection of the different materials. 
heights. In the on-axis arrangement (only one reflective surface), the solar cell and heat distributor are placed in the focal point of the mirror optics at the aperture plane, reducing the optical losses (less optical surfaces used) but shading the mirror. Thus, small-sized mirrors (e.g., $<200 \mathrm{~mm}^{2}$ ) and correspondingly small-sized solar cells are recommended. ${ }^{50}$ An alternative proposed uses an optical fluid to enhance both the optical properties and the heat dissipation. ${ }^{37}$

Large parabolic mirrors and heliostats are used in other CPV systems based on reflective optics. Paraboloidal dishes have aperture areas of around $1 \mathrm{~m}^{2}$ (Ref. 51) up to $400 \mathrm{~m}^{2}{ }^{52} \mathrm{~A}$ heliostat field is used in CPV tower systems (see also Sec. II C 2). The two-axis tracked heliostats have a large area of several square meters from $15 \mathrm{~m}^{2}$ (Refs. 53 and 54) to $>100$ $\mathrm{m}^{2}{ }^{55}$ They are either planar or paraboloidal in shape or consist of tilt and aligned segments to increase the concentration on the receiver area. Mini heliostats with an area of approximately $1 \mathrm{~m}^{2}$ (Ref. 56) are investigated to decrease requirements for mechanical stability. The heliostats are interconnected with wires over the heliostat field for controlling. Mechanically combining several trackers reduces the quantity for tracking controls or motors required. In Ref. 53 by Lasich et al., autonomous heliostats with a separate control for each mirror are proposed. If they are solar powered, even wiring between the heliostats can be omitted. The heliostat field layout needs to be optimized in respect to costs, optical losses, and losses due to shading and blocking between mirrors. ${ }^{57}$ Because of astigmatism and cosine losses, the larger the distance between optics and receiver at the tower is, the higher the optical losses are. This is why smaller heliostat fields have higher optical efficiency. In CPV, small fields and scalable installation sizes with single tower systems or a field of towers with electrical power per tower in the range of few hundreds of Watts to few Megawatts ${ }^{53,58}$ are feasible. In comparison, in concentrator solar power (CSP), the thermal capacity of the receivers is usually between 10 and 200 MW (Ref. 59) as, for example, in the Ivanpah Solar Electric Generating System (ISEGS) with rated capacity of $390 \mathrm{MW}$ for the three towers. ${ }^{54}$ The reason for the large capacities is that it is more effective in terms of costs and efficiency for the electrical generator in the tower. This is not required in $\mathrm{CPV}$ where the sub receivers can be arranged modularly.

\section{Primary concentrator optics (POE): Refractive lens optics}

In CPV, primary lens optics usually consist of several lenses with single unit areas of $4 \mathrm{~cm}^{2}$ (Ref. 60) to $1000 \mathrm{~cm}^{2}$ (Ref. 61) that are arranged in an array. The parallel manufacturing of several units shaping an array or parquet is a distinguishing feature of primary refractive optics and ultimately has a significant advantage in terms of costs. In principle, full-glass lenses are mechanically stable with high transparency. However, cost effective manufacturing on large areas and arrays is a challenge. Therefore, Fresnel lens structures are introduced to reduce material and weight. The losses should be minimized, i.e., low draft angles and low tip roundings are required. This is hardly achievable in a glass molding manufacturing process.

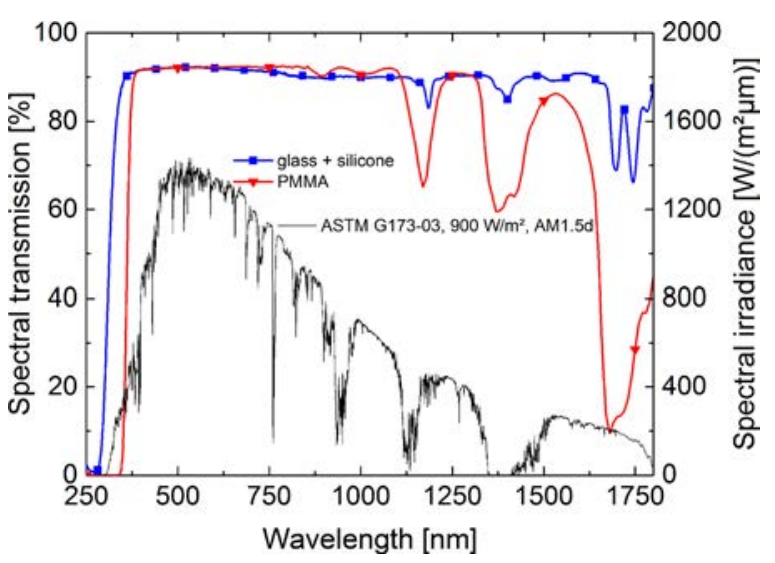

FIG. 7. Spectral transmission for different transparent materials. $4 \mathrm{~mm}$ thick glass with a $0.5 \mathrm{~mm}$ silicone layer was measured [no anti-reflection coating (ARC) was applied] at Fraunhofer ISE. The PMMA sample is PLEXIGLAS ${ }^{\circledR}$ Solar IM20 with $3.91 \mathrm{~mm}$ thickness. The measurement data were provided by Evonik. Introducing an anti-reflection coating could decrease the absolute reflection losses by about $4 \%$. To indicate the available solar resource for the respective wavelength, the reference spectrum ASTM G173-3, AM1.5d is shown in black.

Therefore, either polymethyl methacrylate (PMMA) or silicone (in SoG technology) is used as a material to form the Fresnel structures.

In Fig. 7, the spectral transmission is shown for a glasssilicone sample and a PMMA sample. For PMMA, dips in the high wavelength region are clearly visible. These spectral dips are critical if current matched multi-junction solar cells are used. For example, van Riesen et al. describe in Ref. 5 the impact on a four junction solar cell where the bottom junction absorbs above $1120 \mathrm{~nm}$ (i.e., below the energy bandgap of $1.1 \mathrm{eV}$ for the third junction); there, the first dip just starts. In the investigated solar cell, 12\% lower current is generated in this bottom junction due to transmission losses of PMMA. However, the SoG material also shows slight dips in the high wavelength region. The depth of the dip depends on the thickness of the silicone layer. This means in any material chosen, the transmission function of the primary optics needs to be considered when solar cell architectures for CPV modules are designed.

PMMA lenses are manufactured using a plastic molding process. $^{24,62} \mathrm{UV}$ stability was one of the major concerns for that technology as yellowing can occur. ${ }^{63}$ However, with the right material choice, PMMA lenses proved to be stable with only moderate degradation. ${ }^{64,65}$ With the manufacturing process of injection molding, it is possible to manufacture curved surfaces. A specific dome lens design was developed by Araki et al. ${ }^{66,67}$ With the dome shape non-imaging lens, chromatic aberration is reduced and high geometrical concentration factors can be achieved. In addition, the focal distance (module height) can be reduced. Another approach is proposed by Panasonic in Ref. 68. The lenses with the dome shape are directly attached to small solar cells $(0.5 \mu \mathrm{m} \times 0.5 \mu \mathrm{m})$ resulting also in a very thin module of $20 \mathrm{~mm}$.

As already described in the Introduction, most of the module manufacturers use silicone-on-glass (SoG) lenses. The glass superstrate is mechanically stable, resistant to UV radiation, and easy to clean. Even though injection molding 
has been used, ${ }^{62}$ today the SoG lenses are manufactured using a casting process. ${ }^{69}$

It is important to take into account that the optical efficiency of specifically SoG lenses changes with temperature. As shown by Schult et al. in Ref. 70, this is due to the change of the refractive index with temperature combined with deformation of the shape of the Fresnel facets due to the different thermal expansion of silicone and glass. The effect has been experimentally investigated in Refs. 71-73. To overcome this, an adapted Fresnel lens design suitable for a higher temperature range has been developed. ${ }^{74}$ The design considers the expected deformation due to thermal expansion effects. It was shown, for monochromatic light of $622 \mathrm{~nm}$, that with the improved Fresnel lens, the optical efficiency differs by $0.6 \%$ abs between 30 and $40{ }^{\circ} \mathrm{C}$, whereas the conventional SoG lens by $1.8 \%$ abs. For a wider temperature range, the difference becomes even more distinct. In the temperature range between 10 and $60^{\circ} \mathrm{C}$, a variation of optical efficiency of $3.1 \%$ abs for the improved design versus $11.6 \%$ abs for the conventional design was measured. For the standard spectrum AM1.5d, the average improvement for the new Fresnel lens is $3 \%$ rel. In Fig. 8, the measured and simulated monochromatic optical efficiencies are shown for different lens temperatures.

Despite other important parameters discussed, the yearly energy yield is the figure of merit for a CPV system. As discussed, the transfer function and the overall performance of the primary optics must be carefully investigated, since the spectrum of the sun changes over the course of a day and year and varies for different locations. Hornung et al. ${ }^{76}$ investigated the yearly energy generation for different locations considering modules with PMMA and SoG lenses and lattice-matched (LM) triple-junction solar cells. It was shown that under design conditions, the optical efficiency of modules with SoG lenses was slightly higher by an average $1.2 \%_{\text {rel }}$. Even so, at the CPV locations Blida in Algeria,

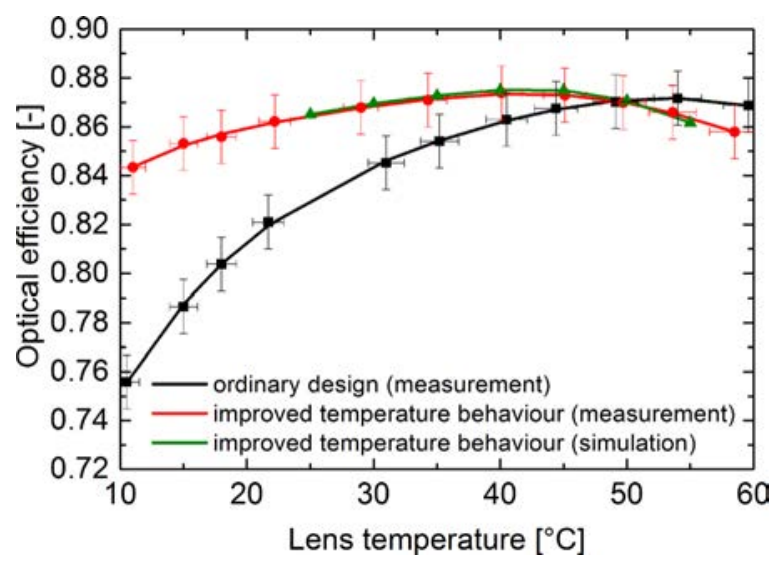

FIG. 8. Optical efficiencies for simulated and measured Fresnel lenses for different lens temperatures. The optical efficiency is reduced for high and low lens temperatures due to changes in refractive index and thermal expansion of the Fresnel structure. An ordinary lens design is compared to an improved SoG Fresnel lens design that shows a significant reduction in optical losses with temperature. Diagram according to Refs. 74 and 75 reproduced with permission from T. D. Hornung, "Ein- und mehrstufige optische Konzentratoren für photovoltaische Anwendungen," Ph.D. thesis (AlbertLudwigs-Universität, 2013).
Boulder in Colorado, USA, El Arenosillo in Spain and Sede Boker in Israel, the losses due to ambient temperature were lower for modules with PMMA lenses by $1 \%$ abs compared to a SoG Fresnel lens where the losses are roughly twice as high.

One of the major drawbacks of lenses is the loss due to chromatic aberration, caused by the wavelength dependency of the refractive index. Since refractive index varies both with temperature and wavelength, both effects must be consider as a whole: chromatic aberration produces a spatial separation of the wavelengths at the focal point and temperature variation changes the effective focal distance for each wavelength. ${ }^{72,77}$ In standard glass optics, achromatic doublet lenses have been developed. ${ }^{78}$ Recently, an achromatic Fresnel lens made of a laminate out of PMMA and polycarbonate (PC) was proposed by Languy et al. ${ }^{79}$ for a Fresnel lens. Vallerotto et al. ${ }^{80}$ presented an achromatic Fresnel lens structure which consists of a bifacial Fresnel lens made of PC or PMMA laminated to a glass substrate with silicone or ethylene-vinyl acetate (EVA). First promising experimental results were presented in Ref. 81 proving slightly higher tolerance to cell-lens distance between achromatic lenses and SoG lenses as well as lower changes for the spot diameter for the achromatic lens for varying temperature.

\section{Secondary optical element (SOE)}

Secondary optical elements (SOE) are introduced in CPV technology to increase concentration, acceptance angle, or homogenization of flux distribution. The effective concentration at the exit of the SOE has average values typically between 300 and 1100 suns but can reach peaks of several times the average. The coupling between the SOE and the cell is a critical design point to ensure performance and above all, the long term reliability of the CPV system. SOEs increase not only angular tolerance but they may also reduce cell electrical losses and improve fill factor (FF) by improving the flux uniformity, ${ }^{82,83}$ reducing impact and losses caused by the chromatic effect of refractive primary optics in multi-junction cells, ${ }^{84}$ and desensitizing the cell structure and design to focal distance and, consequently, to ambient temperature variations. ${ }^{77}$

Reflective SOEs have a conical ${ }^{85}$ or truncated pyramid shape. They are used to increase the concentration including usage of spilled light or acceptance angle. When they only capture spilled light or increase the acceptance angle, the reflective SOEs have the advantage of usually not being placed in the course of the concentrated light beam (or only a small part of the beam is reflected) and therefore they do not contribute with additional significant optical losses during on-axis operation. There are no absorption losses and thus higher optical efficiencies can be achieved for refractive SOEs. ${ }^{86}$ In addition, in case of failure of the SOE (e.g., if it falls off), it does not mean that the module is destroyed but only power output and angular tolerance decrease.

Solid SOEs consist of transparent materials with a higher refractive index than air (e.g., glass or silicone). Consequently, refractive SOEs lead to higher CAP values 
than reflective ones. Spherical or conical shapes are usually used to increase acceptance angle or capture spilled light. In Ref. 87, Menard et al. propose a ball-shaped lens that is used to increase the acceptance angle, homogenize the flux distribution and is easy to manufacture due to its regular shape. To combine different design objectives like increasing the concentration and acceptance angle, dome shaped SOEs are proposed in Refs. 88 and 89. In Ref. 90, flux uniformity and acceptance angle were investigated for half-egg, kaleidoscope and domed kaleidoscopic SOEs. It is shown that the highest optical efficiency and acceptance angle can be achieved for the domed kaleidoscope with slightly lower uniformity at $0.5^{\circ}$ than the half-egg. Other refractive designs are DTIR (dielectric total internal reflection) designs ${ }^{91}$ or Köhler integrators. $^{22}$

Reflective or refractive compound parabolic concentrators $(\mathrm{CPCs})^{23,90}$ or kaleidoscope ${ }^{66}$ shaped SOEs are introduced to homogenize the flux distribution and to increase the CAP. ${ }^{92}$ An example of a reflective Kaleidoscopic secondary optic to get uniform flux distribution on the solar cell or receiver is shown for a dense array by Helmers et al. in Ref. 93. Uniform illumination is required as difference in flux intensity results in different currents in the cells. One approach is to adapt the interconnection scheme of the solar cell's need to the flux profile. ${ }^{94}$ However, the flux profile is also influenced by non-constant or predictable factors like circumsolar radiation (CSR), manufacturing tolerances, and tracking errors. In this way, the SOE is beneficial.

In Ref. 86 by Victoria et al., reflective conical, reflective pyramid, refractive CPC, and two dome shaped SOE designs are compared. It was concluded that the shape and choice of material depend on the design objectives, so there is no general recommendation regarding the best design. In Fig. 9, examples for reflective and refractive secondary optical elements are shown that were also investigated experimentally at Fraunhofer ISE.

Reflective SOEs are manufactured by bending or deep drawing of metal sheets. Surface treatment such as anodizing, polishing of aluminum, or application of a silver layer increases the reflectivity (Fig. 6).

For refractive SOEs, high transparent and UV-stable materials are required as they are solid and are exposed to the concentrated radiation. The choices of material are silicones, ${ }^{89,98}$ glass molded, ${ }^{88}$ or sintered in a Solgel process. ${ }^{24}$ The glass optics are glued, for example, with a silicone glue onto the solar cell. The silicone optics are directly casted by overmolding ${ }^{89,98}$ or also glued to the solar cell. However, choosing the right silicone is important. In Ref. 98, it was shown by Victoria et al. that Polyphenyl-methylsiloxane (PPMS) was destroyed when operated outdoors, whereas Polydimethylsiloxane (PDMS) did not show degradation.

\section{B. Solar cell}

\section{Solar cell architectures}

Designing a multi-junction solar cell allows the choice from a variety of materials with different bandgaps and different processes. In Fig. 10, different materials and technologies are listed that are available to design a III-V based multi-junction solar cell. III-V compound semiconductors are grown on a doped substrate like germanium $(\mathrm{Ge})$, silicon (Si), gallium arsenide $(\mathrm{GaAs})$, gallium antimonide $(\mathrm{GaSb})$, or indium phosphide (InP). The photovoltaic active material needs high crystal perfection in order to avoid recombination of generated minority carriers at defects. The complete solar cell structure is usually grown by metal organic vapor phase epitaxy (MOVPE). Because of the suitability for higher throughput production, it is preferred to other growth methods like molecular beam epitaxy (MBE), although for certain III-V layers like GaInNAs MBE delivers the better material quality. ${ }^{99,100}$ A multi-junction solar cell consists of 20 to 50 individual layers grown following different approaches. The first approach investigated was to grow lattice matched materials with increasing bandgap on top of each other. This is named as the upright growth method. It turned out, when growing on an activated Ge substrate, the current matching

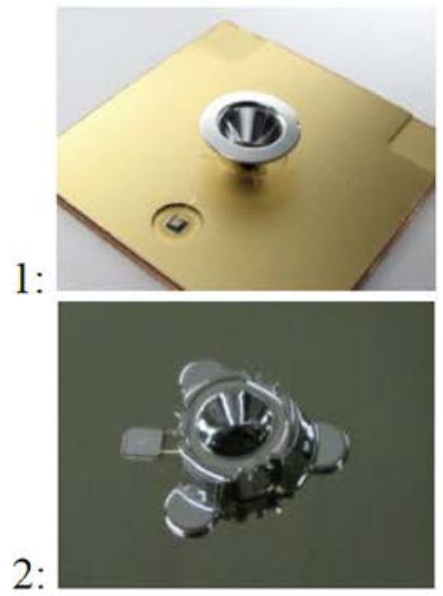

(a)

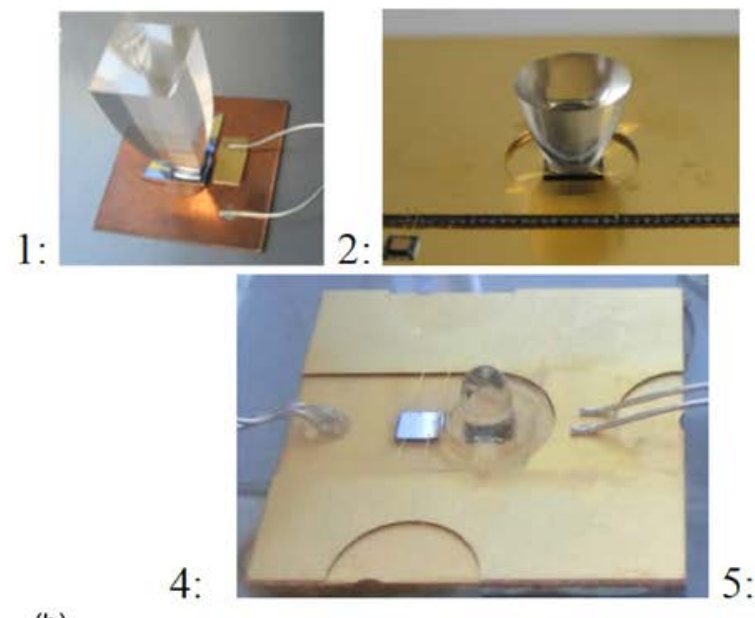

3:

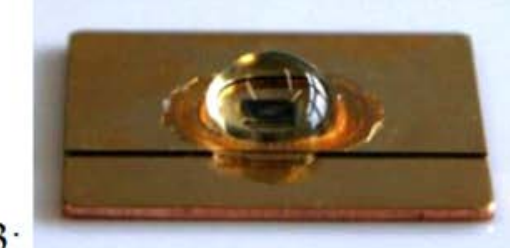

$5:$

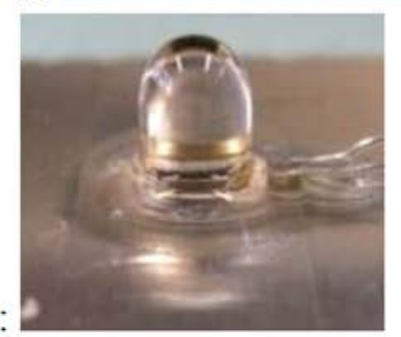

FIG. 9. Examples of solar cell assemblies with secondary optical elements developed and investigated at Fraunhofer ISE. (a) (1): Conical as developed in Jaus et al. ${ }^{95}$ (2): Reflective secondary optics with legs for mounting. (b) Refractive optics with (1): CPC further detailed in Ref. 96, (2): refractive optics made of PMMA, (3): spherical silicone based secondary developed within the NACIR project, ${ }^{97}$ (4): directly casted dome shaped silicone, ${ }^{89}$ and (5): glass molded secondary further investigated in Ref. 89. 


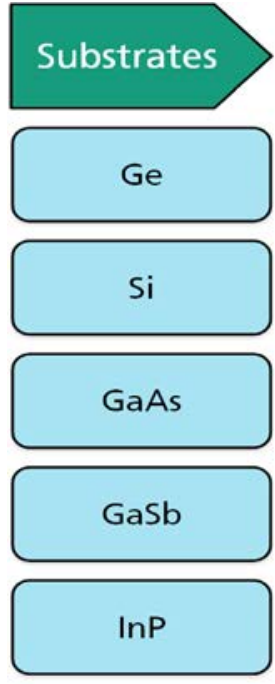

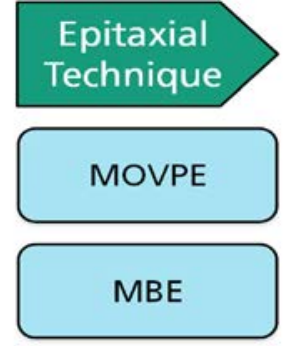

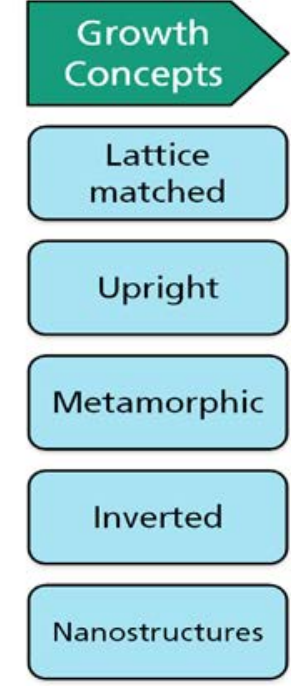

Post-growth

Processing

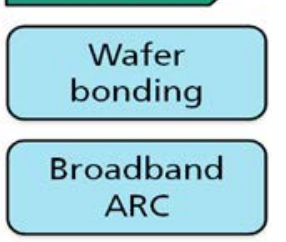

Metallisation

Grid design
FIG. 10. Materials, technologies, and processes used to design new highefficiency III-V multi-junction solar cells (adapted from Ref. 108). condition cannot be achieved. ${ }^{101,102}$ Therefore, the metamorphic (MM) growth concept was developed. ${ }^{103-105}$ This concept introduces buffer layers in between the photovoltaic active solar cell where the lattice constant of the grown material changes. ${ }^{106}$ In consequence, defects are generated in the crystal. The concept aims to localize all defects in the buffer layer; no defects should penetrate into photovoltaic active layers. Appling this approach, it was possible to select the best bandgaps for each subcell in order to achieve a current matched triple-junction solar cell on active Ge. ${ }^{107}$ However, for certain architectures, growing high bandgap materials before materials with lower bandgaps leads to better solar cell performance. Note, after the growth, the substrate has to be removed and the grown structure is turned around. This approach is named as the inverted growth concept. Recently, the activated wafer bonding process has been introduced for multi-junction solar cells. This bonding process combines two semiconductors on atomic scale, thus leading to a monolithic block. This allows the combination of high quality materials with different lattice constants without introducing crystal defects. The wafers with the epitaxial layers are finally processed into solar cells (i.e., anti-reflection coating (ARC) and metallization for contacts are added). The huge variety of materials and technologies gives a lot of room for optimization of the individual cell architecture.

A more detailed description about multi-junction solar cells can be found in Ref. 109. Some important solar cell structures and current statuses are described in the following paragraphs.

a. Upright growth concept. In the upright growth concept, different III-V composites are grown subsequently on a substrate starting with the material providing the lowest bandgap. In the photovoltaic active materials with different bandgaps, the introduced pn-junction causes the separation of the generated carriers. Barrier layers (back surface and front surface field) are introduced to passivate the boundaries of the respective pn-junction. Each of the subcells is internally connected via a tunnel diode. Thus, the subcells are connected in series which sums up the voltage of each subcell but limits the output current to the minimum of the subcells' currents. For highest efficiency, the current matching condition must be achieved, i.e., each subcell generates the same current under illumination with the solar spectrum.

State of the art multi-junction solar cells are triplejunction solar cells as shown in Fig. 11 with the lattice

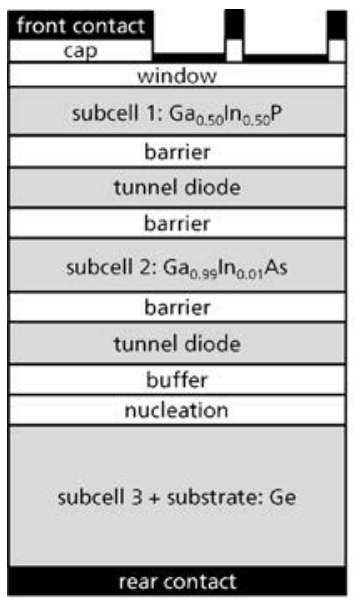

(a)

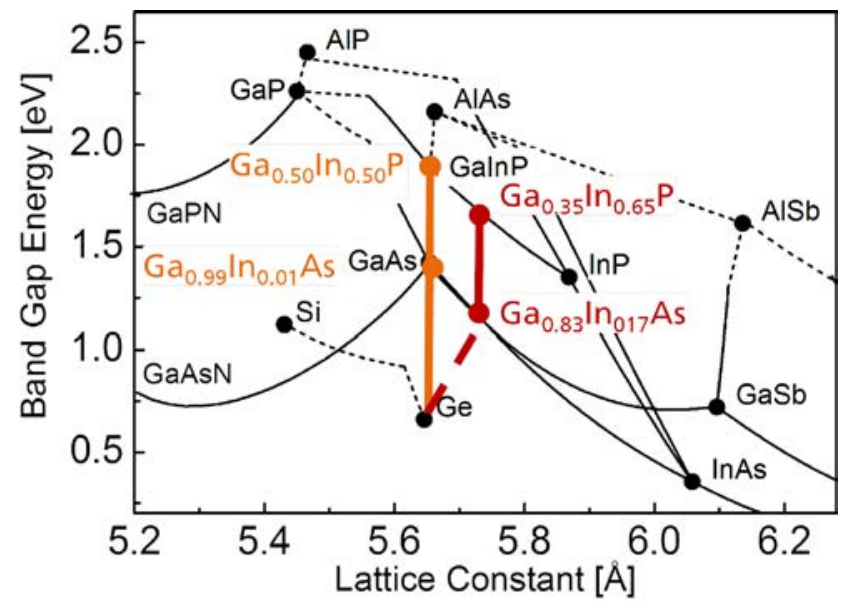

(b)
FIG. 11. (a) Major layers in a twoterminal lattice matched triple-junction solar cell. The materials in the lattice matched triple-junction subcell (1): $\mathrm{Ga}_{0.50} \mathrm{In}_{0.50} \mathrm{P}$, subcell (2): $\mathrm{Ga}_{0.99} \mathrm{In}_{0.01} \mathrm{As}$, and subcell (3): Ge. (b) Bandgap energy versus lattice constant for different III-V materials. Germanium, indium phosphide, and silicon are also shown. The lattice matched and the metamorphic (MM) cell structures are shown in orange and red. The MM cell has a band gap energy of $1.67 \mathrm{eV}$ for $\mathrm{Ga}_{0.35} \mathrm{In}_{0.65} \mathrm{P}$, $1.18 \mathrm{eV}$ for the subcell $\mathrm{Ga} 0.83 \operatorname{In}_{0.17} \mathrm{As}$, and $0.66 \mathrm{eV}$ for the $3 \mathrm{rd}$ subcell Ge. 
matched structure (LM) $\mathrm{Ga}_{0.50} \mathrm{In}_{0.50} \mathrm{P} / \mathrm{Ga}_{0.99} \mathrm{In}_{0.01} \mathrm{As} / \mathrm{Ge} .{ }^{109}$ The highest reported efficiency of a lattice matched triplejunction solar cell is $40.1 \%$ (at 135 suns). ${ }^{110}$

However, in the lattice matched structure, the Ge subcell generates more current than the two upper cells. In order to achieve a current matching condition, the bandgap of the two upper subcells should be lowered. This is possible by changing the material composition of the ternary compounds but at the expense of losing the lattice matching conditions, see Fig. 11(b). The metamorphic growth concept was successfully introduced: in 2009, a metamorphic but current matched triple-junction solar cell with $\mathrm{Ga}_{0.35} \mathrm{In}_{0.65} \mathrm{P} / \mathrm{Ga}_{0.83} \mathrm{In}_{0.17} \mathrm{As} / \mathrm{Ge}$ and record efficiency of $41.1 \%$ (at 454 suns) was realized. ${ }^{107}$

$b$. Inverted growth concept. The inverted growth concept was introduced since high bandgap material can be grown with highest quality lattice matched on a Ge or GaAs substrate. ${ }^{102,111}$ Afterwards, the metamorphic growth approach is used to provide the suitable low bandgap materials. In this way, the bottom pn-junction germanium can be replaced with a different bandgap material. The highest efficiency for a triple-junction solar cell with an inverted metamorphic structure (IMM) was achieved by Sharp with a InGaP/GaAs/ InGaAs solar cell measured with an efficiency of $44.4 \%$ at 302 suns. ${ }^{112}$ The efficiency can be increased further by introducing additional pn-junctions. The IMM four junction solar cell GaInP/GaAs/GaInAs/GaInAs from the National Renewable Energy Laboratory (NREL) ${ }^{113}$ achieved an efficiency of $45.7 \%$ (at 234 suns). ${ }^{114}$

c. Wafer bonding. The metamorphic growth approach still introduces some defects into the photovoltaic active materials. The risk of dislocations can be omitted when two wafers are tied by direct wafer bonding. ${ }^{108}$ This technology concept also increases the choices of differences in the lattice constant and substrate materials. Two solar cell architectures (could be single-, dual-, or triple-junctions) are grown on separate substrates. One structure is grown inverted. The wafers with the grown structures are bonded together and afterwards at least one substrate is removed. For transparent and electrically conductive bonds with high bond strength, molecular bonds are necessary. Plasma activation of the bonding surfaces improves the bonding strength. ${ }^{115}$ The requirement of surface quality for this process is rather high with roughness below $1 \mathrm{~nm}$ RMS. ${ }^{116,117}$ Moreover, a low density of particles must be achieved by an additional polishing processing step [e.g., chemical mechanical polishing (CMP)]. A wafer bonded four-junction solar cell structure has shown the highest efficiency of all solar cells with $46.0 \%{ }^{4,114}$ The potential for the solar cell in a CPV system was investigated with a four-junction solar cell characterized when illuminated with concentrated solar radiation from a full-glass achromatic lens. The mini-module had an efficiency of $43.4 \%$ at CSTC. ${ }^{118}$

For the wafer bonded or IMM structures, substrates need to be removed in a lift-off process. With epitaxial lift off (ELO), the wafer is separated by etching and scarifying a release layer. ${ }^{119-122}$ The lifted structures are within a few micrometers in thickness. Handling of the lifted structures and even further processing to apply anti-reflection coating (ARC) and electrical contact are required. Bauhuis et al. showed in Ref. 123 that the same efficiencies are possible for cells with a lifted solar cell compared to a solar cell on substrate. They investigated a GaAs single junction solar cell that achieved efficiencies of $26.1 \%$ (under AM1.5g conditions) for both cell types. The highest efficiency was achieved by Alta Devices ${ }^{124}$ with $28.8 \%$ efficiency (under AM1.5g). ${ }^{114}$ For cost reduction and conservation of resources, a re-use of the substrate would be beneficial. Adams et al. showed in Ref. 125 that with reuse of a GaAs substrate, after five growth cycles, the solar cell efficiencies were in the same range.

d. Four terminal solar cells. So far, devices with two electrical terminals were discussed with the challenge of current matching of the pn-junctions. However, before tunnel diodes were available, solar cells were mechanical stacked. ${ }^{126}$ In 2002, a triple-junction solar cell made of $\mathrm{GaInP} / \mathrm{GaInAs}$ and $\mathrm{GaSb}$ of $33.5 \%$ at $308 \times$ was presented. ${ }^{127}$ Today, the highest triple-junction solar cell efficiency for a GaInP/GaAs mechanically stacked to $\mathrm{Si}$ subcell reached $35.9 \%$ under AM1.5g spectral conditions. ${ }^{128}$ Stacking two solar cell devices requires four terminals that are interconnected and usually also require two independent circuits in the CPV module; this means increased effort for interconnection. This is possible when introducing new processing technologies on wafer level like transfer printing as proposed in Refs. 129-131.

e. Current development to increase the efficiency and reduce costs. Increasing the efficiency and reducing the costs for the solar cells are the main target of current research. In terms of costs, the advantage of the upright growth is that only one growth process and no additional processing steps are required. Higher efficiencies with lattice matched materials can be achieved by introducing more pn-junctions. GaInNAs would be an interesting material for a four-junction solar cell. It provides the requested $1 \mathrm{eV}$ bandgap. ${ }^{100} \mathrm{~A}$ triplejunction device of GaInP/GaAs/GaInNAs grown with MBE has been developed reaching an efficiency of $43.5 \%$ (at $925 \times) .{ }^{132}$ Even more junctions-five to six-have been developed. ${ }^{133-135}$ For those devices, the perspective of yearly energy harvesting in a CPV system has been investigated and it was shown that more junctions are beneficial. For example, using a five-junction solar cell instead of a four-junction solar cell $^{136}$ gives 3\% increase in energy harvesting at three investigated CPV locations (Boulder, USA, El Arenosillo, Spain, and Sede Boker, Israel).

Using silicon as a substrate offers potential for substantial cost reduction but also higher efficiencies for a lattice matched structure by replacing the bottom junction of germanium with a higher bandgap material of $1.12 \mathrm{eV} .{ }^{115}$ As the germanium subcell generates excess current in a lattice matched triple-junction solar cell under the solar spectrum, the total efficiency increases with a current matched structure. So far, for a wafer bonded two terminal GaInP/GaAs//Si solar cell, an efficiency of $30.0 \%$ at $112 \times$ was achieved. ${ }^{137}$ The highest efficiency is $33.3 \%$ for $\mathrm{GaInP} / \mathrm{GaAs} / / \mathrm{Si}$ solar cell- 
however, not under concentrated illumination but the global AM1.5g spectrum. ${ }^{114}$

\section{Electrical design in the module: Interconnection of solar cells}

a. Series and parallel interconnection. In the module, the solar cells are interconnected electrically in series or in parallel. The power generated in each solar cell in the module can vary due to different cell or optical performance. Voltage differences mainly result from different operating temperatures. Differences in current are caused by differences in optical efficiency that result in different flux intensities. The solar cells also perform differently through inhomogeneous material quality resulting in series or shunt resistances or processing failures causing differences in size of active area or non-uniform anti-reflection layer. Finally, errors in the assembly process or through shadowing during operation can result in differences in performance (see also Subsection II B 2 b). In contrast to silicon PV modules, because of high current densities in CPV cells, each element of a string is protected with a bypass diode that is connected anti-parallel. The size of the bypass diode is defined by the current of the string. In addition, the electrical power needs to be dissipated in the bypass diode when it is in forward operation. The power is distributed by the substrate and therefore good thermal contact is required. Because of their good technical and economical properties, silicon Schottky diodes packaged or unpackaged are commonly used.

As the voltage differences are less severe, parallel interconnection is theoretically beneficial. That was shown in Ref. 138 where serial and parallel interconnection schemes were investigated for differently performing solar cells (e.g., due to difference in current generation or temperature). However, this also means high currents causing higher ohmic losses. In addition, Steiner et al. investigated in Refs. 139 and 140 the risk for thermal runaway in a parallel interconnection. The thermal runaway effect describes a selfstrengthening heating till the solar cell is destroyed. ${ }^{140,141}$ They recommend a combination of parallel interconnection of few cells (currents low enough to avoid thermal runaway) that are then connected in series. To prevent a temperature increase in $20 \mathrm{~K}$ at $500 \times$ concentration, the number of solar cells in parallel should be limited to five-assuming a cell current density of $15 \mathrm{~mA} / \mathrm{cm}^{2}$ at one sun $\left(0.1 \mathrm{~W} / \mathrm{cm}^{2}\right)$ and $5 \mathrm{~mm}^{2}$ cells. Then, the current density $\mathrm{J}_{\mathrm{SC}}$ of one cell is $7.5 \mathrm{~A} / \mathrm{cm}^{2}$ (corresponding $0.375 \mathrm{~A}$ ). Regarding the module manufacturing process, it has to be considered that the parallel interconnection requires more interconnects since both the terminals are always interconnected. ${ }^{140,141}$ Solar cells or a solar cell string in parallel connection can be protected from reverse current by a blocking diode connected in series. ${ }^{142}$ However, blocking diodes that are forward biased reduce the voltage of the string. Therefore, usually only complete modules or trackers are protected with blocking diodes.

b. Influence of misalignment of optical element to solar cell on module performance in a series interconnection. The narrow acceptance angle of CPV optical systems, typically between $0.5^{\circ}$ and $1^{\circ}$, leads to very tight mechanical tolerances in the manufacturing and assembly of CPV sub-parts and modules. Mechanical errors, delimited by tolerances, produce optical misalignments among the units composing the modules (single lens_cell unit) and arrays (modules) and degrade the angular performance of the module. This can lead also to significant electrical degradation. In silicon flat plate panels, the dispersion in the electrical performance of the cell is the main cause of mismatch losses. In CPV, optical mismatch, specially caused by misalignments of the optical element, can become the main source of mismatch losses. Losses caused by the dispersion of optical parameters and misalignments in CPV where early reported in Ref. 143. In Figs. 12(a) and 12(b), an example for the relative angular

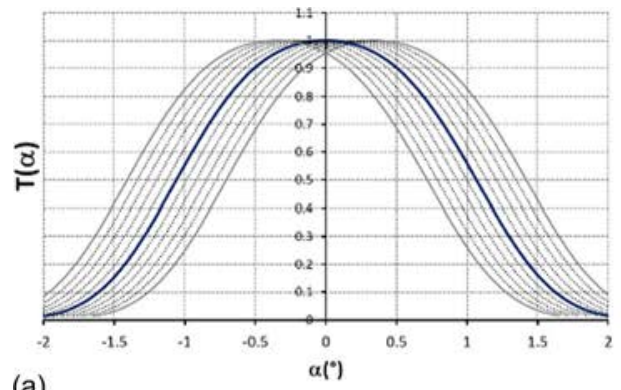

(a)

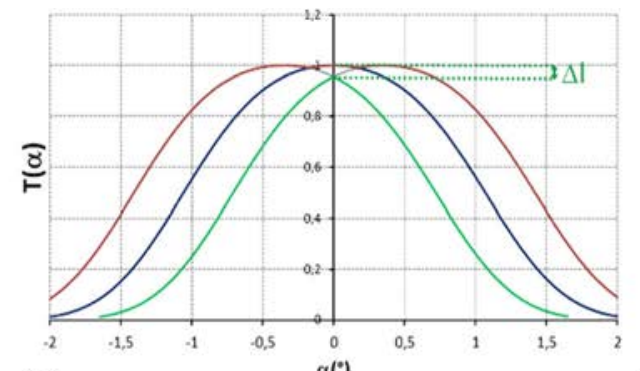

(b)

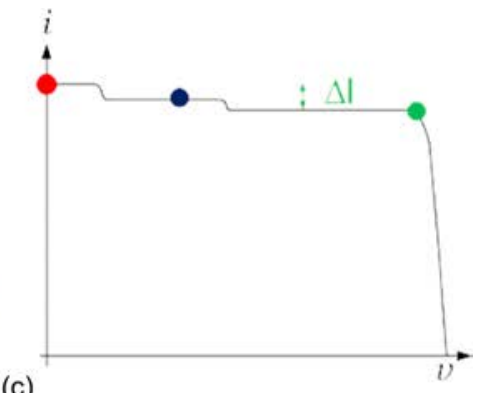

(c)

FIG. 12. Case study for exemplifying the impact of misalignments in the optical and electrical performance of a CPV module. The example CPV module consists of three lens-cell units, with acceptance angle $\alpha_{90 \%}=0.5^{\circ}$ and optical misalignments of two units of $-0.35^{\circ}$ and $+0.35^{\circ}$ (grey continuous lines in left plot) in respect to the reference unit (blue line in left and central plots). In a real case of many more units, this two can be considered as the most misaligned units, being the others within $\pm 0.35^{\circ}$ (dotted lines in the left plot). It has been assumed that the maximum transmission values for all units are the same, i.e., all lens-cell units produce exactly the same current at perfect alignment. The left plot (a) shows the relative angular transmission functions of each lens-cell unit in respect to the optical axis of the reference unit (in blue). The middle plot (b) shows the resulting transmission function of the three units connected in series (each unit includes a bypass diode), for different bias voltage of the string. At short circuit $\left(I_{S C}\right)$, the transmission curve is given by the highest value at each angular position (red line), i.e., the upper envelope of individual curves. The result is a significantly wider transmission curve at $\mathrm{I}_{\mathrm{SC}}$. But at the maximum power point $\left(P_{M P P}\right)$, the transmission curve is limited by the worst value at each angular position (green line), i.e., the lower envelope of individual curves. The result is a current loss $(\Delta I=5 \%)$ at perfect alignment of the module, but which is even worse, a reduction in the angular transmission in power of the module $\left(\alpha_{90 \%}=0.15^{\circ}\right)$. The right plot (c) shows the resulting IV curve of the three units connected in series, where each color dot shows the bias voltage corresponding to the transmission curves of plot (b). The IV curve of a real module with more units connected in series would show a slope from $\mathrm{I}_{\mathrm{SC}}$ to $\mathrm{P}_{\mathrm{MPP}}$ similar to that caused by a low parallel resistance. 
transmission curves $T(\alpha)$ for two misaligned cell-lens units is shown. The acceptance angle of the cell-lens-unit is $\alpha_{90 \%}=0.5^{\circ}$, and the solar cells are series interconnected and each connected with a bypass diode. Two lenses are misaligned between $-0.35^{\circ}$ and $0.35^{\circ}$. For one lens misaligned by $0.35^{\circ}$ and the other by $-0.35^{\circ}$ [Fig. 12(b)], the current is reduced for perfect alignment $(\Delta \mathrm{I}=5 \%)$ and at the same time the angular transmission in the power of the module is reduced $\left(\alpha_{90 \%}=0.15^{\circ}\right)$. In Fig. 12(c), the points of bias voltage from the curves in diagram (b) are shown by the colored dots. It becomes obvious that the acceptance angle measured at short circuit $I_{S C}$ for misaligned optics is higher than measured at maximum power point $P_{M P P}$.

The CAP value of an optical design defines the acceptance angle for a concentration level. The higher the acceptance angle, the higher the angular tolerance, which can be invested in higher mechanical tolerances in a manufacturing line for CPV modules or lower stiffness requirements in the tracker structure. So, acceptance angle should not be wasted, but used to reduce cost of the module or tracker. Several studies have been carried out to determine the impact of misalignment distributions in the module performance. Araki et al. studied in Ref. 144 the impact of assembly errors, compared to the acceptance angle of the elementary unit. Herrero et al. proposed an inverse method ${ }^{145}$ to determine the $2 \mathrm{D}$ angular transmission function of CPV optics and modules by evaluating the light emission of a forward biased module. The method makes it possible to determine the individual transmission function of each lens-cell unit, as well as the angular misalignment among them ${ }^{146}$ and its evolution with temperature. ${ }^{147}$ It has been also used to characterize a production line, quantify defects causing misalignments and determine its impact in the system performance. ${ }^{148}$

\section{Optical design and current distribution in the solar cell in the CPV module}

a. Approach for design by simulation. The solar cell and the optics need to match well in the module. The first design parameter is the dimensions of the components that determine the power per cell and therefore the total current. The flux distribution on the solar cell given by the optical element(s) is spectrum and wavelength dependent.

For the optical design, radiation within the opening half angle of $0.267^{\circ}$ comes from the sun disc with decreasing intensity to the disc edges (limb darkening). The aureole or circumsolar radiation (CSR) that results from radiation absorbed and scattered in the atmosphere contributes to the electricity generation. The influences are wavelength dependent and dependent on the atmospheric conditions. In the 1970s and 1980s, measurements of the sun shape were carried out by the Lawrence Berkeley Laboratory. ${ }^{149}$ Later in Ref. 150, Neumann et al. published intensity profiles for different CSR values measured at three different sites. They are a good basis for modeling CPV systems. The optical design is evaluated by the optical geometry including material properties (absorption, refraction, and reflection), dimension, shape, and optical losses due to shape tolerances and/or scattering. For the optical design, additional factors-for example, for tracking accuracy—need to be considered. In theoretical simulation in Ref. 76, consideration of the losses due to tolerances with normally distributed standard deviation is proposed.

On the solar cell device level, the front contact grid metallization is adapted for the flux intensity. This includes adaptation to a non-uniform profile given by the optics but also to optimize the shading losses versus resistive losses. ${ }^{151}$ This means that the optimized grid strongly depends on the current densities, i.e., concentration factor resulting in radially symmetrical rather than parallel finger spacing. ${ }^{152}$ To quantify the non-uniformity of the flux distribution on the solar cell, the peak-to-average (PAR) value is introduced. ${ }^{153}$ The PAR is given by the maximum and minimum concentration on a solar cell area. Theoretical simulations are carried out to optimize the system iteratively, for example, with network simulation to determine the electrical output. ${ }^{154}$ In the network simulation, the pn-junctions of solar cells are simulated with the two diode module including additional layers (conduction layers and tunnel diode). The current densities result from the flux profile on the solar cell. Sheet resistances and dimensions need to be available for all layers including the grid metallization (values for a triple-junction solar cell are given in Ref. 155). Perimeter recombination and dark current losses in shaded areas are considered as well. The layout of the grid-like finger distances or finger arrangement is then optimized to match the optics. ${ }^{152,156}$

b. Matching the focal distance to the lens optics and solar cell: Optimum cell-lens distance. In a CPV module, the optical element, solar cell, and spectral conditions determine the performance of the module. Practical definitions for CPV optical efficiencies that include the cell performance are discussed in Refs. 157 and 158.

The optimum distance between solar cell and lens is one parameter which is strongly influenced by the interaction between the optics and solar cell. Especially for lenses with chromatic aberration, the distance influences the amount of photons available for absorption and the lateral distribution of photons in the subcells. ${ }^{83,159}$ Figure 13 shows the impact of the cell-lens-distance on the current-voltage characteristics of a multi-junction solar cell. The graph (a) in Fig. 13 shows the current density and fill factor $(F F)$ as a function of cell to lens distance. The drop in current density is caused by photons missing the current limiting subcell's active area. Due to the series connection of the subcell in the multijunction solar cell, the current density of the solar cell is defined by the current generation in the current limiting subcell. Because of chromatic aberration, it is most likely that for different cell-lens-distances, different subcells limit the current. The wavelength-dependent focal length results in differences in the lateral current generation profiles of the subcells. Significant lateral current redistribution along the semiconductor sheet layers is required causing losses together with the sheet resistances of the layers due to series resistance. Series resistance losses strongly affect the FF of the solar cell I-V curve. In the example shown in Fig. 13(a), at a relative cell-lens-distance of -1 , the current generation profiles in the subcells are similar and thus the lateral current 

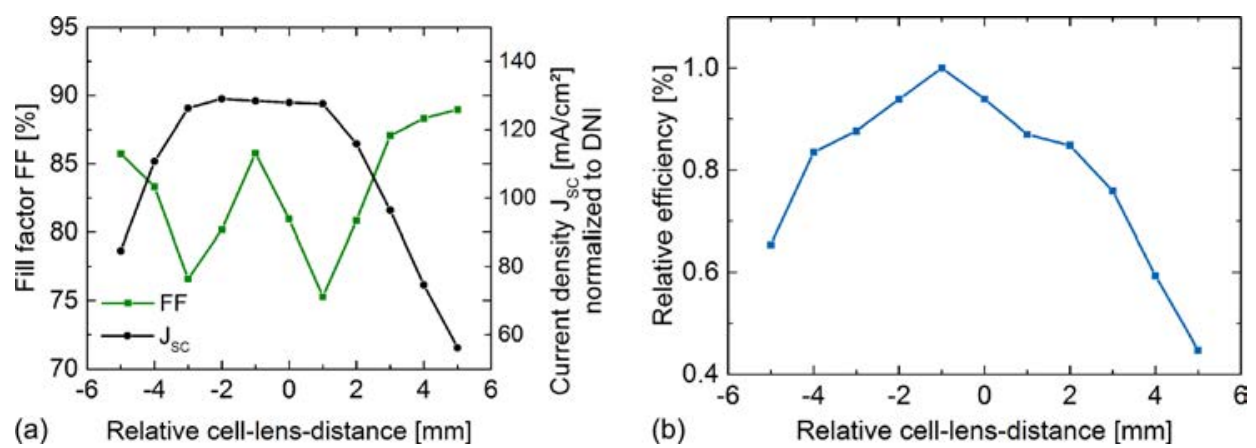

FIG. 13. Example cell-lens distance measurement. The distance between a SoG Fresnel lens and a triple-junction solar cell is varied. For each cell-lens-distance, the current-voltage characteristics of the solar cell are measured at the outdoor test-set-up in Freiburg. During the measurement, temperature and spectral conditions were stable. The diagram (a) shows the fill factor and the current density normalized to direct normal irradiance (DNI) as a function of cell-lens-distance. Steiner et al. in Ref. 159 showed that the strong variation of FF with cell-lens-distance is due to different flux profiles on/in the subcells because of chromatic aberration. This requires lateral current redistribution in the solar cell causing series resistance losses. (b) Diagram of the efficiency for different cell-lens distances.

flow is at minimum. For slightly higher or lower cell-lensdistances, the lateral current flow and thus the series resistance losses are increased which cause a drop in FF. For celllens-distances higher than +1 and lower than -3 , the fill factor increases because photons are missing the solar cell active area. This reduces the current of the subcells differently and strong current mismatch of the subcells results in higher FF. ${ }^{160}$

The combination of FF and current density dependency as described above causes the dependency of module (or solar cell) efficiency on lens-cell-distance as shown in Fig. 13(b) with a peak in the efficiency. However, the efficiency dependency on cell-lens-distance varies for different ambient conditions; the spectral distribution and the ambient temperature have a particularly strong impact on the cell-lens-distance. ${ }^{157}$ This needs to be taken into account when setting the module height.

\section{Heat distributor}

The high number of variables for designing CPV modules results in different solutions and setups. An approach to classify the different solutions is based on how the heat is distributed. Assuming solar radiation with $1000 \mathrm{~W} / \mathrm{m}^{2}$, $1000 \times$ concentration, $85 \%$ optical efficiency and that the system operates in open-circuit conditions, the maximum heat flux reaches $85 \mathrm{~W} / \mathrm{cm}^{2}$. Under operation condition, the flux is additionally reduced by the electrical energy that is extracted. In passively cooled systems, the thermal energy is transferred to the environment in a two-step process: first, by thermal conduction to a larger area (the heat distributor) and then by transferring with convection and radiation to the environment. In actively cooled systems, the heat exchange is enforced by an external cooling cycle. A heat transfer fluid is used which can be either forced air circulation or a liquid like water. In this way, the thermal energy is transferred efficiently to a consumer, storage, or chiller. In Fig. 14, the heat transfer between the ambient and module (a) or dense array receiver (b) is shown.

For the thermal design, the most critical interface is identified between the solar cell and the substrate. The solar cells are soldered or glued to the substrate and high thermal and electrical conductivity are required. The thermal conductivity of solder alloys (50 to $60 \mathrm{~W} /(\mathrm{m} \mathrm{K})$ ) is higher than for electrically conductive adhesives with (1 to $2 \mathrm{~W} /(\mathrm{m}$ $\mathrm{K})^{161}$ ). In addition to the lower thermal conductivity for adhesives, there is an additional contact resistance at the interfaces to the cell and substrate. During cell attach process, void formation may occur. ${ }^{162}$ Voids are critical as they increase the thermal resistance and thermal mechanical stress. Bosco et al. describe in Ref. 141 that large voids may be the origin of the thermal runaway effect. Bosco et al. recommended a void content $<4 \%$ to avoid this thermal runaway. Foresi et al. specified in Ref. 163 a total void content over the area of lower than $5 \%$ for a $1 \mathrm{~cm}^{2}$ cell with no void larger than $2.5 \%$. Wiesenfarth et al. showed in Ref. 164 that for a $1 \mathrm{~cm}^{2}$ solar cell, even a void content $<1 \%$ is possible when vacuum soldering processing is applied. Besides the thermal conductivity, long term stability is also important for the interconnection layer between solar cell and substrate in the receiver. In solder layers, cracks can

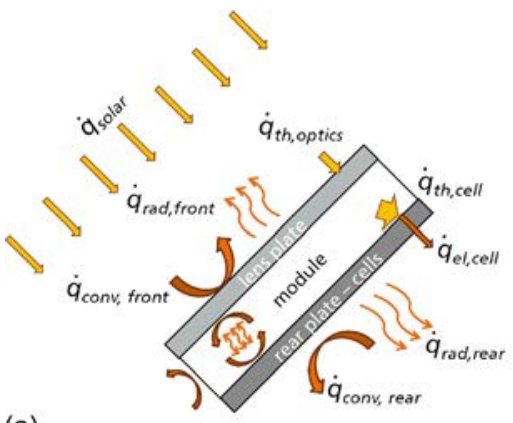

(a)

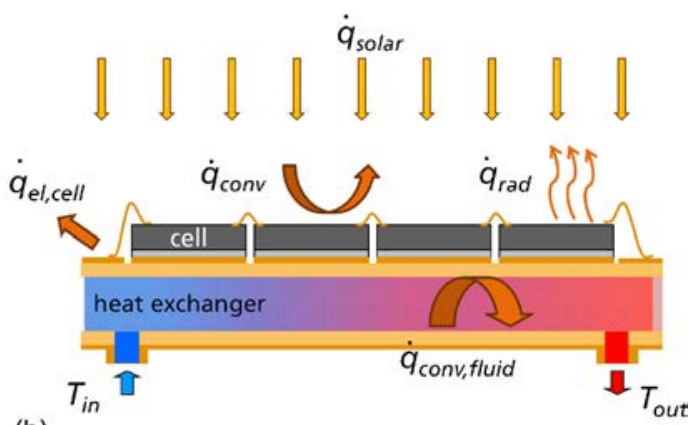

(b)
FIG. 14. Main heat transfer mechanisms in a CPV module with thermal flux $\dot{q}_{\text {solar }}$, absorbed thermal power $\dot{q}_{t h, c e l l}$, electrical power generated in the cell $\dot{q}_{e l, c e l l}$, absorbed thermal power in optics $\dot{q}_{\text {th,optics }}$, and thermal transfer by convection (conv) and radiation (rad). Lens based module with passive (a) and receiver with heat exchanger for active heat distribution with a liquid cooler (b). Conduction in the material is not shown. 
develop due to changes of the chemical composition in the solder joints combined with thermo-mechanical stress and humidity. This can be critical for the reliability. It was shown that the crack formation is not as relevant for electrical and thermally conductive adhesives. However, the thermal resistance is higher for adhesives resulting in higher solar cell temperatures. During the mounting process for large area solar cells $\left(>1 \mathrm{~cm}^{2}\right)$, low void content is also more difficult to obtain. A more detailed discussion on the trade-offs between solders and adhesives can be found in Ref. 165 by Wiesenfarth et al.

\section{Passive heat distribution}

Reasonable passive heat distribution is possible for small solar cells mounted to a heat distributer made from a material with good thermal conductivity (i.e., metal: aluminum, copper). Here, lenses or mirrors with aperture areas up to $400 \mathrm{~cm}^{2}$ are used as concentrating optics in a module. Larger optics are possible with cooling fins or heat pipes and are essential for large aperture areas of the elementary optical unit. Askins and Pano ${ }^{166}$ determined the impact of the aperture size in the thermal design: up to $100 \mathrm{~cm}^{2}$, a simple aluminum plate can properly perform as a heat distributor, but from $400 \mathrm{~cm}^{2}$ upwards (up to $1 \mathrm{~m}^{2}$ ) a finned heat distributor is clearly necessary. Between $100 \mathrm{~cm}^{2}$ and $400 \mathrm{~cm}^{2}$, finned heat distributors can potentially be avoided with proper thermal design. Implementing cooling fins increases the complexity of the module design but with the enhanced heat transfer, larger solar cells can be used which leads to fewer parts per Watt in the module that needs to be handled during the assembly process. In addition, tolerances in positioning during assembly are higher by assuming that it is possible to achieve the same absolute displacement of a few tens of micrometers for the placement accuracy. Fins are foreseen in the modules from Emcore, ${ }^{167}$ Suncore, ${ }^{61}$ and Heliotrop. ${ }^{166}$

In Fig. 15(a), an example of solar cells mounted to a metal plate for passive heat distribution and rear glass plate as in the FLATCON ${ }^{\circledR}$ module is shown. In Fig. 15(b), the equivalent circuit diagram for a lens-based module is shown. The heat input $\dot{q}_{\text {th,cell }}$ depends on the dimensions (aperture area of the primary optics) and operation open-circuit conditions for extracting electrical energy $\dot{q}_{\text {el,cell }}$. The thermal resistance between the solar cell and the substrate $\left(R_{\text {cond,die-attach }}\right)$ strongly depends on the materials used. For thermal transfer, thermal resistance for free convection at the module-air interface $\left(R_{\text {conv }}\right)$ with 0.2 to $0.1\left(\mathrm{~m}^{2} \mathrm{~K}\right) / \mathrm{W}$ can be assumed. Convection also takes place transferring heat between the inside of the module and the ambient environment. Radiation $\left(R_{\text {rad }}\right)$ should not be neglected-especially, on the rear side of the module where large temperature differences occur. Glass as a rear plate has a high emissivity between 0.92 and 0.95 . For metal rear plates with lower emissivity, Nishioka et al. proposed in Ref. 168 that in the investigated design, temperatures were $10 \mathrm{~K}$ lower when applying a coating to the metal rear side to increase emissivity.

\section{Active heat distribution with dense arrays}

Aperture areas of the optical elementary unit larger than $1 \mathrm{~m}^{2}$ lead to actively cooled systems. Typical examples are point focusing mirrors based on parabolic dishes, heliostat fields, or linear troughs (in HCPV with secondary optics and two axis tracking). Such primary concentrating optics yield a large focal spot of $5 \mathrm{~cm}^{2}$ up to $1 \mathrm{~m}^{2}$ and require a correspondingly dense array of solar cell receivers. In the dense array receiver, the solar cells are mounted to a heat exchanger using a cooling fluid for heat transfer. Square meters of dense arrays are used in CPV tower systems. ${ }^{58}$ For example in Refs. 52 and 169-173, several actively cooled systems are presented. The company Solar System (later Silex) has developed large mirror dish CPV systems since the $1990 \mathrm{~s}^{174}$ and had installed more than $4 \mathrm{MW}$ as of 2014 . $^{11}$ The dense array receiver technology is also used in a CPV tower system with the advantage that the electricity generation is centralized at one point of the tower. $^{58}$ Today, a $200 \mathrm{~kW}$ commercial tower technology is provided by Raygen. ${ }^{53}$

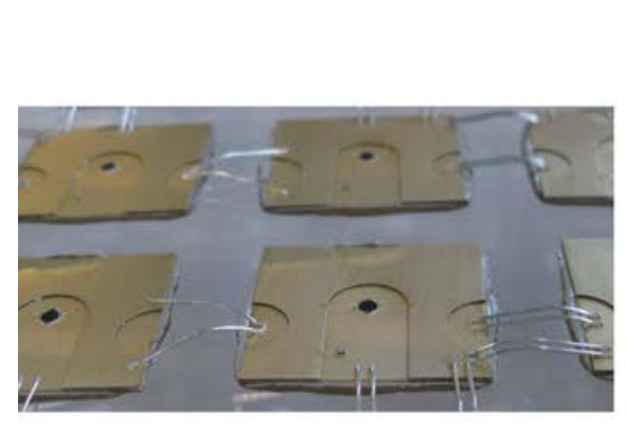

(a)

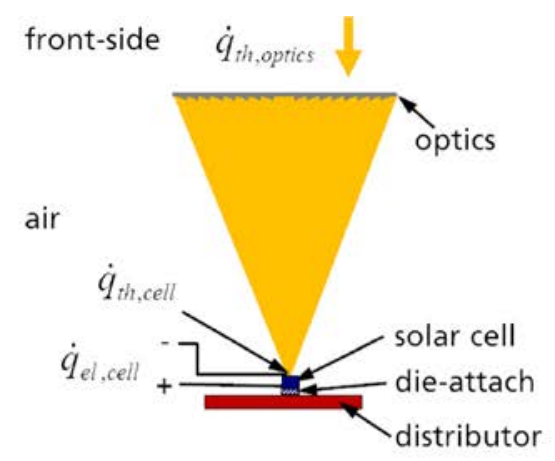

rear-side

(b)

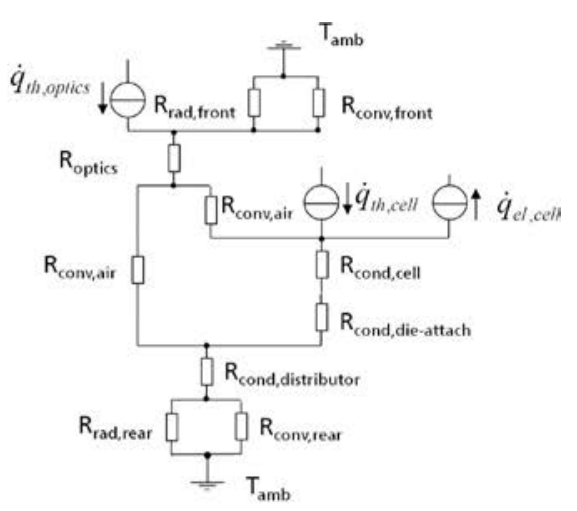

(c)

FIG. 15. (a) Example of passive heat distribution: solar cell assemblies (solar cell, bypass diode, heat distributor, and electrical contacts) mounted on a glass plate in a FLATCON ${ }^{\circledR}$ module. Electrical interconnection between the assemblies by heavy wire bonding can also be seen. (b) Sketch of the assembly and (c) equivalent circuit diagram for the lens-based module including thermal fluxes, thermal resistances (R) for the different components, and thermal transition to ambient (convection inside of the module and at the frame is neglected) by convection (conv) and radiation (rad) [compare also Fig. 14(a)]. The absorbed thermal power $\dot{q}_{t h, c e l l}$, electrical power generated in the cell $\dot{q}_{\text {el,cell }}$, and absorbed thermal power in the optics $\dot{q}_{t h, o p t i c s}$ as well as ambient temperature $\mathrm{T}_{\mathrm{amb}}$ are included. 
Most actively cooled systems take advantage of the system configuration and offer co-generation of thermal energy $(\mathrm{CPV}-\mathrm{T})$. Using the thermal energy, Helmers et al. ${ }^{175}$ showed that the total conversion efficiency (generated electrical and thermal energy) can be up to $75 \%$. One reason for the high efficiency is that high concentration is also an advantage for the thermal energy transfer. In thermal absorbers with small area, losses due to convection and radiation are lower compared to the non-concentrated absorber area. The challenge for the CPV receiver in the described application is that the solar cells need to be mounted with high packing factor (dense array) with low thermal resistance to the heat exchanger. Typically, cells are electrically interconnected in series and bypass diodes implemented. The standard interconnection method for a solar cell is to have the electrical terminals on the front and back of the solar cell. This standard interconnection scheme needs some space which is a loss of irradiated area in a dense array configuration. Therefore, interconnection schemes were investigated aiming for higher packaging factors in the dense array. The investigated options are front contacted solar cells, ${ }^{176}$ back contacted cells (metal wrap $\operatorname{around}^{177}$ or metal wrap through ${ }^{178}$ ), monolithic interconnected modules (MIMs), ${ }^{179-181}$ and interconnection by shingling cells. ${ }^{182}$ In Fig. 16, dense array receiver designs with different solar cells and interconnection schemes are shown. All of them were experimentally investigated in a $1 \mathrm{~m}^{2}$ mirror dish system.

For the heat exchanger in the dense array, a good thermal transfer can be achieved by providing a large surface area inside of the heat exchanger (i.e., providing several thin channels like in microchannel coolers $\left.{ }^{186,187}\right)$, fins, ${ }^{172}$ or coolers made of metal foam. ${ }^{188}$ Another approach is to provide high thermal convection coefficients as realized in impinging jet coolers ${ }^{189}$ (or also combined with microchannels ${ }^{190}$ ). Royne et al. ${ }^{191}$ show that thermal resistances of $2.3 \times 10^{-3}\left(\mathrm{~m}^{2} \mathrm{~K}\right) / \mathrm{W}$ to $1 \times 10^{-6}\left(\mathrm{~m}^{2} \mathrm{~K}\right) / \mathrm{W}$ can be reached with fluid heat exchangers. However, when selecting a cooler for CPV, heat exchangers with values lower than $10^{-5}\left(\mathrm{~m}^{2} \mathrm{~K}\right) / \mathrm{W}$ at $1000 \times$ concentration are recommended.
Another receiver design is proposed by Angel et al. ${ }^{192}$ and Stalcup et al. ${ }^{193}$ In their receiver, a ball lens is introduced as a secondary optic. Together with a tertiary reflective element, this allows certain separation of the cells in the dense array. Therefore, there is space between the solar cells for electrical interconnection and heat transfer. The approach was also suggested for a receiver in a CPV tower. ${ }^{194}$

Water is usually the cooling medium, which allows for maximum temperatures below $100^{\circ} \mathrm{C}$. However, the value of the thermal energy increases with higher temperatures. For example, temperatures above $400^{\circ} \mathrm{C}$ could also be used in a steam turbine process to produce electricity. Considering a $\mathrm{CPV}-\mathrm{T}$ system to provide $400^{\circ} \mathrm{C}$ temperatures, new challenges arise. First, the selection of the multi-junction solar cells structure: AlGaInP/GaAs dual-junction solar cells were suggested by Steiner et al. in Ref. 195 for these applications. Solar cell efficiencies of $15 \%$ at $1000 \times$ and $400^{\circ} \mathrm{C}$ have already been demonstrated experimentally with the potential of reaching $20 \% .{ }^{195}$ Still, high temperature stable electrical contacts and packaging technologies need to be developed for this challenging temperature level. The heat exchanger itself also needs to be adapted in order to be capable of running with thermal oil that is used in concentrated solar power (e.g., parabolic troughs) typically up to temperatures of $400^{\circ} \mathrm{C}$.

\section{Thermal design aspects in the CPV module: Size of solar cell and flux density and distribution}

The electrical performance of the solar cell depends on the operating temperature. If the temperature rises, the power output decreases. The main reason is a temperature dependent change in bandgap and therefore a decrease in voltage with increasing temperature. The temperature dependence of the solar cell performance is described by the temperature coefficient. It is dependent on the material composition but also on the concentration as the decrease is smaller for higher concentration. Temperature coefficients for triple-junction solar cells are well investigated. The temperature coefficient of efficiency $\mathrm{T}_{\mathrm{C}}(\eta)$ for lattice matched triple-junction solar cells at $25^{\circ} \mathrm{C}$ is about $-0.1 \%_{\text {rel }} / \mathrm{K}$ under concentration (e.g., in $-0.098 \%$ rel $/ \mathrm{K}$ at $200 \times$ in Ref. $196,-0.129$ at $500 \times,{ }^{197}$ or

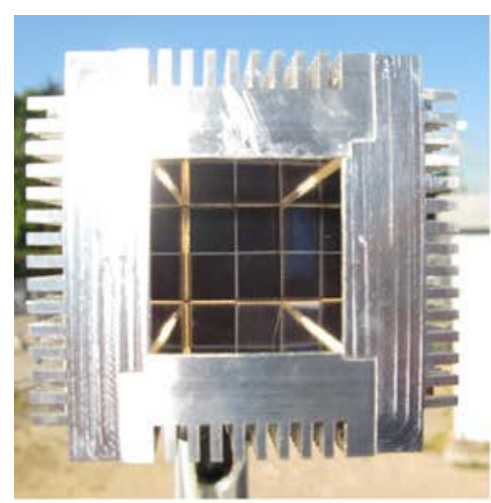

(a)

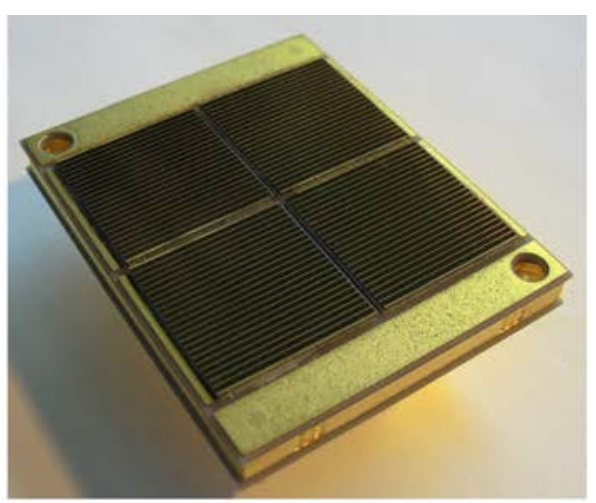

(b)

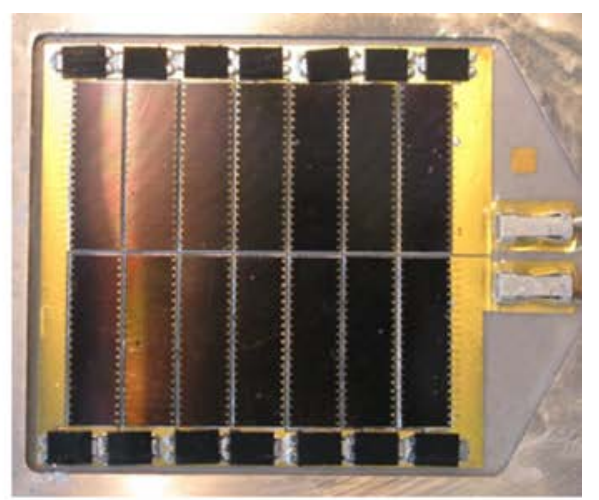

(c)

FIG. 16. Different designs for dense array receivers with different solar cell architectures. (a) Receiver with four $1 \mathrm{~cm}^{2}$ triple-junction solar cells as shown in Ref. 183 and reflective secondary optics for flux homogenization as well as increase in concentration. (b) Receiver with four $2.1 \times 2.1 \mathrm{~cm}{ }^{2}$ MIM (monolithic integrated module) cells and integrated bypass diode as presented in Ref. 93. (c) $14 \times 1.21 \mathrm{~cm}^{2}$ front side interconnected triple-junction solar cells as published in Ref. 176. The receivers were designed and investigated in a dish mirror with $1 \mathrm{~m}^{2} .{ }^{184,185}$ 
$-0.083 \%_{\text {rel }} / \mathrm{K}$ at $600 \times{ }^{198}$ ). For CPV-T applications with temperatures above $100^{\circ} \mathrm{C}$, Helmers et al. ${ }^{199}$ showed that the contribution to the electricity generation by the germanium subcell-usually used in a triple-junction solar cell-becomes insignificant. Solar cells with higher energy bandgaps than germanium become preferable for the lowest junction.

The thermal design of the modules aims to achieve the lowest possible solar cell operation temperatures in order to maximize the electrical performance and enhance reliability. Temperature and reliability are closely linked; as a rule of thumb, the Arrhenius equation predicts half lifetime with an operating temperature increase in only $10^{\circ} \mathrm{C}$. Solar cell operating temperatures should be below $95^{\circ} \mathrm{C}$ for 30 -yr warranty. ${ }^{200}$ Moreover, the design has to be reliable enough to withstand even higher than nominal operating temperatures, which occur during open voltage $\left(\mathrm{V}_{\mathrm{OC}}\right)$ conditions when no electricity is extracted and the thermal budget to the solar cell is at its maximum. The final thermal design depends on the illuminated area and solar cell size, flux distribution and intensity, and also the conditions of the heat transfer (conduction and convection). The thermal behavior is simulated and investigated with methods of thermal finite-element-modeling $(\mathrm{FEM})^{161}$ or computational fluid dynamics $(\mathrm{CFD})^{201}$ combined with optical ray tracing simulations. ${ }^{76} \mathrm{Jaus}$ et al. ${ }^{161}$ simulated the influence of the non-uniform flux distribution in a solar cell of a passively cooled module. In Ref. 202, he demonstrated that the temperature in the center of a $2.6 \times 2.6 \mathrm{~mm}^{2}$ cell absorbing $0.07 \mathrm{~W}$ is almost $15 \mathrm{~K}$ higher than at the edge of the cell. In Ref. 161, it was also demonstrated that at $\mathrm{V}_{\mathrm{OC}}$ condition in outdoor measurement in Freiburg, the cell operates around $70 \mathrm{~K}$ above ambient temperature.

\section{Encapsulation}

Solar cells need to be protected from mechanical damage and water which would lead to corrosion of the solar cell and electrical contacts. For dense array receivers, the solar cells can be protected by a glass plate glued to the receiver with transparent silicone. However, the edges of the receiver need to be further protected as dust could accumulate. The encapsulation must withstand the concentrated illumination. In lens-based modules, the solar cells are housed. Hermetic sealing is difficult to realize and maintain for a lifetime of more than $20 \mathrm{yr}$. The temperature variations in the real application cause pressure and slight volume changes in the module. To avoid these stress factors on the encapsulation of the module, today most modules are breathable after sealing and only protected from rain water, dust, and dirt. Still, the humidity in the module is a challenge since water condensation may occur. Therefore, in Ref. 17, Gombert et al. proposed an air-drying unit. The modules are actively flooded with dry air, thus avoiding water condensation inside the modules. Other modules protect the cells against humidity and only have a membrane to allow air exchange and protection from dust and water. ${ }^{203}$

In this context, it is noteworthy that refractive SOEs are beneficial to protect the solar cells. SOEs are glued directly onto the solar cell, thus the cell is completely sealed and protected against water condensation. Another interesting approach is presented by Rumyantsev et al. in Ref. 204 where the solar cells are glued to the glass baseplate from the rear side and thus fully protected.

\section{Designs for low module height and low focal distance}

The module height is a relevant design criterion. In passively cooled systems, the modules are usually assembled in the manufacturing facility and then shipped to the power plant. In this case for the reason for cost of transportation, the air volume and weight should be minimized.

Reflective optics are capable of providing shorter focal distances than refractive ones for the same aperture area (lower f-numbers), such as the already mentioned Cassegrain optics. ${ }^{38,47}$ In particular, concepts with non-imaging and light guiding optics can produce low modules, such as the XR concentrator-a concentrator with reflecting $(\mathrm{X})$ and freeform refracting (R) optics as shown in Ref. 32 by Plesniak et al. and Benitez et al. in Refs. 39 and 205. This approach leads to very flat modules. Low module heights can also be achieved with TIR optics as shown by Diaz in Refs. 206 and 207. Here, the primary optical element works by means of total internal reflection (TIR). The secondary optics work by refraction. Another concept is the SunSimba ${ }^{\mathrm{TM}}$ module from Morgan Solar ${ }^{208,209}$ where the light is guided laterally and therefore the modules are completely flat.

For refractive optics, the only approach for compact modules is to go to very small aperture areas of the elementary unit of the POE (micro concentration, see Sec. IIF). For the same opening angles, the focal distance will decrease linearly with the edge length of the POE. Keeping geometrical concentration constant also means a reduction in size of the solar cell.

\section{E. Reliability}

(C) PV modules are designed for a lifetime of 20 to $30 \mathrm{yr}$. To prove the stability of new developments, reliability is investigated by accelerated ageing tests in climate chambers. There, the performance of different components under defined stress is investigated. It is important to avoid superimposing of effects that prevent explicit characterization. Thus, testing on component level is required.

Qualification standards are developed within the working group WG7 as one of the working groups within the technical committee TC82 of the International Electrotechnical Commission (IEC). The participants and members are from industry and research institutes representing a broad spectrum of technologies and expertise. The first standard was published in 2007 with the IEC $62108^{6}$ for "Design qualification and type approval." In the testing procedure, the electrical, mechanical, and thermal performance of CPV modules is tested to prove that the module can withstand outdoor exposure. The major stress factors like changes in temperature, humid environment, or mechanical stress are tested. In addition, the ability to withstand high irradiation intensities is tested in the off-axis beam test and under outdoor exposure. However, the actual lifetime depends on specific design, production, environment, and 
the conditions under which the modules are operated. Today, a certification to the IEC 62108 standard is mandatory for CPV modules.

Regarding the solar cell, different solar cell structures have proven to be very stable. Especially for metamorphic buffer layers, a shift or growth of dislocations into active solar cell layers could be critical as high material quality is required. However, in extensive experiments, no difference between metamorphic and lattice matched solar cells could be observed. In the experiments at high humidity and temperature, oxidation of germanium and corrosion of the front side metallization occurred which is relevant for both structures. ${ }^{210,211}$

\section{F. Novel module designs}

Different design approaches and set-ups of the CPV components result in a huge variety of module designs. Here, two novel approaches are introduced briefly.

\section{Utilizing the diffuse irradiation}

CPV technology only utilizes direct radiation. Thus, the diffuse radiation is lost. Considering the standard spectrum AM1.5global with $1000 \mathrm{~W} / \mathrm{m}^{2}$ utilized in flat plate modules and the AM1.5d with $900 \mathrm{~W} / \mathrm{m}^{2}$ as the resource for a CPV module, the solar energy resource is $10 \%$ less for CPV compared to flat plate modules. In order to capture the diffuse radiation, special CPV module designs are under development. In these module designs, the direct solar radiation is concentrated onto a high efficiency multi-junction solar cell. The multi-junction solar cell is mounted on a silicon solar cell that utilizes the diffuse and spilled light that does not hit the multi-junction solar cell or substrate. Thus, the full global sun resource can be utilized. These module concepts were proposed in Refs. 212-214. Typical CPV locations have a DNI/GNI ratio above $0.85 .{ }^{215}$ With this concept of using the global irradiation, installation of CPV modules in areas with lower DNI/GNI (with GNI as the global normal irradiance) ratios becomes affordable. Yamada and Hirai showed in Ref. 214 an increase in power output of $39 \%$ for DNI/GNI around 0.75 for a module using triple-junction solar cells together with a bi-facial silicon solar cell. Martinez et al. showed in Ref. 216 that the silicon solar cell also works as a heat spreader and the metal distributor can be replaced. For this concept, bifacial silicon cells mounted to a glass rear plate are also suggested. In this way, additional radiation reflected by the ground can be utilized.

\section{Micro-CPV}

Micro-CPV is the miniaturization of the solar cell to an area of less than $1 \mathrm{~mm}^{2}$. Several module designs with small solar cells have been demonstrated ${ }^{60,214,217}$ reaching efficiencies of 35\%. ${ }^{218,219}$ Panasonic $^{217,219}$ uses PMMA lenses either directly attached to the solar cell (edge length of $970 \mu \mathrm{m}$ ) or with secondary optics and solar cell area of $0.672 \mathrm{~mm}^{2}$. Semprius uses SoG lenses with solar cells of $600 \mu \mathrm{m} .{ }^{60}$

The approach offers possibilities for new and potentially low cost manufacturing and assembly technologies as have been applied in large area display and micro light-emitting diode ( $\mu$ LED) technologies. Further progress and learning curves of those other technologies can be used. Module heights are low as the aperture size of the optics depends on the geometrical concentration and with the solar cell the focal distance decreases as well (constant $f$ number and $\mathrm{c}_{\text {geo }}$ ). This reduces cost for transportation, effort for handling and, with reduced weight, costs for balancing the system are lower. High optical efficiency can be achieved as full lenses are used omitting Fresnel lens losses from draft angles or tip roundings. Thermal management is also eased: solar cell temperatures are lower as the heat input per cell is reduced. Finally, due to low total current per cell, the electrical performance is less sensitive to nonuniformity of the flux distribution. ${ }^{50}$ Challenges are electrical losses in the solar cell that need to be regarded because of high perimeter to area ratio ${ }^{220}$ and possibly a higher percentage of shaded areas where dark currents induce losses. Additionally, many components need to be handled with high precision with placement in the micrometer range. This placement is required during the assembly but also needs to be maintained during operation where the positions can change due to thermal expansion. Alternatives for state of the art pick-and-place processes for mounting of the solar cell and wire bonding for the electrical contact need to be found. Parallelization of the process is possible as proposed by Semprius with the micro-transfer printing. ${ }^{221}$ Self-alignment processes using capillary, magnetitic, ${ }^{222}$ or electrostatic 223 processes are also possible on a research basis. More advanced is the fluidic self-assembly (FSA) process, where chips are transported stochastically by a fluid and then positioned on prepared, accurately manufactured tools for alignment. $^{224,225}$ In the process from Panasonic, the surface tension during the soldering process is applied. ${ }^{217}$ For parallel manufacturing of the front contacts (screen), printing, plating, or ink jet processes are feasible. Furthermore, solar cell structures with back contacted solar cells do not require a separate front contact and electrical interconnection can be realized with circuit boards. An overview of the status of micro-CPV technology is given by Dominguez et al. in Ref. 226.

\section{SYSTEM AND FIELD PERFORMANCE}

\section{A. Electrical performance}

The electrical performance is the most important characteristic of (C)PV modules. For this reason, for the electrical performance of various module technologies measured at different test labs, location at prevailing ambient conditions needs to be comparable. The standard 62670-1 and 62670-3 describe a methodology to measure the electrical performance of CPV modules in a standardized procedure. The standard ambient conditions for this electrical performance measurement are defined in IEC 62670-1. Besides spectral irradiance, wind speed, temperature, and direct normal irradiance (DNI) are the most important parameters in this standard. Given concentrator standard test conditions (CSTC), a DNI of $1000 \mathrm{~W} / \mathrm{m}^{2}, 25^{\circ} \mathrm{C}$ solar cell temperature and AM1.5d spectral irradiance, performance under concentrator standard operating conditions (CSOC) a DNI of $900 \mathrm{~W} / \mathrm{m}^{2}$, $20^{\circ} \mathrm{C}$ ambient temperature and AM1.5d spectral irradiance are defined. ${ }^{227}$ Multi-junction solar cells, widely used in CPV, exhibit higher dependency to spectral variations 


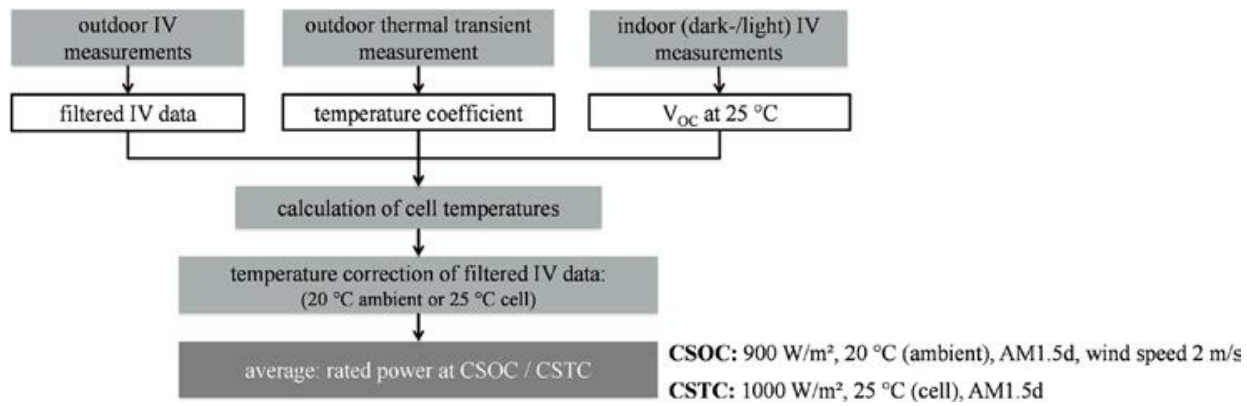

FIG. 17. Standardized measurement/ rating procedure for electrical performance of CPV modules according to IEC 62670-3 and Refs. 239 and 240. For concentrator standard test condition (CSTC), a DNI of $1000 \mathrm{~W} / \mathrm{m}^{2}$ and for concentrator standard operating conditions (CSOC), $900 \mathrm{~W} / \mathrm{m}^{2}$ are defined.

compared to silicon (and any single junction). CPV characterization procedures address this effect with a deeper control of the spectral irradiance. ${ }^{228,229}$ In the standard, the Spectral Matching Parameters (SMRs) ${ }^{229}$ were introduced in the 62670-3 to determine spectral prevailing conditions similar to the reference spectrum. These SMRs can be determined with simple sensors based on component cells. Components cells have the same optical characteristics as the multi-junction solar cell but with only one subcell electrically active. In Ref. 230, it was shown that the components cells of a lattice matched triple-junction solar cell can also be used for power rating of other cell types (e.g., metamorphic or four-junction solar cells) with no significant decrease in measurement uncertainty.

For indoor characterization of CPV modules with a sun simulator, CSTC is relevant. Next to the high irradiation of $1000 \mathrm{~W} / \mathrm{m}^{2}$, the irradiation has to be uniform on the measurement plane and requires the same collimation angle as sunlight. In addition, the spectrum needs to match the reference spectrum and the constant reference temperature $\left(25^{\circ} \mathrm{C}\right.$ cell temperature at CSTC). The requirement for the irradiance intensity and spectral irradiance is commonly achieved using illumination with a flash light on the focal spot of a paraboloidal mirror and measuring during a short period of a few milliseconds. ${ }^{231-234}$ Absolute irradiance level is determined by means of a reference device similar to the measured module (typically, a calibrated mono-module is used as reference sensor), while the spectral conditions are determined by means of component cells and SMRs parameters. ${ }^{235,236}$ The method is limited by the size of the mirror. As module areas up to $45 \mathrm{~m}^{2}$ (Ref. 237) have been presented, the stepwise measurement procedure was proposed and validated by Rapp et al. in Ref. 238 to characterize large area modules iteratively by illuminating module areas successively.

As an alternative to laboratory measurements, outdoor measurements are performed. Outdoor measurements are intended for CSOC. However, the measurements can be translated to CSTC. ${ }^{239}$ The procedure is defined in IEC 62670-3 and schematically shown in Fig. 17. Besides outdoor measurements of the module filtered for distinct ambient condition, the solar cell temperatures are determined with the temperature coefficient and the open circuit voltage at $25^{\circ} \mathrm{C}$. The open circuit voltage at $25^{\circ} \mathrm{C}$ is measured indoors with a sun simulator or derived from a dark IV measurement of the specimen.

The key advantage of CPV is the high electrical efficiency. In Fig. 18, the development and actual status on cell, module, and system efficiencies can be seen. The module efficiencies were measured outdoors until the measuring procedure was defined in IEC 62670 in 2014. Today, the highest efficiencies are $46.0 \%$ on cell level, ${ }^{4} 38.9 \%$ on module level, ${ }^{5}$ and $30 \%{ }^{60}$ on system level.

\section{B. Prediction of the power output}

Prediction of the performance of a specific module design under defined conditions is required to compare different designs. To simulate instantaneous power output, wavelengthdependent spectra are required. They can be simulated with "Simple Model of the Atmospheric Radiative Transfer of Sunshine" (SMARTS) ${ }^{242,243}$ to allow a detailed analysis of the performance under different spectral conditions. Input data for SMARTS2 are the aerosol optical depth and precipitable water. Models for simulating instantaneous (short-term) power output of CPV modules under realistic outdoor conditions including the solar cell architecture are Syracuse ${ }^{244}$ or YieldOpt. ${ }^{245}$

\section{Prediction of the energy yield and assessment of plant performance}

CPV technology provides high electrical efficiency. However, ultimately the yearly produced energy and the overall cost for a CPV power plant determine the economics. Therefore, a good prediction of the energy output of a

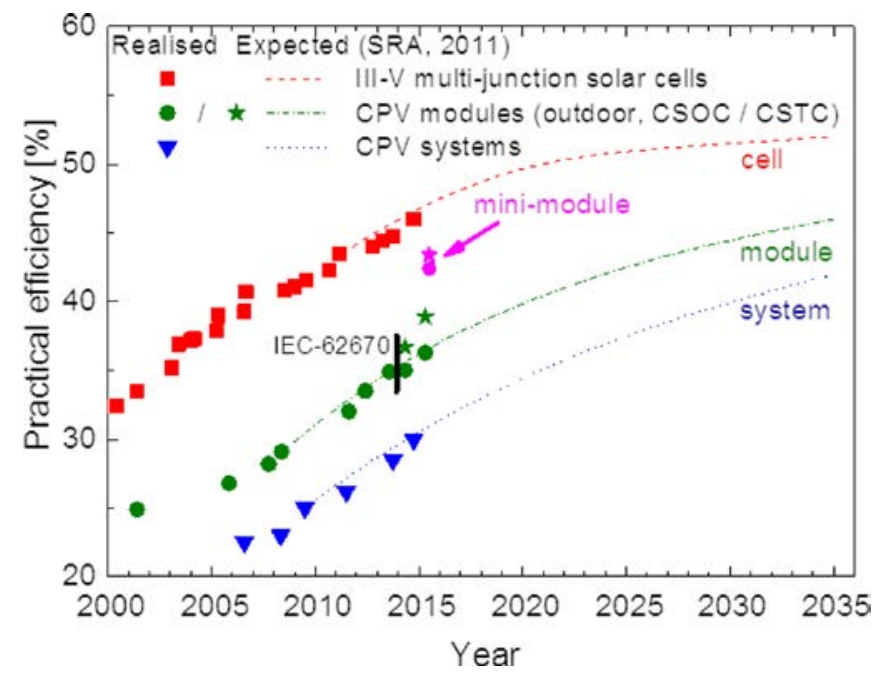

FIG. 18. Efficiency of solar cells, mini-module, modules, and systems. The symbols give the results that were achieved and published. CPV module measurements are distinguished between outdoor measurement conditions and CSTC measurements. The lines give the values from projections in 2011. ${ }^{241}$ The diagram also shows that the projections were very accurate. 
planned CPV power plant at a specific site is essential to determine the economics of a plant. ${ }^{18,246}$ Individual performance models based on field data combined with meteorological data from a specific site have been proposed in Ref. 247 for the Amonix module and in Ref. 60 for Semprius using SAPM by Sandia laboratory. ${ }^{248}$ Another open source model is the System Advisor Model (SAM) from NREL. In the software "PVSyst" developed at the University of Geneva to model the energy production of PV power plants, it is possible to consider the CPV specific requirements like DNI, spectrum, and temperature dependence. ${ }^{249,250}$ The available DNI at a dedicated plant location is the most crucial input parameter for an accurate prediction of the plant performance. As usually no long term measurements are available, data for a typical meteorological year (TMY) are assumed. There are different data sources with the widely used database Meteonorm ${ }^{251}$ (as worldwide data interpolated from weather stations) or TMY3 from NREL (derived from long-term measurements in the US) available.

Finally, to analyze the long term plant performance, the energy output based on electricity production and available energy (DNI) is monitored. The performance ratio (PR) as defined in IEC 61724-1 [Eq. (5)] describes the performance compared to the performance at CSTC. In Refs. 12, 20, and 252, average PRs between $75 \%$ and $89 \%$ are reported and in Ref. 252 PRs on module level reach between $90 \%$ and $95 \%$

$$
P R_{A C}=\frac{\text { measured AC energy } / D C \text { rated power at CSTC }}{\text { measured DNI energy } / 1 \mathrm{~kW} / \mathrm{m}^{2}} .
$$

The PR is usually below $100 \%$ as there are known losses because the module is not operated under STC conditions and ambient conditions vary depending on the site. In addition, operating solar cell temperature, shading between trackers, soiling, electricity conversion, and distribution (inverter, wiring, transformer), high wind loads and finally electricity self-consumption of the CPV system cause losses. There are other "CPV specific" losses due to temperature dependence of the SoG lens and changes in spectral conditions. $^{12,253}$ All these losses are anticipated and are included in the accurate prediction models. Including these losses with the utilization factor, prediction accuracy for AC power production of $<2 \%$ for a CPV site has been reported. ${ }^{250}$ To analyze the long term field performance, the performance index (PI) was introduced by Gerstmaier $e t a l$. in Ref. 240 and further detailed in Ref. 240 by comparing the actual with the expected energy production. By excluding the expected losses, the performance of an existing plant can be assessed easily. Evaluating three sites with installations from Soitec, PIs between $100 \%$ and $106 \%$ were reported. This means that the energy output of the plant exceeded the expectations.

\section{Maintenance incidence during operation of CPV plants}

It is important to understand failures in the field to introduce measures of prevention and better plans for maintenance works. For one of the oldest plants at ISFOC in Puertollano, analyzing maintenance work at the plant, most incidences occurred with the tracker (between 2008 and 2013). This can be explained by numerous mechanical parts. ${ }^{215,254}$ In Gerstmaier et al. ${ }^{12}$ failures of inverters are reported as the main cause for unavailability. Faster repairs are suggested to reduce failure time. This also means that no severe failures of main components occurred, only failures of mechanical parts and electronics that could be repaired.

\section{E. Long term stability—Durability}

Long term stability of CPV module performance is crucial for economical plant operation where 20 to $30 \mathrm{yr}$ are required. Long term data on the current module designs are limited as progress in development is fast. The qualification standard IEC 62108 so far gives good indication that systems perform well in the field if they have received the certification. ${ }^{8}$ Solar Systems, ${ }^{255}$ Soitec, ${ }^{12,18,256}$ Semprius, ${ }^{218}$ Suncore, ${ }^{10}$ and ISFOC from the plants in Puertollano ${ }^{8}$ and Daido Steel ${ }^{67}$ have shown performance data from 2 to $8 \mathrm{yr}$ with no degradation observed.

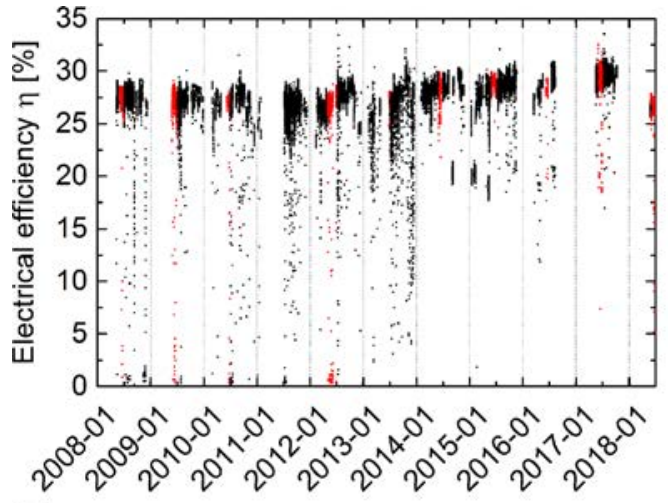

(a)

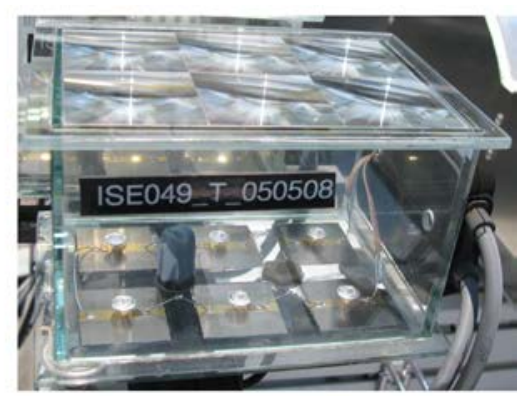

(b)

FIG. 19. (a) Measured electrical efficiency of the FLATCON ${ }^{\circledR}$ test-module ISE049_T. The module with 6 cell-lens units was assembled at Fraunhofer ISE with triple-junction solar cells and reflective secondary optics was installed on the test tracker in Freiburg, Germany, on 10/05/2008 and since then has been mounted and tracked though not continuously measured. Measurement data (till 26/06/2018) were filtered for DNI $>700 \mathrm{~W} / \mathrm{m}^{2}$, deviation of DNI $\pm 1 \%, 0$ $<\mathrm{V}_{\mathrm{MPP}} / \mathrm{V}_{\mathrm{OC}}<1$, and $0<\mathrm{I}_{\mathrm{MPP}} / \mathrm{I}_{\mathrm{SC}}<1$, DNI/GNI $>0.6$. Measurements during the month of June are shown in red. (b) Photograph of the FLATCON ${ }^{\circledR}$ testmodule on 25/05/2018 after $10 \mathrm{yr}$ of outdoor exposure. No degradation can be seen. 
A FLATCON ${ }^{\circledR}$ test-module with 6 cell-lens units and reflective secondary optics was mounted to a test tracker at Fraunhofer ISE in Freiburg, Germany. The initial performance of the module in 2008 is analyzed in detail by Jaus et al. in Refs. 85 and 257. As shown in Fig. 19(a), over the whole period of $10 \mathrm{yr}$, no decrease in electrical efficiency can be observed. In Fig. 19(b), a photo taken in May 2018 is shown. No degradation of the lens and solar cell assemblies can be visually detected.

\section{CONCLUSION}

The strength of CPV is the highest efficiencies for direct-normal irradiance. On the solar cell level, the highest efficiency is $46 \%$ for a solar cell with four pn-junctions and $38.9 \%$ measured on the module level at standardized CSTC conditions. High efficiencies mean that power per module area is lower and therefore the production facilities are smaller and less capital expenditure (CapEx) is required to build up production. In particular, as the semiconductor area in HCPV systems is reduced, the energy payback time can be as low as 0.7 to $1.5 \mathrm{yr}$ for CPV locations. ${ }^{258,259}$ The technology is especially suitable for high DNI regions above $2000 \mathrm{~kW} \mathrm{~h} / \mathrm{m}^{2} /$ year. The ambient temperatures in these locations are also usually high where CPV performs better compared to silicon PV because of low temperature coefficients and therefore lower losses due to temperatures. The application can be used from small systems to utility scale power plants. In actively cooled systems, thermal energy is generated that can be used for water heating or additional processes like desalination or solar cooling. In this type of system, the system efficiency can reach $75 \%$. Furthermore, it is important to involve the local community for good acceptance of the technology. In a CPV installation, the local content can be high for local manufacturing of parts, preparation of infrastructure, installation, and also operation and maintenance. As the structure of trackers is high, it is possible to use the land below for other purposes like agriculture. Shading by the modules can also be beneficial for growing plants in the arid regions.

Solar cells, optical elements, electrical contacts, heat distributors, and housing or encapsulation are needed to make a CPV module. Because of the optics, the module or several modules are assembled on a tracker that moves with the sun. Finally, for utility scale electricity production, many systems are interconnected in a plant. High efficiency multijunction solar cells are available. Currently, solar cells with more than three junctions are under development to increase the efficiency further. To combine the variety of mostly III$\mathrm{V}$ materials with different lattice constants, new processing technologies such as wafer bonding are being developed in addition to metamorphic concepts. New materials like silicon substrates are also used to reduce the costs. For the primary optics, the silicone-on-glass (SoG) Fresnel lenses are widely used. Different designs for secondary optics have been investigated. Depending on the design implementing secondary optics, the geometrical concentration or the acceptance angle $(C A P)$ can be increased. With other designs, the flux distribution on the solar cell is homogenized. An ongoing research topic is the development of new approaches like achromatic lenses to overcome the chromatic aberration in lenses. All components in a CPV module need to match well for the overall best system performance. This is complex but well understood. For example, it is important to consider the temperature dependence of optical efficiency especially for SoG lenses.

$\mathrm{CPV}$ is a young technology making huge progress in the past 15 years. Even though first CPV systems were developed in the 1970s, until the years 2005 to 2008 only few systems were demonstrated, mainly by research groups or startup companies. Then, multi-junction solar cells became commercially available and the market started to increase. Unfortunately, the market has decreased since 2012 with declining prices for flat plate PV as the competing technology. There is large potential to further reduce the cost. Increase of efficiency and introduction of new manufacturing methods are possible. One approach is to implement manufacturing technologies that are used in other products with similar requirements like the LED or display industry. This would require miniaturized solar cells and optics. Another approach is to increase efficiency (by improvement of the component designs like solar cells and optics) and also the energy yield of a CPV module. Both can be achieved by introducing secondary optics. The utilization of diffuse irradiation with silicon solar cells and multi-junction solar cells is also promising.

In CPV, there is a variety of system designs as components can be arranged and designed in different ways using different materials and technologies for manufacturing. For good comparison and also to verify reliability, the working group WG7 within the technical committee TC 82 of the IEC several has developed and finalized important standards in recent years. Recently, the IEC 62989 was published, where the characterization of optics is defined. The standard for power rating IEC 62670 is very important for comparison of performances of modules. Today, most commercial systems are certified to IEC 62108 which is an accepted method for proving reliability. Currently, to adapt this standard, a new standard for cells on carrier (COC) is about to be finished. Then, changing solar cells in a module will not require complete testing to IEC 62108 anymore. A standard for tracker qualification is also under development.

Finally, system installations in the field have shown reliable performances. In 2008, the first large installations in Puertollano with three different technologies were deployed. For the systems certified to IEC 62108, no degradation could be observed. In this paper, we also present a FLATCON ${ }^{\circledR}$ module that has been measured for $10 \mathrm{yr}$ and showed no degradation.

\section{ACKNOWLEDGMENTS}

The authors would like to thank colleagues and friends from the whole CPV community worldwide for their open discussion and intelligent research. Only in this way could the complex CPV technology be developed to a mature technology. We would like to thank our funding organizations. The work at Fraunhofer ISE and IES-UPM 
has been supported by many projects. This work was partly funded by the Federal Ministry for Economic Affairs and Energy (BMWi) under the HeKMod4 project, Contract No. 0325750. Last but not least, we would like to thank our colleagues at our institutes, particularly M. Steiner and J. Cordell for improving the paper with corrections. The authors are responsible for the content of this work.

${ }^{1}$ D. E. Arvizu, "Photovoltaic concentrator research progress," in Proceedings of the 18th IEEE Photovoltaic Specialists Conference (1985), pp. 1529-1536.

${ }^{2}$ H. Hayden, P. Johnston, V. Garboushian, and D. Roubideaux, "APS installation and operation of $300 \mathrm{~kW}$ of Amonix high concentration PV systems," in Proceedings of the 29th IEEE Photovoltaic Specialists Conference, Hyatt Regency New Orleans, New Orleans, Louisiana, 19-24 May 2002 (Institute of Electrical and Electronics Engineers, Piscataway, N.J., 2002), pp. 1362-1365.

${ }^{3}$ R. M. Swanson and R. A. Sinton, "Point contact silicon solar cells," in Proceedings of Seventh E.C. Photovoltaic Solar Energy Conference, edited by A. Goetzberger, W. Palz, and G. Willeke (Springer, Dordrecht, The Netherlands, 1987), pp. 742-748.

${ }^{4}$ F. Dimroth, T. N. D. Tibbits, M. Niemeyer, F. Predan, P. Beutel, C. Karcher, E. Oliva, G. Siefer, D. Lackner, P. Fus-Kailuweit, A. W. Bett, R. Krause, C. Drazek, E. Guiot, J. Wasselin, A. Tauzin, and T. Signamarcheix, "Four-junction wafer-bonded concentrator solar cells," IEEE J. Photovoltaics 6(1), 343-349 (2016).

${ }^{5}$ S. van Riesen, M. Neubauer, A. Boos, M. M. Rico, C. Gourdel, S. Wanka, R. Krause, P. Guernard, and A. Gombert, "New module design with 4-junction solar cells for high efficiencies," AIP Conf. Proc. 1679, 100006 (2015).

${ }^{6}$ IEC 82/429/CDV 62108 (International Electrotechnical Commission, 2006).

${ }^{7}$ F. Rubio, M. Martínez, D. Sánchez, and R. Aranda, "Results of three years CPV demonstration plants in ISFOC," in Proceedings of the 37th IEEE Photovoltaic Specialists Conference (PVSC) (IEEE, Piscataway, NJ, 2011).

${ }^{8}$ M. Martínez, D. Sánchez, G. Calvo-Parra, E. Gil, Á. Hipólito, F. de Gregorio, and O. de La Rubia, "8 years of CPV. ISFOC CPV plants, long-term performance analysis and results," AIP Conf. Proc. 1881, 020007 (2017).

${ }^{9}$ J. Foresi, A. Babej, R. Han, T. Liao, C. Wang, and D. King, "Suncore's CPV power plant deployment in western China," in Proceedings of the 40th IEEE Photovoltaic Specialists Conference (PVSC) (IEEE, Piscataway, NJ, 2014), pp. 3282-3286.

${ }^{10}$ J. Foresi, A. Babej, R. Han, T. Liao, and C. Wang, "Characterization of suncore's utility-scale CPV power plants,” AIP Conf. Proc. 1679, 30001 (2015).

${ }^{11}$ M. Wiesenfarth, S. P. Philipps, A. W. Bett, K. Horowitz, and S. R. Kurtz, Study: Current Status of Concentrator Photovoltaic (CPV) Technology, Version 1.3, see https://www.ise.fraunhofer.de/en/renewable-energydata.html\#faqitem_3-answer.

${ }^{12}$ T. Gerstmaier, T. Zech, M. Röttger, C. Braun, and A. Gombert, "Largescale and long-term CPV power plant field results," AIP Conf. Proc. 1679, 30002 (2015).

${ }^{13}$ M. Liu, R. Gordon, A. Plesniak, W. Bagienski, and V. Garboushian, "Performance analysis and modeling of the world's largest CPV power plant," in Proceedings of the 39th IEEE Photovoltaic Specialists Conference (PVSC) (IEEE, Piscataway, NJ, 2013), pp. 1749-1754.

${ }^{14}$ E. Lorenzo and G. Sala, "Hybrid silicone-glass Fresnel lens as concentrator for photovoltaic applications," in Sun II; Proceedings of the Silver Jubilee Congress, edited by K. W. Böer and B. H. Glenn (Pergamon Press, 1979), Vol. 1, pp. 536-539.

${ }^{15}$ V. D. Rumyantsev, V. M. Andreev, A. W. Bett, F. Dimroth, M. Hein, G. Lange, M. Z. Shvarts, and O. V. Sulima, "Progress in development of allglass terrestrial concentrator modules based on composite Fresnel lenses and III-V solar cells," in Proceedings of the 28th IEEE Photovoltaic Specialists Conference (IEEE, 2000), Vol. 1, pp. 1169-1172.

${ }^{16}$ J. S. Foresi, R. Hoffman, D. King, and P. Ponsardin, "Performance of silicone-on-glass Fresnel lenses in EMCORE's Gen 3 high-concentration concentrator photovoltaic system," Proc. SPIE 8468, 84680G (2012).

${ }^{17}$ A. Gombert, N. Abela, T. Gerstmeier, S. Bambrook, and F. Rubio, "Annex: Soitec power plants," in Handbook of Concentrator
Photovoltaic Technology, edited by C. Algora and I. Rey-Stolle (Wiley, Chichester, West Sussex, United Kingdom, 2016), pp. 513-520.

${ }^{18}$ J. Wüllner, M. Steiner, M. Wiesenfarth, and A. W. Bett, "Operation \& maintenance - The key for reliable performance in a CPV power plant," in Proceedings of the 14th International Conference on Concentrator Photovoltaic Systems (American Institute of Physics, Melville, N.Y., 2018).

${ }^{19}$ I. Luque-Heredia, P. Magalhães, and M. Muller, "CPV tracking and trackers," in Handbook of Concentrator Photovoltaic Technology, edited by C. Algora and I. Rey-Stolle (Wiley, Chichester, West Sussex, United Kingdom, 2016), pp. 293-338.

${ }^{20}$ Y. Abiko, R. Mikami, K. Iyatani, S. Tamura, K. Sugiyama, and M. Ueyama, "Evaluation of concentrator photovoltaic system power plant," SEI Tech. Rev. 86, 100-105 (2018).

${ }^{21}$ IEC, TS 62989:2018: Primary optics for concentrator photovoltaic systems (International Electrotechnical Commission, 2018).

${ }^{22}$ P. Benitez, J. C. Minano, P. Zamora, R. Mohedano, A. Cvetkovic, M. Buljan, J. Chaves, and M. Hernandez, "High performance Fresnel-based photovoltaic concentrator," Opt. Express 18(S1), A25-A40 (2010).

${ }^{23}$ R. Winston, "Nonimaging optics," Sci. Am. 264(3), 52-57 (1991).

${ }^{24}$ R. Mohedano and R. Leutz, "CPV optics," in Handbook of Concentrator Photovoltaic Technology, edited by C. Algora and I. Rey-Stolle (Wiley, Chichester, West Sussex, United Kingdom, 2016), pp. 187-238.

${ }^{25}$ R. L. Donovan, H. C. Hunter, J. T. Smith, R. L. Jones, and S. L. Broadbent, "Ten kilowatt photovoltaic concentrating array," in Proceedings of the 13th IEEE Photovoltaic Specialists Conference (1978), pp. 1125-1130.

${ }^{26}$ G. Sala, G. L. Araújo, A. Luque, J. M. Ruiz, A. Coello, E. Lorenzo, F. Chenlo, J. Sanz, and A. Alonso, "The Ramon Areces concentration photovoltaic array," in Proceedings of the Silver Jubilee Congress (1979), Vol. 3, pp. 1737-1741.

${ }^{27}$ C. J. Chiang and M. A. Quintana, "Sandia's CONCEPT-90 photovoltaic concentrator module," in Proceedings of the 21st IEEE Photovoltaic Specialists Conference (IEEE, 1990), pp. 887-891.

${ }^{28}$ D. Carroll, "Alpha Solarco's high-concentration photovoltaic array development program," in Proceedings of the 20th IEEE Photovoltaic Specialists Conference (IEEE, 1988), Vol. 2, pp. 1138-1143.

${ }^{29}$ V. Garboushian, D. Roubideaux, S. Yoon, and J. A. Gunn, “An evaluation of integrated high-concentration photovoltaics for large-scale grid connected applications," in Proceedings of the 25th IEEE Photovoltaic Specialists Conference (IEEE, New York, New York, USA, 1996), pp. 1373-1376.

${ }^{30}$ S. Askins, M. Victoria, R. Herrero, C. Domínguez, I. Antón, G. Sala, A. Coutinho, and J. C. Amador, "Optimization of tolerant optical systems for silicone on glass concentrators," AIP Conf. Proc. 1477, 327-330 (2012).

${ }^{31}$ A. W. Bett, B. Burger, F. Dimroth, G. Siefer, and H. Lerchenmüller, "High-concentration PV using III-V solar cells," in Proceedings of the 4th World Conference on Photovoltaic Energy Conversion (Institute of Electrical and Electronics Engineers, Piscataway, NJ, 2006), pp. 615-620.

${ }^{32}$ S. Askins, I. Antón, and G. Sala, IES-UPM Internal Report, 2010.

${ }^{33} \mathrm{~K}$. Araki, H. Uozumi, T. Egami, M. Hiramatsu, Y. Miyazaki, Y. Kemmoku, A. Akisawa, N. J. Ekins-Daukes, H. S. Lee, and M. Yamaguchi, "Development of concentrator modules with dome-shaped Fresnel lenses and triple-junction concentrator cells," Prog. Photovoltaics 13(6), 513-527 (2005).

${ }^{34}$ P. Zamora, P. Benítez, R. Mohedano, A. Cvetković, J. Vilaplana, Y. Li, M. Hernández, J. Chaves, and J. C. Miñano, "Experimental characterization of Fresnel-Köhler concentrators," J. Photonics Energy 2(1), 21806 (2012).

${ }^{35}$ A. Pereira, L. Dargent, G. Lorin, W. Schwartz, T. Baffie, C. Mangeant, M. Mariotto, J.-E. de Salins, and G. Vives, "Electro-optical study of a $\times 1024$ concentrator photovoltaic system," Prog. Photovoltaics 22(3), 383-393 (2014).

${ }^{36}$ K. Ghosal, D. Lilly, J. Gabriel, S. Seel, E. Menard, S. Burroughs, R. Daniel, S. Lowe, and C. Kudja, "Performance of a microcell based transfer printed HCPV system in the South Eastern US," in Proceedings of the 38th IEEE Photovoltaic Specialists Conference (PVSC) (IEEE, Piscataway, NJ, 2012), Vol. 1477, pp. 327-330.

${ }^{37}$ M. Victoria, C. Dominguez, S. Askins, I. Anton, and G. Sala, "Experimental analysis of a photovoltaic concentrator based on a single reflective stage immersed in an optical fluid," Prog. Photovoltaics 22(12), 1213-1225 (2014). 
${ }^{38}$ S. Horne, M. McDonald, N. Hartsoch, and K. Desy, "Reflective optics CPV panels enabling large scale, reliable generation of solar energy cost competitive with fossil fuels," Subcontract Report NREL/SR-520-47310, 15 November 2007-30 June 2009.

${ }^{39}$ A. Plesniak, R. Jones, J. Schwartz, G. Martins, J. Hall, A. Narayanan, D. Whelan, P. Benitez, J. C. Minano, A. Cvetkovic, M. Hernandez, O. Dross, and R. Alvarez, "High performance concentrating photovoltaic module designs for utility scale power generation," in Proceedings of the 34th IEEE Photovoltaic Specialists Conference (PVSC) (IEEE, 2009), pp. 2231-2236.

${ }^{40}$ D. D. Nardis, "A single reflection approach to HCPV: Very high concentration ratio and wide acceptance angles using low cost materials," AIP Conf. Proc. 1477, 94 (2012).

${ }^{41}$ V. Diaz, J. L. Alvarez, J. Alonso, A. Luque, and C. Mateos, "Towards a technology for mass production of very high concentration flat panels," in Proceedings of the 19th European Photovoltaic Solar Energy Conference (2004), pp. 2086-2089.

${ }^{42}$ M. Victoria Pérez, "New concepts and techniques for the development of high-efficiency concentrating photovoltaic modules," Ph.D. thesis (E.T.S.I. Telecomunicación, UPM, 2014).

${ }^{43} \mathrm{H}$. Ries and A. Rabl, "Edge-ray principle of nonimaging optics," J. Opt. Soc. Am. A 11(10), 2627 (1994).

${ }^{44} \mathrm{P}$. Zamora, "A high-performance photovoltaic concentrator," SPIE Newsroom (2010).

${ }^{45} \mathrm{H}$. Chayet, O. Kost, R. Moran, and I. Lozovsky, "Efficient, low cost dish concentrator for a CPV based cogeneration system," in Proceedings of IEEE Electrical Power \& Energy Conference (2011), Vol. 1407, pp. 249-252.

${ }^{46}$ K. Shanks, S. Senthilarasu, and T. K. Mallick, "Optics for concentrating photovoltaics. Trends, limits and opportunities for materials and design," Renewable Sustainable Energy Rev. 60, 394-407 (2016).

${ }^{47}$ S. Horne, G. Conley, J. M. Gordon, R. Fork, P. Meada, E. Schrader, and T. Zimmermann, "A solid 500 sun compound concentrator PV design," in Proceedings of the 4th World Conference on Photovoltaic Energy Conversion (Institute of Electrical and Electronics Engineers, Piscataway, NJ, 2006), pp. 695-697.

${ }^{48}$ L. Fraas, J. Avery, H. Huang, L. Minkin, and E. Shifman, "Demonstration of a 33\% efficient cassegrainian solar module," in Proceedings of the 21 st European Photovoltaic Solar Energy Conference (2006), Vol. 1, pp. 679-682.

${ }^{49}$ P. Benitez, A. Cvetkovic, R. Winston, V. Diaz, L. Reed, J. Cisneros, A. Ritschel, and J. Wright, "High-concentration mirror-based Kohler integrating system for tandem solar cells," in Proceedings of the 4th World Conference on Photovoltaic Energy Conversion (Institute of Electrical and Electronics Engineers, Piscataway, NJ, 2006), pp. 690-693.

${ }^{50} \mathrm{M}$. Wiesenfarth, S. Gamisch, P. Jakob, M. Steiner, and A. W. Bett, "Systematic design evaluation on the example of a concentrator photovoltaic module with mirror optics and passive heat dissipation," Prog. Photovoltaics 26(7), 460-472 (2018).

${ }^{51}$ A. Kribus, D. Kaftori, G. Mittelman, A. Hirshfeld, Y. Flitsanov, and A. Dayan, "A miniature concentrating photovoltaic and thermal system," Energy Convers. Manage. 47(20), 3582-3590 (2006).

${ }^{52}$ D. Faiman, "PETAL - The giant solar dish at Sede Boqer," Trans. ASME: J. Sol. Energy Eng. 126(3), 824-825 (2004).

${ }^{53}$ J. Lasich, I. Thomas, W. Hertaeg, D. Shirley, N. Faragher, N. Erenstrom, S. Carter, B. Cox, and X. Zuo, "A $200 \mathrm{~kW}$ central receiver CPV system," AIP Conf. Proc. 1679, 30004 (2015).

${ }^{54}$ C. K. Ho, C. A. Sims, and J. M. Christian, "Evaluation of glare at the Ivanpah Solar Electric Generating System," Energy Procedia 69, 1296-1305 (2015)

${ }^{55}$ G. Srilakshmi, V. Venkatesh, N. C. Thirumalai, and N. S. Suresh, "Challenges and opportunities for solar tower technology in India," Renewable Sustainable Energy Rev. 45, 698-709 (2015).

${ }^{56} \mathrm{~S}$. Schell, "Design and evaluation of esolar's heliostat fields," Sol. Energy 85(4), 614-619 (2011)

${ }^{57}$ R. Branke and A. Heimsath, "Raytrace3D-power tower - A novel optical model for central receiver systems," in Proceedings of 16th SolarPACES Conference (2010).

${ }^{58}$ J. B. Lasich, P. J. Verlinden, A. Lewandowski, D. Edwards, H. Kendall, S. Carter, I. Thomas, P. Wakeman, M. Wright, W. Hertaeg, R. Metzke, M. Daly, M. Santin, A. Neumann, A. Wilson, A. Caprihan, and M. Stedwell, "World's first demonstration of a $140 \mathrm{kWp}$ Heliostat Concentrator PV (HCPV) system," in Proceedings of the 34th IEEE Photovoltaic Specialists Conference (PVSC) (IEEE, 2009), p. 002275.
${ }^{59}$ O. Behar, A. Khellaf, and K. Mohammedi, "A review of studies on central receiver solar thermal power plants," Renewable Sustainable Energy Rev. 23, 12-39 (2013).

${ }^{60}$ K. Ghosal, D. Lilly, J. Gabriel, M. Whitehead, S. Seel, B. Fisher, J. Wilson, and S. Burroughs, "Semprius field results and progress in system development," IEEE J. Photovoltaics 4(2), 703-708 (2014).

${ }^{61}$ J. Foresi, "Annex: Suncore photovoltaics' CPV modules," in Handbook of Concentrator Photovoltaic Technology, edited by C. Algora and I. Rey-Stolle (Wiley, Chichester, West Sussex, United Kingdom, 2016), pp. 426-432.

${ }^{62}$ T. Luce and J. Cohen, "The path to volume production for CPV optics," in Proceedings of the 35th IEEE Photovoltaic Specialists Conference (PVSC) (IEEE, Piscataway, NJ, 2010), pp. 487-492.

${ }^{63}$ D. C. Miller and S. R. Kurtz, "Durability of Fresnel lenses. A review specific to the concentrating photovoltaic application," Sol. Energy Mater. Sol. Cells 95(8), 2037-2068 (2011).

${ }^{64}$ A. Nayak, G. S. Kinsey, M. Liu, W. Bagienski, and V. Garboushian, "Comparison of primary optics in amonix CPV arrays," AIP Conf. Proc. 1477, 77-80 (2012).

${ }^{65}$ B. Fassbender, P. Battenhausen, U. Löffler, J. Ackermann, P. Colburn, and P. A. Marks, "Reliability of PMMA for CPV lens applications," in Proceedings of the ISES Solar World Congress 2011, edited by K. Vajen (International Solar Energy Society, Freiburg, Germany, 2011), pp. 1-11. ${ }^{66} \mathrm{~K}$. Araki, M. Kondo, H. Uozumi, Y. Kemmoku, T. Egami, M. Hiramatus, Y. Miyazaki, N. J. Ekins-Daukes, M. Yamaguchi, G. Siefer, and A. W. Bett, "A 28\% efficient, $400 \times$ and $200 \mathrm{Wp}$ concentrator module," in Proceedings of the 19th European Photovoltaic Solar Energy Conference (2004), pp. 2495-2498.

${ }^{67} \mathrm{~K}$. Araki, "Annex: CPV modules and systems from daido steel," in Handbook of Concentrator Photovoltaic Technology, edited by C. Algora and I. Rey-Stolle (Wiley, Chichester, West Sussex, United Kingdom, 2016), pp. 413-418.

${ }^{68}$ H. Arase, A. Matsushita, A. Itou, T. Asano, N. Hayashi, D. Inoue, R. Futakuchi, K. Inoue, T. Nakagawa, M. Yamamoto, E. Fujii, Y. Anda, H. Ishida, T. Ueda, O. Fidaner, M. Wiemer, and D. Ueda, "A novel thin concentrator photovoltaic with micro solar cells directly attached to a lens array," IEEE J. Photovoltaics 4(2), 709-712 (2013).

${ }^{69}$ V. D. Rumyantsev, M. Hein, V. M. Andreev, A. W. Bett, F. Dimroth, G. Lange, G. Letay, M. Z. Shvarts, and O. V. Sulima, "Concentrator array based on GaAs cells and Fresnel lens concentrators," in Proceedings of the 16th European Photovoltaic Solar Energy Conference (James \& James, London, 2000), Vol. 3, pp. 2312-2315.

${ }^{70}$ T. Schult, M. Neubauer, Y. Bessler, P. Nitz, and A. Gombert, "Temperature dependence of Fresnel lenses for concentrating photovoltaics," in Proceedings of 2nd International Workshop on Concentrating Photovoltaic Power Plants: Optical Design and Grid Connection (2009).

${ }^{71}$ V. D. Rumyantsev, N. Y. Davidyuk, E. A. Ionova, P. V. Pokrovskiy, N. A. Sadchikov, V. M. Andreev, A. W. Bett, R. D. McConnell, G. Sala, and F. Dimroth, "Thermal regimes of Fresnel lenses and cells in 'all-glass' HCPV modules," AIP Conf. Proc. 1277, 89-92 (2010).

${ }^{72}$ T. D. Hornung, A. Bachmaier, P. Nitz, and A. Gombert, "Temperature dependent measurement and simulation of Fresnel lenses for concentrating photovoltaics," AIP Conf. Proc. 1277, 85-88 (2010).

${ }^{73}$ S. Askins, M. Victoria, R. Herrero, C. Domínguez, I. Antón, G. Sala, F. Dimroth, S. R. Kurtz, and A. W. Bett, "Effects of temperature on hybrid lens performance," AIP Conf. Proc. 1407, 57-60 (2011).

${ }^{74}$ T. D. Hornung, M. Neubauer, A. Gombert, P. Nitz, F. Dimroth, S. R. Kurtz, G. Sala, and A. W. Bett, "Fresnel lens concentrator with improved thermal behavior," AIP Conf. Proc. 1407, 66-69 (2011).

${ }^{75}$ T. D. Hornung, "Ein- und mehrstufige optische Konzentratoren für photovoltaische Anwendungen," Ph.D. thesis (Albert-Ludwigs-Universität, 2013).

${ }^{76}$ T. D. Hornung, M. Steiner, and P. Nitz, "Estimation of the influence of Fresnel lens temperature on energy generation of a concentrator photovoltaic system," Sol. Energy Mater. Sol. Cells 99, 333-338 (2012).

${ }^{77}$ I. García, M. Victoria, and I. Antón, "Temperature effects on CPV solar cells, optics and modules," in Handbook of Concentrator Photovoltaic Technology, edited by C. Algora and I. Rey-Stolle (Wiley, Chichester, West Sussex, United Kingdom, 2016), pp. 245-292.

${ }^{78}$ E. Hecht, Optics, 4th ed. (Addison-Wesley, Reading, Mass., 2002).

${ }^{79}$ F. Languy, K. Fleury, C. Lenaerts, J. Loicq, D. Regaert, T. Thibert, and S. Habraken, "Flat Fresnel doublets made of PMMA and PC. Combining 
low cost production and very high concentration ratio for CPV," Opt. Express 19(Suppl 3), A280-A294 (2011).

${ }^{80}$ G. Vallerotto, M. Victoria, S. Askins, R. Herrero, C. Domínguez, I. Antón, and G. Sala, "Design and modeling of a cost-effective achromatic Fresnel lens for concentrating photovoltaics," Opt. Express 24(18), A1245-A1256 (2016).

${ }^{81}$ G. Vallerotto, M. Victoria, S. Askins, I. Antón, and G. Sala, "Experimental characterization of achromatic doublet on glass (ADG) Fresnel lenses," AIP Conf. Proc. 1881, 30010 (2017).

${ }^{82}$ R. Herrero, M. Victoria, C. Domínguez, S. Askins, I. Antón, and G. Sala, "Understanding causes and effects of non-uniform light distributions on multi-junction solar cells. Procedures for estimating efficiency losses," AIP Conf. Proc. 1679, 050006 (2015).

${ }^{83}$ M. Victoria, R. Herrero, C. Domínguez, I. Antón, S. Askins, and G. Sala, "Characterization of the spatial distribution of irradiance and spectrum in concentrating photovoltaic systems and their effect on multi-junction solar cells," Prog. Photovoltaics 21(3), 308-318 (2013).

${ }^{84}$ C. Domínguez, I. Antón, G. Sala, and S. Askins, "Current-matching estimation for multijunction cells within a CPV module by means of component cells," Prog. Photovoltaics 21(7), 1478-1488 (2013).

${ }^{85}$ J. Jaus, A. W. Bett, H. Reinecke, and E. R. Weber, "Reflective secondary optical elements for Fresnel lens based concentrator modules," Prog. Photovoltaics 19, 580-590 (2011)

${ }^{86}$ M. Victoria, C. Domínguez, I. Antón, and G. Sala, "Comparative analysis of different secondary optical elements for aspheric primary lenses," Opt. Express 17(8), 6487-6492 (2009).

${ }^{87}$ E. Menard, M. Sullivan, J. Wilson, B. Fisher, S. Seel, M. Meitl, K. Ghosal, and S. Burroughs, "Optics development for micro-cell based CPV modules," Proc. SPIE 8108, 810805 (2011).

${ }^{88}$ T. Schmid, M. Wiesenfarth, T. D. Hornung, M. Gremmelspacher, P. Manns, and P. Nitz, "Mass manufactured secondary optics for CPV," AIP Conf. Proc. 1616, 84-87 (2014).

${ }^{89}$ M. Wiesenfarth, T. Dörsam, F. Eltermann, T. D. Hornung, G. Siefer, M. Steiner, S. van Riesen, M. Neubauer, A. Boos, S. Wanka, A. Gombert, and A. W. Bett, "CPV module with Fresnel lens primary optics and homogenizing secondary optics,” AIP Conf. Proc. 1679, 100007 (2015).

${ }^{90}$ L. Fu, R. Leutz, and H. P. Annen, "Secondary optics for Fresnel lens solar concentrators," Proc. SPIE 7785, 778509 (2010).

${ }^{91}$ X. Ning, R. Winston, and J. O'Gallagher, "Dielectric totally internally reflecting concentrators," Appl. Opt. 26(2), 300-305 (1987).

${ }^{92}$ J. Nilsson, R. Leutz, and B. Karlsson, "Improving asymmetrical CPCS for photovoltaics by using microstructured reflectors," in Proceedings of the 19th European Photovoltaic Solar Energy Conference (2004), pp. 2094-2097.

${ }^{93}$ H. Helmers, W. Y. Thor, T. Schmidt, D. W. van Rooyen, and A. W. Bett, "Optical analysis of deviations in a CPV central receiver system with a flux homogenizer," Appl. Opt. 52(13), 2974-2984 (2013).

${ }^{94}$ R. Löckenhoff, T. Kubera, and K. D. Rasch, "Water cooled TJ dense array modules for parabolic dishes," AIP Conf. Proc. 1277, 43-46 (2010).

${ }^{95}$ J. Jaus, P. Nitz, G. Peharz, G. Siefer, T. Schult, O. Wolf, M. Passig, T. Gandy, and A. W. Bett, "Second stage reflective and refractive optics for concentrator photovoltaics," in Proceedings of the 33rd IEEE Photovoltaic Specialists Conference (IEEE, 2008), pp. 1-5.

${ }^{96} \mathrm{~A}$. Mohr, T. Roth, and S. W. Glunz, "BICON. High concentration PV using one-axis tracking and silicon concentrator cells," Prog. Photovoltaics 14(7), 663-674 (2006).

${ }^{97}$ G. Sala, D. Pachon, J. Leloux, M. Victoria, A. W. Bett, P. Banda, A. Gombert, V. Diaz, M. A. Vazquez, A. El Moussaoui, and F. A. Abulfotuh, "NACIR. An European initiative dedicated to cooperation with mediterranean partner countries in the field of photovoltaic concentration," in Proceedings of the 24th European Photovoltaic Solar Energy Conference (2009), pp. 819-822.

${ }^{98}$ M. Victoria, S. Askins, I. Antón, G. Sala, and G. Duggan, "Temperature effects on two-stage optics made of silicone," AIP Conf. Proc. 1616, 92-96 (2014).

${ }^{99}$ F. Dimroth, C. Baur, A. W. Bett, K. Volz, and W. Stolz, "Comparison of dilute nitride growth on a single- and 8x4-inch multiwafer MOPVE system for solar cell applications," J. Cryst. Growth 272(1-4), 726-731 (2004)

${ }^{100}$ D. J. Friedman, J. F. Geisz, S. R. Kurtz, and J. M. Olson, “1-eV solar cells with GaInNAs active layer," J. Cryst. Growth 195(1-4), 409-415 (1998).

${ }^{101} \mathrm{G}$. Létay, C. Baur, and A. W. Bett, "Theoretical investigations of III-V multi-junction concentrator cells under realistic spectral conditions," in
Proceedings of the 19th European Photovoltaic Solar Energy Conference (2004), pp. 187-190.

${ }^{102}$ M. W. Wanlass, S. P. Ahrenkiel, R. K. Ahrenkiel, D. S. Albin, J. J. Carapella, A. Duda, J. F. Geisz, S. R. Kurtz, T. Moriarty, R. J. Wehrer, and B. Wernsman, "Lattice-mismatched approaches for highperformance, III-V photovoltaic energy converters," in Proceedings of the 31st IEEE Photovoltaic Specialists Conference (IEEE, 2005), pp. $530-535$.

${ }^{103}$ L. M. Fraas and R. C. Knechtli, "Design of high efficiency monolithic stacked multijunction solar cells," in Proceedings of the 13th IEEE Photovoltaic Specialists Conference (1978), pp. 886-891.

${ }^{104}$ F. Dimroth, P. Lanyi, U. Schubert, and A. W. Bett, "MOVPE grown Ga1xInxAs solar cells for GaInP/GaInAs tandem applications," J. Electron. Mater. 29(1), 42-46 (2000).

${ }^{105}$ R. R. King, M. Haddad, T. Isshiki, P. Colter, J. Ermer, H. Yoon, D. E. Joslin, and N. H. Karam, "Metamorphic GaInP/GaInAs/Ge solar cells," in Proceedings of the 28th IEEE Photovoltaic Specialists Conference (IEEE, 2000), pp. 982-985.

${ }^{106}$ A. W. Bett, C. Baur, F. Dimroth, and J. Schöne, "Metamorphic GaInPGaInAs layers for photovoltaic applications," in MRS Proceedings (Symposium L - Materials for Photovoltaics) Vol. 836, pp. 223-234.

${ }^{107}$ W. Guter, J. Schöne, S. P. Philipps, M. Steiner, G. Siefer, A. Wekkeli, E. Welser, E. Oliva, A. W. Bett, and F. Dimroth, "Current-matched triplejunction solar cell reaching $41.1 \%$ conversion efficiency under concentrated sunlight," Appl. Phys. Lett. 94(22), 223504 (2009).

${ }^{108}$ A. W. Bett, S. P. Philipps, S. Essig, S. Heckelmann, R. Kellenbenz, V. Klinger, M. Niemeyer, D. Lackner, and F. Dimroth, "Overview about technology perspectives for high efficiency solar cells for space and terrestrial applications," in Proceedings of the 28th European Photovoltaic Solar Energy Conference and Exhibition (WIP-Renewable Energies, Munich, Germany, 2013), pp. 1-6.

${ }^{109}$ S. P. Philipps, F. Dimroth, and A. W. Bett, "High-efficiency III-V multijunction solar cells," in McEvoy's Handbook of Photovoltaics. Fundamentals and Applications, 3rd ed., edited by S. A. Kalogirou (Academic Press, London, 2018), pp. 439-472.

${ }^{110}$ R. R. King, D. C. Law, K. M. Edmondson, C. M. Fetzer, G. S. Kinsey, H. Yoon, R. A. Sherif, and N. H. Karam, " $40 \%$ efficient metamorphic GaInP/GaInAs/Ge multijunction solar cells," Appl. Phys. Lett. 90, 183516 (2007).

${ }^{111}$ J. F. Geisz, D. J. Friedman, J. S. Ward, A. Duda, W. J. Olavarria, T. E. Moriarty, J. T. Kiehl, M. J. Romero, A. G. Norman, and K. M. Jones, " $40.8 \%$ efficient inverted triple-junction solar cell with two independently metamorphic junctions," Appl. Phys. Lett. 93(12), 123505 (2008).

${ }^{112}$ K. Sasaki, T. Agui, K. Nakaido, N. Takahashi, R. Onitsuka, and T. Takamoto, "Development of InGaP/GaAs/InGaAs inverted triple junction concentrator solar cells," AIP Conf. Proc. 1556, 22-25 (2013).

${ }^{113}$ R. M. France, J. F. Geisz, I. Garcia, M. Steiner, W. E. McMahon, D. J. Friedman, T. E. Moriarty, C. Osterwald, J. Scott Ward, A. Duda, M. Young, and W. J. Olavarria, "Quadruple-junction inverted metamorphic concentrator devices," IEEE J. Photovoltaics 5(1), 432-437 (2015).

${ }^{114}$ M. A. Green, Y. Hishikawa, E. D. Dunlop, D. H. Levi, J. Hohl-Ebinger, and A. W. Y. Ho-Baillie, "Solar cell efficiency tables (version 51)," Prog. Photovoltaics 26(1), 3-12 (2018).

${ }^{115}$ K. Derendorf, S. Essig, E. Oliva, V. Klinger, T. Roesener, S. P. Philipps, J. Benick, M. Hermle, M. Schachtner, G. Siefer, W. Jäger, and F. Dimroth, "Fabrication of GaInP/GaAs//Si solar cells by surface activated direct wafer bonding," IEEE J. Photovoltaics 3(4), 1423-1428 (2013).

${ }^{116}$ M. M. R. Howlader, P. R. Selvaganapathy, and M. J. Deen, "Nanobonding technology toward electronic, fluidic, and photonic systems integration," IEEE J. Sel. Top. Quantum Electron. 17(3), 689-703 (2011).

${ }^{117}$ M. Niemeyer, V. Klinger, F. Dimroth, F. Predan, P. Fuss-Kailuweit, D. Reinwand, D. Lackner, A. Wekkeli, E. Oliva, M. Schachtner, G. Siefer, and A. W. Bett, "Next generation of wafer-bonded multi-junction solar cells," in Proceedings of the 29th European PV Solar Energy Conference and Exhibition (WIP, München, 2014), pp. 1991-1995.

${ }^{118}$ M. Steiner, G. Siefer, T. Schmidt, M. Wiesenfarth, F. Dimroth, and A. W. Bett, "43\% sunlight to electricity conversion efficiency using CPV," IEEE J. Photovoltaics 6(4), 1020-1024 (2016).

${ }^{119}$ K. Zahraman, J. C. Guillaume, G. Nataf, B. Beaumont, M. Leroux, P. Gibart, and J. P. Faurie, "Epitaxial lift-off in photovoltaics: Ultra thin Al/ sub $0.2 / \mathrm{Ga} / \mathrm{sub} 0.8 / \mathrm{As}$ cell in a mechanically stacked $(\mathrm{Al}, \mathrm{Ga}) \mathrm{As} / \mathrm{Si}$ tandem," in Proceedings of the 24th IEEE Photovoltaic Specialists Conference (IEEE, 1994), Vol. 2, pp. 1898-1901. 
${ }^{120}$ J. J. Schermer, G. J. Bauhuis, P. Mulder, W. J. Meulemeesters, E. Haverkamp, M. M. A. J. Voncken, and P. K. Larsen, "High rate epitaxial lift-off of InGaP films from GaAs substrates," Appl. Phys. Lett. 76(15), 2131-2133 (2000).

${ }^{121}$ M. Konagai, M. Sugimoto, and K. Takahashi, "High efficiency GaAs thin film solar cells by peeled film technology," J. Cryst. Growth 45(1), 277-280 (1978)

${ }^{122}$ E. Yablonovitch, T. Gmitter, J. P. Harbison, and R. Bhat, "Extreme selectivity in the liftoff of epitaxial GaAs films," Appl. Phys. Lett. 51(26), 2222-2224 (1987)

${ }^{123}$ G. J. Bauhuis, P. Mulder, E. J. Haverkamp, J. J. Huijben, and J. J. Schermer, "26.1\% thin-film GaAs solar cell using epitaxial lift-off," Sol. Energy Mater. Sol. Cells 93(9), 1488-1491 (2009).

${ }^{124}$ B. M. Kayes, H. Nie, R. Twist, S. G. Spruytte, F. Reinhardt, I. G. Kizilyalli, and G. S. Higashi, " $27.6 \%$ conversion efficiency, a new record for single-junction solar cells under 1 sun illumination," in Proceedings of the 37th IEEE Photovoltaic Specialists Conference (PVSC) (IEEE, Piscataway, NJ, 2011), pp. 4-8.

${ }^{125}$ J. Adams, V. Elarde, A. Hains, C. Stender, F. Tuminello, C. Youtsey, A. Wibowo, and M. Osowski, "Demonstration of multiple substrate reuses for inverted metamorphic solar cells," in Proceedings of the 38th IEEE Photovoltaic Specialists Conference (PVSC) (IEEE, Piscataway, NJ, 2012), pp. 1-6.

${ }^{126}$ T. Takamoto, E. Ikeda, T. Agui, H. Kurita, T. Tanabe, S. Tanaka, H. Matsubara, Y. Mine, S. Takagishi, and M. Yamaguchi, "InGaP/GaAs and InGaAs mechanically-stacked triple-junction solar cells," in Proceedings of the 26th IEEE Photovoltaic Specialists Conference (IEEE, 1997), pp. 1031-1034.

${ }^{127}$ A. W. Bett, C. Baur, R. Beckert, F. Dimroth, G. Létay, M. Hein, M. Meusel, S. van Riesen, U. Schubert, G. Siefer, O. V. Sulima, and T. N. D. Tibbits, "Development of high-efficiency mechanically stacked GaInP/ GaInAs-GaSb triple-junction concentrator solar cells," in Proceedings of the 17th European Photovoltaic Solar Energy Conference and Exhibition (WIP-Renewable Energies [u.a.], München [u.a.], 2001), Vol. 1, pp. 84-87.

${ }^{128}$ S. Essig, C. Allebé, T. Remo, J. F. Geisz, M. Steiner, K. Horowitz, L. Barraud, J. S. Ward, M. Schnabel, A. Descoeudres, D. L. Young, M. Woodhouse, M. Despeisse, C. Ballif, and A. Tamboli, "Raising the onesun conversion efficiency of III-V/Si solar cells to $32.8 \%$ for two junctions and $35.9 \%$ for three junctions," Nat. Energy 2, 17144 (2017).

${ }^{129}$ M. P. Lumb, K. J. Schmieder, M. González, S. Mack, M. K. Yakes, M. Meitl, S. Burroughs, C. Ebert, M. F. Bennett, D. V. Forbes, X. Sheng, J. A. Rogers, and R. J. Walters, "Realizing the next generation of CPV cells using transfer printing," AIP Conf. Proc. 1679, 40007 (2015).

${ }^{130}$ L. Zhao, G. Flamand, Y. Mols, J. van der Heide, and J. Poortmans, "Novel mechanically stacked multi-junction solar cells applying ultrathin III-V cells and wafer based germanium cell," ECS Trans. 27(1), 1123-1128 (2010).

${ }^{131}$ X. Sheng, C. A. Bower, S. Bonafede, J. W. Wilson, B. Fisher, M. Meitl, H. Yuen, S. Wang, L. Shen, A. R. Banks, C. J. Corcoran, R. G. Nuzzo, S. Burroughs, and J. A. Rogers, "Printing-based assembly of quadruplejunction four-terminal microscale solar cells and their use in highefficiency modules," Nat. Mater. 13(6), 593 (2014).

${ }^{132}$ V. Sabnis, H. Yuen, and M. Wiemer, "High-efficiency multijunction solar cells employing dilute nitrides," AIP Conf. Proc. 1477, 14-19 (2012).

${ }^{133}$ F. Dimroth, M. Meusel, C. Baur, A. W. Bett, and G. Strobl, "3-6 junction photovoltaic cells for space and terrestrial concentrator applications," in Proceedings of the 31 st IEEE Photovoltaic Specialists Conference (IEEE, 2005), pp. 525-529.

${ }^{134}$ R. R. King, A. Boca, W. Hong, X.-Q. Liu, D. Bhusari, D. Larrabee, K. M. Edmondson, D. C. Law, C. M. Fetzer, S. Mesropian, and N. H. Karam, "Band-gap-engineered architectures for high-efficiency multijunction concentrator solar cells," in Proceedings of the 24th European Photovoltaic Solar Energy Conference (2009), pp. 55-61.

${ }^{135}$ S. Essig, E. Stämmler, S. Rönsch, E. Oliva, M. Schachtner, G. Siefer, A. W. Bett, and F. Dimroth, "Dilute nitrides for 4- and 6- junction space solar cells," in Proceedings of 9th European Space Power Conference (ESA, 2011), p. 6.

${ }^{136}$ F. Dimroth, S. P. Philipps, G. Peharz, E. Welser, R. Kellenbenz, T. Roesener, V. Klinger, E. Oliva, M. Steiner, M. Meusel, W. Guter, and A. W. Bett, "Promises of advanced multi-junction solar cells for the use in CPV systems," in Proceedings of the 35th IEEE Photovoltaic Specialists Conference (PVSC) (IEEE, Piscataway, NJ, 2010), pp. 123-136.
${ }^{137}$ S. Essig, J. Benick, M. Schachtner, A. Wekkeli, M. Hermle, and F. Dimroth, "Wafer-bonded GaInP/GaAs//Si solar cells with $30 \%$ efficiency under concentrated sunlight," IEEE J. Photovoltaics 5(3), 977-981 (2015).

${ }^{138}$ M. Steiner, G. Siefer, and A. W. Bett, "An investigation of solar cell interconnection schemes within CPV modules using a validated temperature-dependent SPICE network model," Prog. Photovoltaics 22(5), 505-514 (2014).

${ }^{139}$ M. Steiner, G. Siefer, and A. W. Bett, "SPICE network simulation to calculate thermal runaway in III-V solar cells in CPV modules," IEEE J. Photovoltaics 4(2), 749-754 (2014).

${ }^{140}$ M. Steiner, G. Siefer, and A. W. Bett, "Modeling the thermal runaway effect in CPV modules," AIP Conf. Proc. 1556, 230-233 (2013).

${ }^{141}$ N. Bosco, C. Sweet, T. J. Silverman, S. R. Kurtz, F. Dimroth, G. Sala, and A. W. Bett, "CPV cell infant mortality study," AIP Conf. Proc. 1407, 299-302 (2011).

${ }^{142} \mathrm{~J}$. W. Bishop, "Computer simulation of the effects of electrical mismatches in photovoltaic cell interconnection circuits," Sol. Cells 25(1), 73-89 (1988).

${ }^{143}$ I. Antón and G. Sala, "Losses caused by dispersion of optical parameters and misalignments in PV concentrators," Prog. Photovoltaics 13(4), 341-352 (2005).

${ }^{144}$ K. Araki, H. Nagai, R. Herrero, I. Antón, G. Sala, K.-H. Lee, and M. Yamaguchi, "1-D and 2-D Monte Carlo simulations for analysis of CPV module characteristics including the acceptance angle impacted by assembly errors," Sol. Energy 147, 448-454 (2017).

${ }^{145}$ R. Herrero, C. Domínguez, S. Askins, I. Antón, and G. Sala, "Twodimensional angular transmission characterization of CPV modules," Opt. Express 18(Suppl 4), A499-A505 (2010).

${ }^{146}$ R. Herrero, C. Domínguez, S. Askins, I. Antón, and G. Sala, "Luminescence inverse method For CPV optical characterization," Opt. Express 21(Suppl 6), A1028-A1034 (2013).

${ }^{147}$ R. Herrero, S. Askins, I. Antón, and G. Sala, "Evaluation of misalignments within a concentrator photovoltaic module by the module optical analyzer. A case of study concerning temperature effects on the module performance," Jpn. J. Appl. Phys., Part 1 54(8S1), 08 KE08 (2015).

${ }^{148}$ R. Herrero, I. Antón, M. Victoria, C. Domínguez, S. Askins, G. Sala, D. D. Nardis, and K. Araki, "Experimental analysis and simulation of a production line for CPV modules. Impact of defects, misalignments, and binning of receivers," Energy Sci. Eng. 5(5), 257-269 (2017).

${ }^{149}$ J. E. Noring, D. F. Grether, and A. J. Hunt, "Circumsolar radiation data. The Lawrence Berkeley laboratory reduced data base," Final subcontract report, Other Information: PBD: Dec 1991 NREL/TP-262-4429; LBL-29683; Other: ON: DE92001161 United States10.2172/ 10109904Other: ON: DE92001161Thu Jun 19 07:38:05 EDT 2008OSTI; NTIS; GPO Dep.NREL; SCA: 140100; SN: 92000622394English, 1991.

${ }^{150}$ A. Neumann, A. Witzke, S. A. Jones, and G. Schmitt, "Representative terrestrial solar brightness profiles," J. Sol. Energy Eng. 124(2), 198-204 (2002).

${ }^{151}$ V. M. Andreev, R. Romero, and O. V. Sulima, "An efficient circular contact grid for concentrator solar cells," Sol. Cells 11(3), 197-210 (1984).

${ }^{152}$ A. R. Moore, "An optimized grid design for a sun-concentrator solar cell,” RCA Rev. 40(2), 140-151 (1979).

${ }^{153}$ R. Herrero, M. Victoria, C. Domínguez, S. Askins, I. Antón, and G. Sala, "Concentration photovoltaic optical system irradiance distribution measurements and its effect on multi-junction solar cells," Prog. Photovoltaics 20(4), 423-430 (2012).

${ }^{154}$ M. Steiner, S. P. Philipps, M. Hermle, A. W. Bett, and F. Dimroth, "Front contact grid optimization of III-V solar cells with SPICE network simulation," in Proceedings of the 24th European Photovoltaic Solar Energy Conference (2009), pp. 721-725.

${ }^{155}$ M. Steiner, W. Guter, G. Peharz, S. P. Philipps, F. Dimroth, and A. W. Bett, "A validated SPICE network simulation study on improving tunnel diodes by introducing lateral conduction layers," Prog. Photovoltaics 20(3), 274-283 (2011).

${ }^{156}$ M. Steiner, S. P. Philipps, M. Hermle, A. W. Bett, and F. Dimroth, "Validated front contact grid simulation for GaAs solar cells under concentrated sunlight," Prog. Photovoltaics 19(1), 73-83 (2010).

${ }^{157}$ M. Wiesenfarth, M. Steiner, J. Wolf, T. Schmidt, and A. W. Bett, "Investigation of different Fresnel lens designs and methods to determine the optical efficiency," AIP Conf. Proc. 1616, 97-101 (2014). 
${ }^{158}$ M. Victoria, S. Askins, R. Herrero, I. Antón, and G. Sala, "Assessment of the optical efficiency of a primary lens to be used in a CPV system," Sol. Energy 134, 406-415 (2016).

${ }^{159}$ M. Steiner, P. Kiefel, G. Siefer, M. Wiesenfarth, F. Dimroth, R. Krause, A. Gombert, and A. W. Bett, "CPV module design optimization for advanced multi-junction solar cell concepts," AIP Conf. Proc. 1679, 100005 (2015)

${ }^{160}$ G. Siefer, C. Baur, M. Meusel, F. Dimroth, A. W. Bett, and W. Warta, "Influence of the simulator spectrum on the calibration of multi-junction solar cells under concentration," in Proceedings of the 29th IEEE Photovoltaic Specialists Conference, Hyatt Regency New Orleans, New Orleans, Louisiana, 19-24 May 2002 (Institute of Electrical and Electronics Engineers, Piscataway, N.J., 2002), pp. 836-839.

${ }^{161}$ J. Jaus, R. Hue, M. Wiesenfarth, G. Peharz, and A. W. Bett, "Thermal management in a passively cooled concentrator photovoltaic module," in Proceedings of the 23rd European Photovoltaic Solar Energy Conference (WIP-Renewable Energies, München, Germany, 2008), pp. 832-836.

${ }^{162}$ J. Jaus, U. Fleischfresser, G. Peharz, F. Dimroth, H. Lerchenmüller, and A. W. Bett, "Heat sink substrates for automated assembly of concentrator modules," in Proceedings of the 21st European Photovoltaic Solar Energy Conference (2006), pp. 2120-2123.

${ }^{163}$ J. S. Foresi, L. Yang, P. Blumenfeld, J. Nagyvary, G. Flynn, and D. Aiken, "EMCORE receivers for CPV system development," in Proceedings of the 35th IEEE Photovoltaic Specialists Conference (PVSC) (IEEE, Piscataway, NJ, 2010), pp. 209-212.

${ }^{164} \mathrm{M}$. Wiesenfarth, S. Gamisch, T. Dorsam, and A. W. Bett, "Challenges for thermal management and production technologies in concentrating photovoltaic (CPV) modules," in Proceedings of 5th Electronic SystemIntegration Technology Conference (ESTC 2014) (IEEE, Piscataway, NJ, 2014), pp. 1-4

${ }^{165} \mathrm{M}$. Wiesenfarth, S. Thaller, J. Jaus, F. Eltermann, M. Passig, and A. W. Bett, "Investigations on interconnection technologies for CPV systems," in Proceedings of the 25th European Photovoltaic Solar Energy Conference and Exhibition/5th World Conference on Photovoltaic Energy Conversion (2010), pp. 147-151.

${ }^{166}$ S. Askins and G. S. Pano, "CPV modules," in Handbook of Concentrator Photovoltaic Technology, edited by C. Algora and I. Rey-Stolle (Wiley, Chichester, West Sussex, United Kingdom, 2016), pp. 339-405.

${ }^{167}$ W. G. Anderson, P. M. Dussinger, D. Sarraf, and S. Tamanna, "Heat pipe cooling of concentrating photovoltaic cells," in Proceedings of the 33rd IEEE Photovoltaic Specialists Conference (IEEE, 2008), pp. 1-6.

${ }^{168} \mathrm{~K}$. Nishioka, Y. Ota, K. Tamura, and K. Araki, "Heat reduction of concentrator photovoltaic module using high radiation coating," Surf. Coat. Technol. 215, 472-475 (2013).

${ }^{169}$ H. Chayet, I. Lozovsky, O. Kost, R. Löckenhoff, and K. D. Rasch, "High efficiency, low cost parabolic dish system for cogeneration of electricity and heat," AIP Conf. Proc. 1277, 175-178 (2010).

${ }^{170}$ M. Schmitz, N. Wiik, G. Ambrosetti, A. Pedretti, S. Paredes, P. Ruch, B. Michel, and A. Steinfeld, "A 6-focus high-concentration photovoltaicthermal dish system," Sol. Energy 155, 445-463 (2017).

${ }^{171}$ T. Stalcup, R. Angel, A. Geary, F. Sodari, M. Rademacher, A. Whiteside, J. Will, N. Didato, and P. Strittmatter, "On-grid performance of REhnu's 8-mirror CPV-T tracker," in Proceedings of 13th International Conference on Concentrator Photovoltaics (2017), p. 20012.

${ }^{172}$ H. Hayden, P. Thomas, N. Fette, Z. Farkas, M. Bading, B. Stone, M. Miner, O. Stickroth, N. Bagewadi, M. Romero, B. Sonuparlak, R. Eichholz, M. Ziegler, and E. Pawlowski, "CPV semi-dense array design for dish and tower collectors," Proc. SPIE 8468, 84680I (2012).

${ }^{173}$ C. L. Tilford, R. A. Sinton, R. M. Swanson, R. A. Crane, and P. Verlinden, "Development of a $10 \mathrm{~kW}$ reflective dish PV system," in Proceedings of the 23rd IEEE Photovoltaic Specialists Conference, Galt House Hotel, Louisville, KY, 10-14 May 1993 (IEEE, Piscataway, 1993), pp. 1222-1227.

${ }^{174}$ J. B. Lasich, A. Cleeve, N. Kaila, G. Gnakas, M. Timmons, T. Venkatasubramanian, T. Colpitts, and J. Hills, "Close-packed cell array for dish concentrators," in Proceedings of the 1st World Conference on Photovoltaic Energy Conversion (1994), Vol. 2, pp. 1938-1941.

${ }^{175} \mathrm{H}$. Helmers, A. W. Bett, J. Parisi, and C. Agert, "Modeling of concentrating photovoltaic and thermal systems," Prog. Photovoltaics 22(4), 427-439 (2014).

${ }^{176}$ M. Wiesenfarth, M. Steiner, H. Helmers, G. Siefer, E. Oliva, F. Dimroth, G. Shelef, G. Polonsky, Y. Flitsanov, A. Kribus, and A. W. Bett, "Frontside interconnected large area concentrator cells for compact concentrator modules," AIP Conf. Proc. 1477, 204-207 (2012).
${ }^{177}$ J. R. Kukulka and D. R. Lillington, "Solar cell structure with by-pass diode and wrapped front-side diode interconnection," U.S. patent 7,335,835 B2 (8 November 2002).

${ }^{178}$ E. Oliva, T. Salvetat, C. Jany, R. Thibon, H. Helmers, M. Steiner, M. Schachtner, P. Beutel, V. Klinger, J.-S. Moulet, and F. Dimroth, "GaInP/ AlGaAs metal-wrap-through tandem concentrator solar cells," Prog. Photovoltaics 25(7), 477-483 (2017).

${ }^{179}$ S. van Riesen, R. Löckenhoff, F. Dimroth, and A. W. Bett, "GaAs-monolithically interconnected modules (MIMs) with an efficiency above 20\%," in Proceedings of the 19th European Photovoltaic Solar Energy Conference (2004), pp. 150-153.

${ }^{180}$ R. Loeckenhoff, G. Dibowski, F. Dimroth, M. Meusel, S. Riesen, and A. W. Bett, "1000 sun, compact receiver based on monolithic interconnected modules (MIMS)," in Proceedings of the 4th World Conference on Photovoltaic Energy Conversion (Institute of Electrical and Electronics Engineers, Piscataway, NJ, 2006), pp. 737-740.

${ }^{181}$ H. Helmers, O. Oliva, W. Bronner, F. Dimroth, and A. W. Bett, "Advanced processing techniques used for the development of dualjunction monolithic interconnected modules," AIP Conf. Proc. 1277, 39-42 (2010).

${ }^{182}$ T. Schlegl, P. Abbott, T. Aicher, F. Dimroth, G. Siefer, R. Szolak, and A. W. Bett, "GaSb based PV modules for a TPV generator system," in Proceedings of the 20th European Photovoltaic Solar Energy Conference (WIP Munich, Munich, Germany, 2005), pp. 258-261.

${ }^{183}$ M. Wiesenfarth, H. Helmers, S. P. Philipps, M. Steiner, and A. W. Bett, "Advanced concepts in concentrating photovoltaics (CPV)," in Proceedings of the 27th European Photovoltaic Solar Energy Conference and Exhibition (2012), pp. 11-15.

${ }^{184}$ H. Helmers, A. Boos, F. Jetter, A. Heimsath, M. Wiesenfarth, A. W. Bett, F. Dimroth, S. R. Kurtz, and G. Sala, "Outdoor test setup for concentrating photovoltaic and thermal (CPVT) systems," AIP Conf. Proc. 1407, 175-179 (2011).

${ }^{185}$ G. Polonsky, G. Shelef, Y. Flitsanov, M. Wiesenfarth, M. Steiner, H. Helmers, A. W. Bett, and A. Kribus, "Efficiency of dense array CPVT module with front-side interconnected cells," AIP Conf. Proc. 1556, 180-184 (2013).

${ }^{186}$ R. Löckenhoff, F. Dimroth, E. Oliva, A. Ohm, J. Wilde, D. Faiman, S. Biryukov, V. Melnichak, S. Kabalo, D. Bokobza, and A. W. Bett, "Development, characterisation and 1000 suns outdoor tests of GaAs monolithic interconnected module (MIM) receivers," Prog. Photovoltaics 16(2), 101-112 (2008).

${ }^{187}$ W. Escher, T. Brunschwiler, B. Michel, and D. Poulikakos, "Experimental investigation of an ultrathin manifold microchannel heat sink for liquid-cooled chips," J. Heat Transfer 132(8), 081402 (2010).

${ }^{188}$ Y. Flitsanov and A. Kribus, "A cooler for dense-array CPV receivers based on metal foam," Sol. Energy 160, 25-31 (2018).

${ }^{189}$ A. Royne and C. J. Dey, "Design of a jet impingement cooling device for densely packed PV cells under high concentration,” Sol. Energy 81(8), 1014-1024 (2007).

${ }^{190}$ J. Barrau, A. Perona, A. Dollet, and J. Rosell, "Outdoor test of a hybrid jet impingement/micro-channel cooling device for densely packed concentrated photovoltaic cells," Sol. Energy 107, 113-121 (2014).

${ }^{191}$ A. Royne, C. J. Dey, and D. R. Mills, "Cooling of photovoltaic cells under concentrated illumination. A critical review," Sol. Energy Mater. Sol. Cells 86(4), 451-483 (2005).

${ }^{192}$ R. Angel, T. Connors, W. Davison, M. Rademacher, B. Coughenour, G. Butel, D. Lesser, F. Dimroth, S. R. Kurtz, G. Sala, and A. W. Bett, "Development and on-sun performance of dish-based HCPV," AIP Conf. Proc. 1407, 34-37 (2011)

${ }^{193}$ T. Stalcup, J. R. P. Angel, B. Coughenour, B. Wheelwright, T. Connors, W. Davison, D. Lesser, J. Elliott, and J. Schaefer, "On-sun performance of an improved dish-based HCPV system," Proc. SPIE 8468, 84680F (2012).

${ }^{194}$ B. Deepak, "Central receiver solar power systems: Architecture and controls methods," U.S. patent 2009/0,178,668A1 (2007).

${ }^{195}$ M. Steiner, E. E. Perl, J. Simon, D. J. Friedman, N. Jain, P. Sharps, C. McPheeters, and M. L. Lee, "AlGaInP/GaAs tandem solar cells for power conversion at $400{ }^{\circ} \mathrm{C}$ and high concentration," AIP Conf. Proc. 1881, 40007 (2017).

${ }^{196}$ K. Nishioka, T. Takamoto, T. Agui, M. Kaneiwa, Y. Uraoka, and T. Fuyuki, "Annual output estimation of concentrator photovoltaic systems using high-efficiency InGaP/InGaAs/Ge triple-junction solar cells based on experimental solar cell's characteristics and field-test meteorological data," Sol. Energy Mater. Sol. Cells 90(1), 57-67 (2006). 
${ }^{197}$ E. F. Fernández, G. Siefer, M. Schachtner, A. J. García Loureiro, and P. Pérez-Higueras, "Temperature coefficients of monolithic III-V triplejunction solar cells under different spectra and irradiance levels," AIP Conf. Proc. 1477, 189-193 (2012).

${ }^{198}$ G. Siefer and A. W. Bett, "Analysis of temperature coefficients for III-V multi-junction concentrator cells," Prog. Photovoltaics 22(5), 515-524 (2014).

${ }^{199}$ H. Helmers, M. Schachtner, and A. W. Bett, "Influence of temperature and irradiance on triple-junction solar subcells," Sol. Energy Mater. Sol. Cells 116, 144-152 (2013).

${ }^{200}$ N. Núñez, J. R. González, M. Vazquez, C. Algora, and P. Espinet, "Evaluation of the reliability of high concentrator GaAs solar cells by means of temperature accelerated aging tests," Prog. Photovoltaics 21(5), 1104-1113 (2013).

${ }^{201}$ M. Wiesenfarth, S. Gamisch, H. Kraus, and A. W. Bett, "Investigations on 3-dimensional temperature distribution in a FLATCON-Type CPV module," AIP Conf. Proc. 1556, 189-193 (2013).

${ }^{202}$ J. Jaus, "Entwicklung von photovoltaischen Konzentratormodulen mit Fresnel-Linsen und reflektiver Sekundäroptik," Ph.D. dissertation (Albert-Ludwigs-Universität, 2009).

${ }^{203}$ S. Ellis, "Impact of environmental hazards on internal soiling within concentrator photovoltaic (CPV) modules," AIP Conf. Proc. 1616, 246-249 (2014).

${ }^{204}$ V. D. Rumyantsev, A. Chalov, E. Ionova, V. Larionov, and V. M. Andreev, "Concentrator PV modules with multi-junction cells and primary/secondary refractive optical elements," in Proceedings of the 19th European Photovoltaic Solar Energy Conference (2004), pp. 2090-2093.

${ }^{205}$ P. Benitez, J. Carlos Miñano, M. Hernandez, A. Cvetkovic, and O. Dross, "XR: A high-performance photovoltaic concentrator," in Proceedings of 4th International Conference on Solar Concentrators for the Generation of Electricity or Hydrogen (El Escorial, Spain, 2007).

${ }^{206}$ V. Diaz, J. Alonso, M. Hernandez, J. L. Alvarez, M. Labrador, J. Blen, R. Mohedano, P. Benitez, J. C. Minano, W. Preuss, and A. Gessenharter, "Progress in the manufacture of ultra flat optics for very high concentration flat panels," in Proceedings of the 29th IEEE Photovoltaic Specialists Conference, Hyatt Regency New Orleans, New Orleans, Louisiana, 19-24 May 2002 (Institute of Electrical and Electronics Engineers, Piscataway, N.J., 2002), pp. 1580-1583.

${ }^{207}$ V. Diaz, J. L. Alvarez, C. Mateos, and E. Rodriguez, "PV systems based on very high concentration. Isofoton approach for reaching the market," in Proceedings of the 22nd European Photovoltaic Solar Energy Conference and Exhibition (2007), pp. 93-96.

${ }^{208}$ J. P. Morgan, "Light-guide solar panel and method of fabrication thereof," U.S. patent 7,873,257 B2 (2008).

${ }^{209}$ V. C. Coffey, "Solar concentrators. Using optics to boost photovoltaics," Opt. Photonics News 22(1), 22 (2011).

${ }^{210}$ F. Eltermann, M. Wiesenfarth, G. Siefer, J. Wilde, and A. W. Bett, "The effects of accelerated aging tests on metamorphic III-V concentrator solar cells mounted on substrates," in Proceedings of the 26th European Photovoltaic Solar Energy Conference and Exhibition (2011), pp. $163-168$.

${ }^{211}$ F. Eltermann, L. Ziegler, M. Wiesenfarth, J. Wilde, and A. W. Bett, "Performance and failure analysis of concentrator solar cells after intensive stressing with thermal, electrical, and combined load," AIP Conf. Proc. 1881, 50002 (2017).

${ }^{212}$ P. Benitez, J. C. Miñano, and R. Alvarez, "Photovoltaic concentrator with auxiliary cells collecting diffuse radiation," U.S. patent 2010/0,126,556 A1 (20 November 2009).

${ }^{213}$ K.-T. Lee, Y. Yao, J. He, B. Fisher, X. Sheng, M. Lumb, L. Xu, M. A. Anderson, D. Scheiman, S. Han, Y. Kang, A. Gumus, R. R. Bahabry, J. W. Lee, U. Paik, N. D. Bronstein, A. P. Alivisatos, M. Meitl, S. Burroughs, M. M. Hussain, J. C. Lee, R. G. Nuzzo, and J. A. Rogers, "Concentrator photovoltaic module architectures with capabilities for capture and conversion of full global solar radiation," Proc. Natl. Acad. Sci. U. S. A. 113(51), E8210-E8218 (2016).

${ }^{214} \mathrm{~N}$. Yamada and D. Hirai, "Maximization of conversion efficiency based on global normal irradiance using hybrid concentrator photovoltaic architecture," Prog. Photovoltaics 24(6), 846-854 (2016).

${ }^{215}$ M. Martínez, D. Sánchez, F. Rubio, E. F. Fernández, F. Almonacid, N. Abela, T. Zech, and T. Gerstmaier, "CPV power plants," in Handbook of Concentrator Photovoltaic Technology, edited by C. Algora and I. ReyStolle (Wiley, Chichester, West Sussex, United Kingdom, 2016), pp. 433-490.
${ }^{216}$ J. F. Martinez, M. Steiner, M. Wiesenfarth, and F. Dimroth, "4-terminal CPV module capable of converting global normal irradiance into electricity," in Proceedings of 14th International Conference on Concentrator Photovoltaic Systems (American Institute of Physics, Melville, N.Y., 2018).

${ }^{217}$ N. Hayashi, M. Terauchi, Y. Aya, S. Kanayama, H. Nishitani, T. Nakagawa, and M. Takase, "Thin concentrator photovoltaic module with micro-solar cells which are mounted by self-align method using surface tension of melted solder," AIP Conf. Proc. 1881, 80005 (2017).

${ }^{218}$ K. Ghosal, B. Fisher, D. Lilly, J. Gabriel, S. Seel, and S. Burroughs, "Ultrahigh efficiency HCPV modules and systems," IEEE J. Photovoltaics 6(5), 1360-1365 (2016).

${ }^{219}$ N. Hayashi, A. Matsushita, D. Inoue, M. Matsumoto, T. Nagata, H. Higuchi, Y. Aya, and T. Nakagawa, "Nonuniformity sunlight-irradiation effect on photovoltaic performance of concentrating photovoltaic using microsolar cells without secondary optics," IEEE J. Photovoltaics 6(1), 350-357 (2016).

${ }^{220}$ T. B. Stellwag, P. E. Dodd, M. S. Carpenter, M. S. Lundstrom, R. F. Pierret, M. R. Melloch, E. Yablonovitch, and T. J. Gmitter, "Effects of perimeter recombination on GaAs-based solar cells," in Proceedings of the 21st IEEE Photovoltaic Specialists Conference (IEEE, 1990), pp. $442-447$.

${ }^{221}$ B. Furman, E. Menard, A. Gray, M. Meitl, S. Bonafede, D. Kneeburg, K. Ghosal, R. Bukovnik, W. Wagner, J. Gabriel, S. Seel, and S. Burroughs, "A high concentration photovoltaic module utilizing micro-transfer printing and surface mount technology," in Proceedings of the 35th IEEE Photovoltaic Specialists Conference (PVSC) (IEEE, Piscataway, NJ, 2010), pp. 475-480.

${ }^{222}$ E. E. Kuran, Magnetic Self-Assembly with Unique Rotational Alignment (Delft University of Technology, 2015).

${ }^{223}$ P. Y. Maeda, J. P. Lu, G. L. Whiting, D. K. Biegelsen, S. Raychaudhuri, R. Lujan, J. Veres, E. M. Chow, V. Gupta, G. N. Nielson, and S. Paap, "Micro chiplet printer for micro-scale photovoltaic system assembly," in Proceedings of the 42nd IEEE Photovoltaic Specialist Conference (PVSC) (IEEE Service Center, Piscataway, NJ, 2015), pp. 1-6.

${ }^{224}$ J. S. Smith, M. A. Hadley, G. S. W. Craig, and P. F. Nealey, "Methods and apparatuses for improved flow in performing fluidic self-assembly," U.S. patent 6,527,964 (2 November 2003).

${ }^{225}$ Alien Technology Corp., "White paper - Fluidic self-assembly" (1999).

${ }^{226}$ C. Domínguez, N. Jost, S. Askins, M. Victoria, and I. Antón, “A review of the promises and challenges of micro-concentrator photovoltaics," AIP Conf. Proc. 1881, 80003 (2017).

${ }^{227}$ Deutsches Institut für Normung, Konzentrator-Photovoltaik (CPV) Leistungsmessung - Teil 1: Standardprüfbedingungen (IEC 626701:2013); Deutsche Fassung EN 62670-1:2014 (62670-1) (Beuth Verlag, Berlin).

${ }^{228}$ G. Peharz, G. Siefer, and A. W. Bett, "A simple method for quantifying spectral impacts on multi-junction solar cells," Sol. Energy 83(9), 1588-1598 (2009).

${ }^{229}$ R. Núñez, C. Domínguez, S. Askins, M. Victoria, R. Herrero, I. Antón, and G. Sala, "Determination of spectral variations by means of component cells useful for CPV rating and design," Prog. Photovoltaics 24(5), 663-679 (2016).

${ }^{230}$ M. Steiner, M. Muller, G. Siefer, and A. W. Bett, "Component cell-based restriction of spectral conditions and the impact on CPV module power rating," Prog. Photovoltaics 26(5), 351-358 (2018).

${ }^{231}$ C. Domínguez, I. Antón, and G. Sala, "Solar simulator for concentrator photovoltaic systems," Opt. Express 16(19), 14894-14901 (2008).

${ }^{232}$ G. Peharz, J. P. F. Rodriguez, G. Siefer, and A. W. Bett, "Indoor characterization of CPV modules at Fraunhofer ISE," in Proceedings of the 5th International Conference on Solar Concentrators for the Generation of Electricity (2008).

${ }^{233}$ V. D. Rumyantsev, N. A. Sadchikov, A. E. Chalov, E. A. Ionova, D. J. Friedman, and G. S. Glenn, "Terrestrial concentrator PV modules based on GaInP/GaAs/Ge TJ cells and minilens panels," in Proceedings of the 4th World Conference on Photovoltaic Energy Conversion (Institute of Electrical and Electronics Engineers, Piscataway, NJ, 2006), pp. 632-635

${ }^{234}$ C. Rapp, V. Straub, D. W. van Rooyen, W. Y. Thor, G. Siefer, and A. W. Bett, "Optical investigation of a sun simulator for concentrator PV applications," Opt. Express 23(19), A1270-A1279 (2015).

${ }^{235}$ C. Domínguez, R. Herrero, and I. Antón, "Characterization of CPV modules and receivers," in Handbook of Concentrator Photovoltaic 
Technology, edited by C. Algora and I. Rey-Stolle (Wiley, Chichester, West Sussex, United Kingdom, 2016), pp. 639-684.

${ }^{236}$ C. Dominguez, S. Askins, I. Anton, and G. Sala, "Characterization of five CPV module technologies with the Helios 3198 solar simulator," in Proceedings of the 34th IEEE Photovoltaic Specialists Conference (PVSC) (IEEE, 2009), pp. 1004-1008.

${ }^{237}$ A. Plesniak and V. Garboushian, "A profile of the Amonix $7700 \mathrm{CPV}$ solar power system," in Proceedings of IEEE Electrical Power \& Energy Conference (2011), Vol. 8108, p. 810803.

${ }^{238}$ C. Rapp, M. Steiner, G. Siefer, and A. W. Bett, "Stepwise measurement procedure for the characterization of large-area photovoltaic modules," Prog. Photovoltaics 23(12), 1867-1876 (2015).

${ }^{239}$ M. Muller, S. R. Kurtz, M. Steiner, and G. Siefer, "Translating outdoor CPV I-V measurements to a CSTC power rating and the associated uncertainty," Prog. Photovoltaics 23, 1557-1571 (2015).

${ }^{240}$ M. Steiner, T. Gerstmaier, and A. W. Bett, "Concentrating photovoltaic systems," in The Performance of Photovoltaic (PV) Systems. Modelling, Measurement and Assessment, edited by N. Pearsall (Woodhead Publishing, Cambridge, 2017), pp. 297-320.

${ }^{241}$ European Photovoltaic Technology Platform, A Strategic Research Agenda for Photovoltaic Solar Energy Technology, 2nd ed. (2011), see http://www. etip-pv.eu/publications/strategic-research-agenda-implementation-plan.html.

${ }^{242} \mathrm{C}$. Gueymard, "A simple model of the atmospheric radiative transfer of sunshine" (Professional Paper FSEC-PF-270-95, Florida Solar Energy Center, 1679 Clearlake Rd., Cocoa, FL 32922, 1995).

${ }^{243} \mathrm{C}$. Gueymard, "Parameterized transmittance model for direct beam and circumsolar spectral irradiance," Sol. Energy 71(5), 325-346 (2001).

${ }^{244}$ N. J. Ekins-Daukes, T. R. Betts, Y. Kemmoku, K. Araki, H. S. Lee, R. Gottschalg, M. B. Boreland, D. G. Infield, and M. Yamaguchi, "Syracuse - A multi-junction concentrator system computer model," in Proceedings of the 31st IEEE Photovoltaic Specialists Conference (IEEE, 2005), pp. 651-654.

${ }^{245}$ M. Steiner, G. Siefer, T. D. Hornung, G. Peharz, and A. W. Bett, "YieldOpt, a model to predict the power output and energy yield for concentrating photovoltaic modules," Prog. Photovoltaics 23, 385-397 (2015).

${ }^{246}$ J. Leloux, E. Lorenzo, B. Garcia-Domingo, J. Aguilera, and C. A. Gueymard, "A bankable method of assessing the performance of a CPV plant,” Appl. Energy 118, 1-11 (2014).
${ }^{247}$ G. S. Kinsey, K. W. Stone, J. Brown, and V. Garboushian, "Energy prediction of amonix CPV solar power plants," Prog. Photovoltaics 19, 794-796 (2011).

${ }^{248}$ C. Cameron, C. Crawford, J. Foresi, D. King, R. McConnell, D. Riley, A. Sahm, and J. S. Stein, "Performance model assessment for multi-junction concentrating photovoltaic systems," AIP Conf. Proc. 1277, 290-293 (2010).

${ }^{249}$ T. Gerstmaier, S. van Riesen, A. Gombert, A. Mermoud, T. Lejeune, and E. Duminil, "Software modeling of FLATCON ${ }^{\circledR}$ CPV systems," AIP Conf. Proc. 1277, 183-186 (2010).

${ }^{250}$ T. Gerstmaier, M. Gomez, A. Gombert, A. Mermoud, and T. Lejeune, "Validation of the PVSyst performance model for the concentrix CPV technology," in Proceedings of IEEE Electrical Power \& Energy Conference (2011), Vol. 1407, pp. 366-369.

${ }^{251}$ R. Jan, "Accuracy of meteonorm 7.1.6," in paper presented at $\mathrm{TueV}$ Modelling Workshop, 2015.

${ }^{252}$ S. R. Kurtz, M. Muller, D. Jordan, K. Ghosal, B. Fisher, P. Verlinden, J. Hashimoto, and D. Riley, "Key parameters in determining energy generated by CPV modules," Prog. Photovoltaics 23(10), 1250-1259 (2015).

${ }^{253}$ A. Gombert, "From 0.01 to $44 \mathrm{MWp}$ with concentrix technology," AIP Conf. Proc. 1766, 030001 (2016).

${ }^{254}$ M. Martinez, F. Rubio, G. Sala, D. Pachon, A. W. Bett, G. Siefer, M. Vetter, A. Schies, J. Wachtel, A. Gombert, J. Wullner, V. Diaz, M. A. Vazquez, F. A. Abulfotuh, K. Fetyan, A. El Moussaoui, S. Mansouri, K. Loudiyi, H. Darhmaoui, and T. Mrabti, "CPV plants data analysis. ISFOC and NACIR projects results," AIP Conf. Proc. 1477, 323-326 (2012).

${ }^{255} \mathrm{P}$. J. Verlinden and J. B. Lasich, "Energy rating of concentrator PV systems using multi-junction III-V solar cells," in Proceedings of the 33rd IEEE Photovoltaic Specialists Conference (IEEE, 2008), pp. 373-378.

${ }^{256}$ M. Muller, D. Jordan, and S. R. Kurtz, "Degradation analysis of a CPV module after six years on-Sun,” AIP Conf. Proc. 1679, 20004 (2015).

${ }^{257}$ J. Jaus, G. Peharz, A. Gombert, J. P. F. Rodriguez, F. Dimroth, F. Eltermann, O. Wolf, M. Passig, G. Siefer, A. Hakenjos, S. v. Riesen, and A. W. Bett, "Development of FLATCON ${ }^{\circledR}$ modules using secondary optics," in Proceedings of the 34th IEEE Photovoltaic Specialists Conference (PVSC) (IEEE, 2009), pp. 1931-1936.

${ }^{258}$ G. Peharz and F. Dimroth, "Energy payback time of the high-concentration PV system FLATCON ${ }^{\circledR}$," Prog. Photovoltaics 13(7), 627-634 (2005).

${ }^{259}$ V. Fthenakis, "Life cycle analysis of CPV systems," in Handbook of Concentrator Photovoltaic Technology, edited by C. Algora and I. Rey-Stolle (Wiley, Chichester, West Sussex, United Kingdom, 2016), pp. 685-704. 